
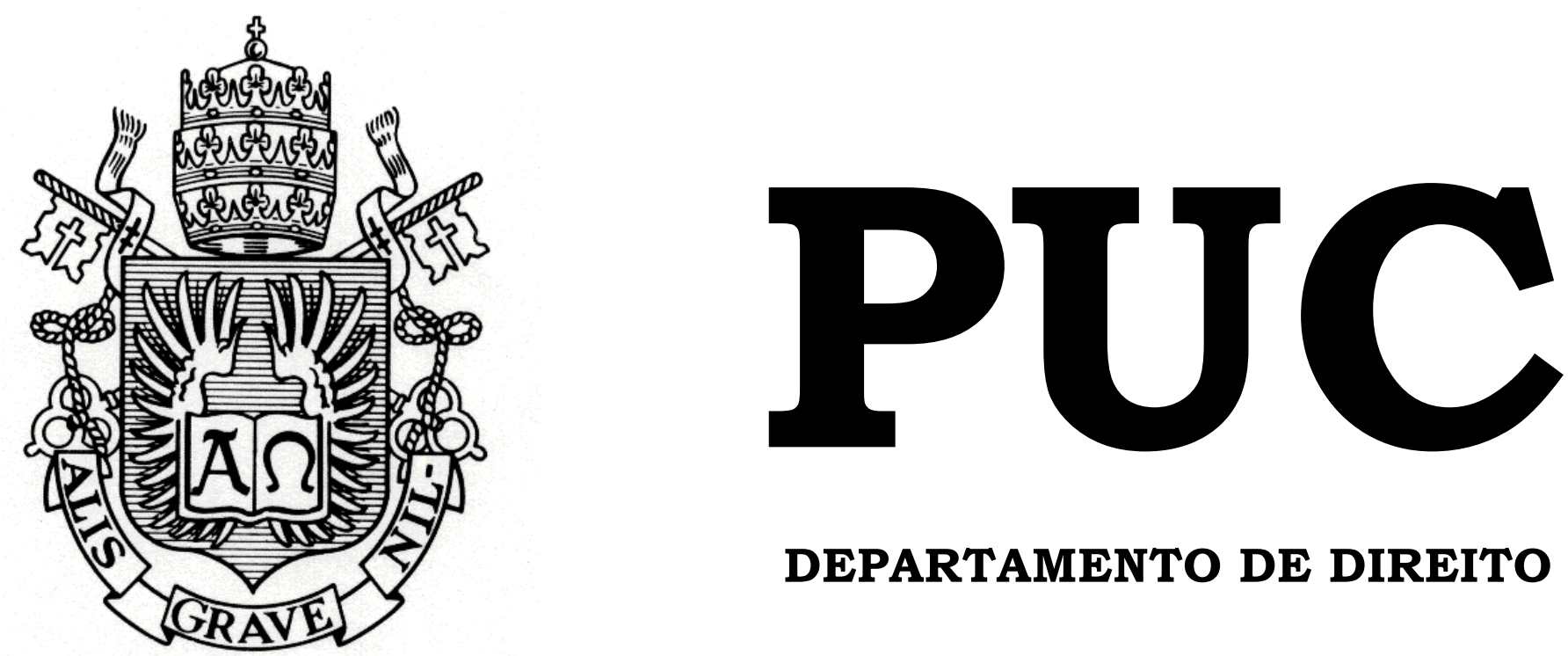

DEPARTAMENTO DE DIREITO

\title{
A AUTONOMIA NO DIREITO PRIVADO BRASILEIRO E A LEI DE ARBITRAGEM
}

por

GABRIEL FERREIRA SOARES DE BRITO

ORIENTADOR(A): Daniela Trejos Vargas

2012.1

PONTIFÍCIA UNIVERSIDADE CATÓLICA DO RIO DE JANEIRO

RUA MARQUÊS DE SÃO VICENTE, 225 - CEP 22453-900

RIO DE JANEIRO - BRASIL 


\title{
A AUTONOMIA NO DIREITO PRIVADO BRASILEIRO E A LEI DE ARBITRAGEM
}

\author{
por \\ GABRIEL FERREIRA SOARES DE BRITO
}

Monografia

apresentada

ao

Departamento de Direito da Pontificia Universidade Católica do Rio de Janeiro (PUC-Rio) para a obtenção do Título de Bacharel em Direito.

Orientador(a): Daniela Trejos Vargas 
Ao Deus de toda graça. Dono e doador da verdadeira liberdade. 
"Gratidão é o amor contemplando o passado", diz o poeta. E sou agraciado por poder agradecer à pessoas tão valiosas, verdadeiras penas de Deus na escrita de minha vida.

Agradeço à minha orientadora, Profa. Daniela Vargas, tão solícita e disposta diante das minhas perguntas (e e-mails tarde da noite!). Obrigado pelo tempo e atenção com meu trabalho.

Aos preciosos amigos de minha comunidade de fé, a Igreja Presbiteriana do Jardim Guanabara, obrigado pelo incentivo constante, ânimo e orações. Tê-los em minha vida tão intensamente faz de mim um ser humano melhor.

À minha doce Bruna, meu amor, obrigado pelo encorajamento, cuidado e principalmente, paciência. Construiremos, pela graça de nosso Deus, uma linda história.

Por fim, mas não por último, minha família. Não tenho palavras para lhes dizer o quanto vocês são importantes em minha vida. Wladymir Filho e Lucas, vocês são meus melhores amigos. Obrigado por terem me aguentado falando tanto de arbitragem! Wla, em especial te agradeço por sempre me incentivar e me aconselhar nos projetos e ideias. Meus pais, vocês são meus heróis! Obrigado por tudo que fizeram por mim até hoje, e espero que nosso Deus me ajude a ser o filho que vocês merecem ter. Sou imensamente grato a Deus por tê-los. Sou grato, igualmente, pela verve acadêmica que é tão importante em nossa família. Trabalho de vocês. Por fim, meus pais e heróis, diz-se que enxergamos o mundo sobre os ombros de gigantes que nos antecederam. Pois bem, vocês são os meus gigantes. Amo vocês.

Soli Deo Gloria. 
Resumo: A autonomia representa um valor inerente à dignidade humana $\mathrm{e}$ recebe a tutela do ordenamento jurídico na cláusula constitucional da liberdade (art. $5^{\circ}$, II da $\mathrm{CF} / 88$ ). Chama-se autonomia privada a liberdade aplicada às relações entre particulares. Em uma análise crítica, percebe-se que o tratamento da autonomia privada sofreu diversas alterações de acordo com o momento histórico, revelando um "movimento pendular", ora com limites mais amplos, ora restritos. A internacionalização da vida justifica o exame da autonomia de forma interdisciplinar, tanto no direito interno quanto internacional. Nestes dois ramos do direito, a arbitragem (Lei $\mathrm{n}$. 9.307/96) representa a consagração da autonomia privada, que se no plano interno, antes de limitar a vontade privada, qualifica-a, dando contornos objetivos e protetivos, no plano internacional representa a superação no direito pátrio da polêmica discussão acerca da regra de conexão aplicável aos contratos internacionais, consagrando a livre escolha das partes.

Abstract: Autonomy is an inherent value to human dignity and receives legal protection by the constitutional provision of freedom (art. 5, CF/88 II). It's called "private autonomy" such freedom applied to relations between individuals. In a critical analysis, it is clear that the treatment of private autonomy was altered according to the historical moment, revealing a "pendulum movement", sometimes with wider limits, sometimes restricted. Life's internationalization justifies private autonomy's interdisciplinary examination: private and international private law. In these two branches of the Law, the Arbitration Act (no. 9.307/96) represents the consecration of parties' autonomy. Hence, internally, it represents not a limitation the private will, but a qualification, giving contours and protective goals to it. Whereas, at the Conflict of Laws' level, represents the overcoming to Brazilian controversial discussion on the conflict rule applied to international contracts, ensuring the parties' free choice. 
Palavras-chave: Direito Privado; história do direito; autonomia privada; Arbitragem; Direito civil-constitucional; tutela da boa-fé objetiva; lei aplicável; autonomia da vontade; Lei 9.307/1996; arbitragem interna e internacional. 


\section{Sumário}

Introdução

1. A autonomia no Direito Privado interno...........................................14

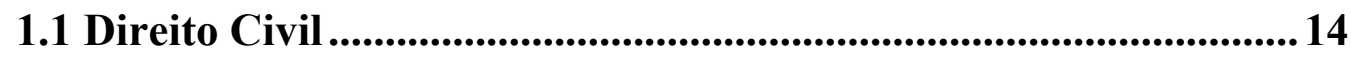

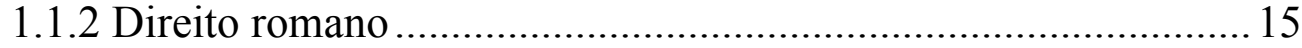

1.1.3 Século XIX e a "autonomia da vontade" ..................................... 16

1.1.4 A mudança de paradigma e a publicização do Direito Civil .......22

1.1.5 O Código Civil de 1916, o direito civil-constitucional e o Código

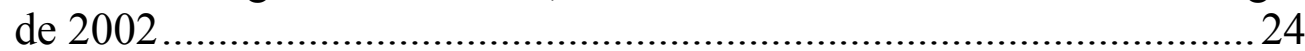

2. A vontade no Direito Internacional Privado.......................................34

2.1 Evolução da doutrina comparada .................................................... 35

2.2 Autonomia no DIPr pátrio e sua evolução ........................................ 46

3. $\mathrm{O}$ instituto da Arbitragem ......................................................................56

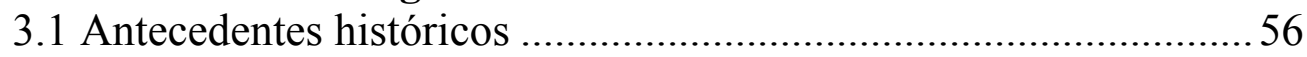

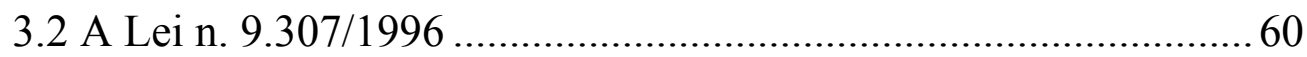

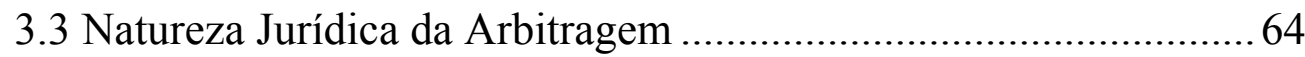

3.4 Importantes convenções ratificadas pelo Brasil................................ 68

4. Código Civil, Autonomia e Arbitragem: entre liberdade e responsabilidade ...............................................................................................70

4.1 Autonomia em arbitragem e venire contra factum proprium ........ 70

4.2 Autonomia e deveres laterais: um olhar para a confidencialidade 74

5. Autonomia privada e arbitragem no plano internacional................... 79

5.1 Autonomia e arbitragem na lei aplicável ....................................... 80

5.2 Relação entre as regras de conexão: revogação ou convivência? .. 84

$5.3 \mathrm{O}$ alcance da autonomia da vontade: arbitragem interna e

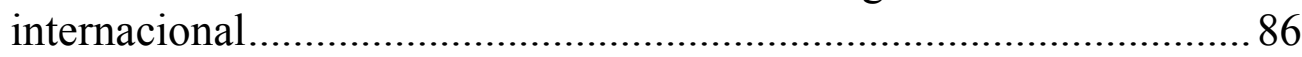

5.4 Autonomia e o limite da ordem pública......................................... 94

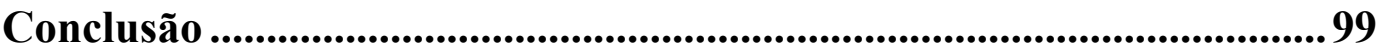

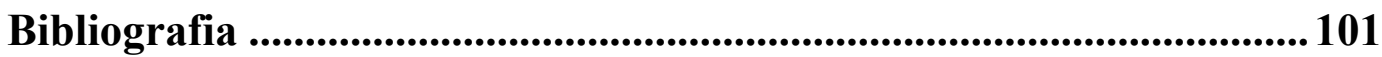




\section{Introdução}

O presente trabalho, apresentado como conclusão do curso de Direito na Pontifícia Universidade Católica do Rio de Janeiro, tem por objetivo analisar, em que pese sua brevidade dado o objeto de estudo ser tão extenso, o trato jurídico da autonomia no âmbito das relações privadas.

Diante da hodierna suavização de fronteiras, em que aquilo que é dito internacional tanto influencia, e por vezes confunde-se, com o que é dito interno, fenômeno que argutamente o professor Jacob Dolinger classificou como "internacionalização da vida", justifica-se o exame da autonomia não apenas em seus efeitos no plano interno, mas também sob os auspícios do tão importante Direito Internacional Privado.

Em feliz locução, Lauro Gama e Souza Jr., classifica o movimento do papel da autonomia da vontade como pendular. Assim o é pois ao longo do tempo este importantíssimo princípio sofreu tratamentos diversos, seja em âmbito interno, seja em sede internacional. ${ }^{2}$

O instituto da arbitragem, expressão máxima da autonomia pois retira dela sua razão, mola propulsora e fim, padeceu igualmente deste movimento pendular. Explica-se: os primórdios da arbitragem remontam a momento anterior ao Estado, em que aos particulares cabia a resolução de seus conflitos sem o aparato judicial daquele, seja por autotutela, seja por heterocomposição, forma na qual se insere a arbitragem, uma vez que esta consubstancia-se na escolha de um terceiro imparcial pelas partes em conflito para a resolução do mesmo. Com o advento do Estado, e sua consequente expansão, viu-se a opção pela arbitragem minguar.

\footnotetext{
${ }^{1}$ DOLINGER, Jacob, Direito Internacional Privado: parte geral, Rio de Janeiro: Renovar, $9^{\text {a }}$ ed., ${ }^{2}$ SOUZA JR., Lauro Gama. "Autonomia da vontade nos contratos internacionais no Direito Internacional Privado brasileiro: Uma leitura constitucional do artigo $9^{\circ}$ da Lei de Introdução ao Código Civil em favor da liberdade de escolha do direito aplicável", In: TIBURCIO, Carmen e BARROSO, Luís Roberto (Org.) "O direito internacional contemporâneo: estudos em homenagem ao professor Jacob Dolinger”, Rio de Janeiro: Renovar, 2006, p601.
} 
Todavia, o mundo de incertezas, na expressão consagrada por Natalino Irti, $^{3}$ demanda uma celeridade tal na resolução de conflitos que não mais pode ser confiada apenas ao aparato judicial. Neste diapasão, chama-se a via arbitral para suprir aquilo que a judicial não pode prover: celeridade, sigilo, previsibilidade de decisões e flexibilidade. Elementos estes tão afeitos à realidade comercial e por vezes tão faltantes na faceta judicial da jurisdição. Destarte, observa-se um crescimento exponencialmente da arbitragem no cenário mundial. Se outrora a arbitragem estava relegada quase com exclusividade às hipóteses vultosas de grandes contratos internacionais, hoje o instituto cresce em popularidade, seja na prática comercial brasileira, como na seara acadêmica.

Portanto, a análise do papel da autonomia no direito privado em suas esferas interna e internacional culmina com o instituto da arbitragem, representação até então do movimento mais ousado no sentido de possibilitar o amplo exercício da autonomia privada, representando esta, na lição de Nadia de Araujo, "verdadeira revolução no direito brasileiro". 4

Diante disso, primeiramente cabe perquirir o sentido de autonomia. Esta é intimamente ligada à ideia de liberdade, e mesmo sabedores das imensas discussões de ordem política, social e metafísica acerca do conceito desta última, podemos apresentá-la como o "poder de autodeterminação, em virtude do qual o homem escolhe por si mesmo o seu comportamento pessoal." 5 Tal comportamento, conforme assinala José Afonso da Silva, é direcionado à satisfação pessoal, a busca pela felicidade. ${ }^{6}$ E ao tomar contornos jurídicos, a liberdade tutelada pelo Direito corresponde, assim, a toda manifestação de liberdade tutelada pelo

\footnotetext{
${ }^{3}$ IRTI, Natalino Apud MORAES, Maria Celina Bodin de, "Constituição e direito civil: tendências", In: "Na medida da pessoa humana", Rio de Janeiro: Renovar, 2010, p34.

${ }^{4}$ ARAUJO, Nadia de. "Contratos internacionais: autonomia da vontade, MERCOSUL e convenções internacionais". Rio de Janeiro: Renovar, $4^{\mathrm{a}}$ ed., 2009, p121.

${ }^{5}$ RIVERO Apud SILVA, José Afonso da. "Curso de Direito Constitucional Positivo”, São Paulo: Malheiros, $26^{\mathrm{a}}$ ed., 2006, p233.

${ }^{6}$ Ibidem, p233.
} 
ordenamento jurídico. Destarte, aos particulares, conforme aponta Rosa Meireles, tal liberdade jurídica corresponde à faculdade de agir licitamente, a qual existe sempre que não haja vedação pelo ordenamento. ${ }^{7} \mathrm{~A}$ máxima

“o que não é proibido, é permitido” resume este pensamento.

Com efeito, a Carta Magna de 1988, que consagra expressamente a dignidade da pessoa humana como um dos fundamentos do Estado Democrático de Direito (art. $1^{\circ}$, III), alça a autonomia como um princípio com assento na ordem constitucional brasileira. Assim o é pois a autonomia decorre da aplicação do princípio da legalidade às relações privadas, que traz no texto do art. $5^{\circ}$, II da Constituição da República a cláusula geral de liberdade, qual seja: "ninguém será obrigado a fazer ou deixar de fazer alguma coisa senão em virtude de lei $"{ }^{8}$ Nota-se, portanto, que a cláusula geral de liberdade em nosso ordenamento expressa um claro viés negativo.

\footnotetext{
${ }^{7}$ MEIRELES, Rose Melo Vencelau. "Autonomia privada e dignidade humana". Rio de Janeiro: Renovar, 2009, p64.

8 "O art. $5^{\circ}$, II, da Constituição Federal é reconhecido como positivação do princípio da legalidade. A contrario sensu se deduz o princípio geral da liberdade." (Ibidem, p65). Acerca da cláusula geral de liberdade contida no texto constitucional, aduz em valiosa lição José Afonso da Silva, para quem o art. $5^{\circ}$, II prevê "(...) a liberdade-matriz, a liberdade-base, que é a liberdade de ação em geral, a liberdade geral de atuar, que decorre do art. $5^{\circ}$, II, da Constituição, segundo o qual ninguém será obrigado a fazer ou deixar de fazer alguma coisa senão em virtude de lei. É um modo de dizer diferente daquele de Montesquieu. Para este, a liberdade consistiria no direito de fazer tudo o que as leis permitissem. $O$ texto constitucional supra, ao contrário, prevê a liberdade de fazer, a liberdade de atuar ou liberdade de agir, como princípio. Vale dizer, o princípio é o de que todos têm a liberdade de fazer e de não fazer o que bem entender, salvo quando a lei determine em contrário." E ainda: "O art. $5^{\circ}$, II, em análise, revela duas dimensões. Uma muito clara e explícita, que consubstancia o princípio da legalidade (...). Outra, nem sempre considerada pela doutrina, que é essa regra de direito fundamental, de liberdade de ação, que estamos estudando. Por isso, esse dispositivo é um dos mais importantes do direito constitucional brasileiro, porque, além de conter a previsão da liberdade de ação (liberdade-base das demais), confere fundamento jurídico às liberdades individuais e correlaciona liberdade e legalidade. Desse extrai a ideia de que a liberdade, em qualquer de suas formas, só pode sofrer restrições por normas jurídicas preceptivas (que impõem uma conduta positiva) ou proibitivas (que impõem uma abstenção), provenientes do Poder Legislativo e elaboradas segundo o procedimento estabelecido na Constituição. Quer dizer: a liberdade só pode ser condicionada por um sistema de legalidade legítima. (...) Em dúvida, prevalece a liberdade". (SILVA, José Afonso da. Op. Cit., pp234-236). Neste sentido também: "(...) o princípio da autonomia da vontade, que permeia as relações de Direito Privado, onde, ao contrário do Direito Público, é possível fazer tudo aquilo que a lei não proíbe.” (STJ, REsp 1.070.316-SP, Rel. originária Min. Nancy Andrighi, Rel. para acórdão Min. Massami Uyeda, julgado em 9/3/2010)
} 
Em outras palavras, a liberdade como não intervenção, tal como primeiramente apregoada pelos liberais. ${ }^{9}$

Vale dizer, que a cláusula geral de liberdade goza de status de garantia individual, tamanha sua importância em nosso ordenamento, o que é reconhecido pela jurisprudência de nossa Suprema Corte. ${ }^{10}$ Ademais, falar de liberdade é falar de um valor inerente à dignidade da pessoa humana, ${ }^{11}$ uma vez que se negada a ela a liberdade de auto-regrar-se, estaria por fim reduzida a mero instrumento do Estado. Destarte, sem liberdade não há singularidade, e por conseguinte, não há de se falar em pessoa humana.

Em sede de direito privado, a liberdade jurídica tutelada pela cláusula geral do art. $5^{\circ}$, II, da Constituição da República expressa-se sob o título de autonomia privada. Tal conceito demonstra a superação do dito “dogma da vontade" imperante no séc. XIX, pela qual o subjetivismo dá lugar à vontade objetiva. ${ }^{12}$ Destarte, nas palavras do célebre Pietro Perlingieri, consiste a autonomia privada:

\footnotetext{
9 "Dentro do espírito voluntarista e individualista liberal, contudo, a ideia de autonomia assumiu contornos bem diferentes. Embora mantida a identidade entre liberdade e autonomia, o conceito de liberdade assume uma função nitidamente negativa, porém cognoscível no plano fenomenológico: a liberdade como não intervenção" (SILVA, Denis Franco. "O Princípio da autonomia: da invenção à reconstrução". In: MORAES, Maria Celina Bodin de. (coord.). "Princípios do Direito Civil Contemporâneo". Rio de Janeiro: Renovar, 2006, p139).

10 ““(...) Assim, ninguém pode negar a qualidade de preceitos fundamentais da ordem constitucional aos direitos e garantias individuais (art. $5^{\circ}$, dentre outros). Da mesma forma não se poderá deixar de atribuir essa qualidade aos demais princípios protegidos pela cláusula pétrea do art. $60, \S 4^{\circ}$, da Constituição, quais sejam, a forma federativa de Estado, a separação de Poderes e o voto direto, secreto, universal e periódico." (STF, ADPF 33 MC/PA, Rel. Min. Gilmar Mendes, dj: 29.10.2003)

${ }^{11}$ É como ensina Inocêncio Coelho, apoiando-se na lição de Miguel Reale: “(...) dizer pessoa é dizer singularidade, intencionalidade, liberdade, inovação e transcendência". (grifos no original). MENDES, Gilmar Ferreira; COELHO, Inocêncio Mártires; BRANCO, Paulo Gustavo Gonet. “Curso de Direito Constitucional”. São Paulo: Saraiva, $2^{\mathrm{a}}$ ed., 2008, p150.

${ }^{12}$ Sobre o dogma da vontade, assinala Rosa Meireles: "Foi a concepção negativa de liberdade que influenciou a concepção de que a vontade individual representava a maior expressão da liberdade do indivíduo na esfera privada e, por si só, era suficiente para impedir qualquer ingerência externa no seu conteúdo e nos seus efeitos. Isso significa que o agente tinha o poder de praticar um ato jurídico e lhe determinar o conteúdo, a forma, bem como os efeitos com a sua vontade, sem qualquer interferência externa." Sobre a mudança de concepção subjetiva para objetiva, aduz ainda a autora, apoiando-se em Francisco Amaral: "autonomia da vontade dá relevo à vontade subjetiva, psicológica, enquanto que a tese da autonomia privada destaca a vontade objetiva, que resulta na declaração ou manifestação de vontade, fonte de efeitos jurídicos.” (MEIRELES, Rosa Melo Vencelau. Op. Cit., p66-68).
} 
"poder, reconhecido ou concedido pelo ordenamento estatal a um indivíduo ou a um grupo, de determinar vicissitudes jurídicas como consequência de comportamentos - em qualquer medida livremente assumidos." 13

Diante do acima exposto, pode-se concluir por ser a autonomia privada a auto-regulamentação de interesses, sejam estes patrimoniais ou não. ${ }^{14}$ Em outras palavras, é o poder reconhecido aos particulares de regrar, por meio de atuação da sua própria vontade, as relações das quais pretendem participar, obrigando-se ao conteúdo contido nesta manifestação, em consonância com a definição apresentada por Lauro Gama Souza Jr. ${ }^{15}$ Contudo, entender que o exercício da autonomia se dá sem quaisquer limites é ferir a própria ideia de liberdade, uma vez que se demonstraria (como se demonstrou a partir do séc. XX) claramente abusivo. Destarte, a autonomia configura-se num princípio, e dada a sua característica normativa, será realizada na medida possível $^{16}$, sendo esta possibilidade (e limite) pautada na proteção da pessoa humana. ${ }^{17}$

Feitas estas considerações, apresenta-se o plano de trabalho adotado para o presente trabalho. Nos dois primeiros capítulos apresenta-se a evolução histórica no tratamento da autonomia no Direito Privado. Em âmbito interno, percorre-se dos direitos romanos, detendo-se a análise no

\footnotetext{
${ }^{13}$ PERLINGIERI, Pietro. "Perfis de Direito Civil". Rio de Janeiro: Renovar, 1997, p17. As ditas "vicissitudes jurídicas" representam os efeitos modificativos, extintivos ou constitutivos advindos de quaisquer fatos.

${ }^{14}$ MEIRELES, Rosa Melo Vencelau. Op. Cit., p74.

${ }^{15}$ SOUZA JR., Lauro Gama. Op. Cit., p614.

${ }^{16}$ Regras e princípios são categorias normativas, e segundo Robert Alexy, princípios são, assim, "normas que ordenam seja algo realizado na maior medida possível, dentro das possibilidades reais, senão também, das jurídicas". Ou seja, se caracterizam pelo fato de que podem ser cumpridos em maior ou menor grau, enquanto que as regas somente podem ser cumpridas ou não. (SILVA, Denis Franco, O princípio da autonomia: da invenção à reconstrução. In: MORAES, Maria Celina Bodin (Org.). Princípios do direito civil contemporâneo. Rio de Janeiro: Renovar, 2006, p.146)

17 "A autonomia privada, que encontra claras limitações de ordem jurídica, não pode ser exercida em detrimento ou com desrespeito aos direitos e garantias de terceiros, especialmente aqueles positivados em sede constitucional, pois a autonomia da vontade não confere aos particulares, no domínio de sua incidência e atuação, o poder de transgredir ou de ignorar as restrições postas e definidas pela própria Constituição, cuja eficácia e força normativa também se impõem, aos particulares, no âmbito de suas relações privadas, em tema de liberdades fundamentais." (STF, RE 201.819, Rel. Min. Gilmar Mendes, julgamento em 11-10-2005, Segunda Turma, DJ de 27-102006.)
} 
importante momento em que a autonomia foi dita como "autonomia da vontade", diante de seus abusos, bem como a posterior publicização do direito civil, terminando por fim no chamado "direito civil-constitucional". em âmbito internacional, estuda-se a autonomia da vontade sob o seu significado neste ramo do direito, qual seja, a possibilidade de escolha da lei aplicável ao contrato internacional.

No capítulo terceiro o exame se detém no instituto da arbitragem, tratando brevemente da Lei 9.307/1996 (LArb), a Lei de Arbitragem brasileira, e suas características e inovações principais acerca da prática arbitral pátria. Nos capítulos quatro e cinco faz-se uma análise do papel da autonomia neste instituto, tanto no plano interno, quanto internacional. Observa-se como o paradigma contratual consagrado no Código Civil de 2002, antes de ser um freio à vontade das partes, constitui-se uma importante ferramenta na proteção do instituto, proibindo manifestações ilícitas da autonomia das partes, como o chamado venire contra factum proprium. Já no plano internacional, faz-se referência à verdadeira revolução instaurada pela LArb, uma vez que supera a discussão acerca da norma de conexão trazida pelo polêmico art. $9^{\circ}$ da Lei de Introdução às Normas do Direito Brasileiro (LINDB), bem como a extensão da plena autonomia da vontade às arbitragens internas, possibilitando a escolha de lei estrangeira à contratos sem elementos de estraneidade. 


\section{A autonomia no Direito Privado interno}

\subsection{Direito Civil}

No campo do Direito Civil, a autonomia privada ${ }^{18}$ consiste no "poder de criação de normas jurídicas particulares, para regramento das relações jurídicas das partes de um dado negócio jurídico contratual"19. Tal autonomia é exercida através da liberdade de estabelecer contratos conferida às partes pelo ordenamento jurídico ${ }^{20}$ Sendo certo que o papel da vontade humana é fulcral em sede de negócio jurídico, gênero do qual o contrato é espécie, uma vez que dela é extraído o seu fundamento ético, desde que atuante em conformidade com a ordem jurídica. ${ }^{21}$

Segundo a lição do grande civilista Caio Mário, tal liberdade é exercida e concretizada nos "quatro momentos fundamentais da existência dos ajustes", a saber: a) a liberdade de contratar e não contratar, i.e., a faculdade de contrair ou não o negócio jurídico bilateral, segundo o foro íntimo do contraente; b) a liberdade da escolha de com quem contratar, não somente o contraente age de acordo com sua vontade para contratar ou não, mas ele também define a pessoa com quem irá constituir a avença; c) liberdade de fixar o que contratar, sendo este o ponto mais sensível para o presente trabalho, uma vez que consiste na liberdade escolher o conteúdo do contrato, de acordo com o sabor da livre conveniência dos contratantes; e d) liberdade de mobilizar o Estado para proteger o que contratar, uma

\footnotetext{
${ }^{18}$ Para o presente trabalho, por questões de semiologia, adotaremos o termo autonomia privada, em consonância com a lição de Teresa Negreiros, deixando o termo "autonomia da vontade" quando da análise do período liberal no séc. XIX e no estudo do direito internacional privado. (NEGREIROS, Teresa. "Teoria do contrato: novos paradigmas", Rio de Janeiro: Renovar, 2006, $2^{\mathrm{a}}$ ed., p.2)

${ }^{19}$ ALMEIDA, Ricardo Ramalho, "Arbitragem Comercial Internacional e Ordem Pública", Rio de Janeiro: Renovar, 2005, p.11

${ }^{20}$ Ainda que silente no Código Civil de 1916, a liberdade de contratar é expressamente prevista pelo hodierno diploma civil pátrio em seu artigo 421: "a liberdade de contratar será exercida em razão e nos limites da função social do contrato". Sobre a aparente omissão do Código de 1916 acerca da liberdade de contratar, e o regramento do diploma civil atual, trataremos posteriormente neste trabalho.

${ }^{21}$ PEREIRA, Caio Mário da Silva. "Instituições de Direito Civil", volume III. Rio de Janeiro: Forense, $12^{\mathrm{a}}$ ed., 2007, p7.
} 
vez que concluído o contrato, passa a ser fonte formal de direito, o que autoriza às partes a faculdade de ingressar ou não em um litígio para ver cumprido aquilo que foi contratado entre elas. ${ }^{22}$ Todavia, salienta o doutrinador, embora haja um campo de liberdade para os contraentes, sobre cada uma destas facetas da liberdade de contratar há atualmente restrições normativas, de modo que não impera um despotismo da vontade, mesmo sendo o contrato, em certo sentido, "expressão da liberdade" 23 .

Tais restrições normativas à autonomia privada podem ser sintetizadas no chamado dirigismo contratual hodierno. Contudo, antes de analisarmos a realidade contratual atual, mister saber o caminho percorrido pela autonomia privada até os dias de hoje, lançando olhos sobre a vontade no direito romano, sua evolução até a chamada "autonomia da vontade" no séc. XIX, passando pela crise deste modelo ocasionando a publicização do direito privado, até assumir os contornos atuais.

\subsubsection{Direito romano}

O condão de ser fonte jurígena dos negócios bilaterais por parte da autonomia da vontade deve-se, em grande parte, pela produção jurídica posterior à Revolução Francesa de 1789. Contudo, embora o papel da vontade tenha alçado níveis muito maiores no séc. XIX, encontrando ali o seu apogeu, esta sempre esteve presente no Direito. Conforme nos ensina Carlos Roberto Gonçalves, a liberdade de contratar é percebida desde o direito romano:

\footnotetext{
"tradicionalmente, desde o direito romano, as pessoas são livres para contratar. Essa liberdade abrange o direito de contratar se quiserem, com quem quiserem e sobre o que quiserem, ou seja, o direito de contratar e de não contratar, de escolher a pessoa com quem fazê-lo e de estabelecer o conteúdo do contrato."24
}

\footnotetext{
${ }^{22}$ Ibidem, pp.22-25.

23 "il contratto è anche espressione di libertà." (ROPPO, Vicenzo, apud. ALMEIDA, Ricardo Ramalho, Op. Cit., p.11).

${ }^{24}$ GONÇALVES, Carlos Roberto. "Direito Civil Brasileiro". São Paulo: Saravia, $6{ }^{\mathrm{a}}$ ed., 2009, p20.
} 
Todavia, o papel da vontade no direito romano, ou "direitos romanos" como prefere José Cretella Júnior, foi sendo alterado ao sabor do tempo. Num primeiro momento, o papel da vontade foi diminuto se comparado com o peso das formas. No dizer do jurisconsulto Paulo nas Sentenças, "ex nudo pacto non nascitur actio" ("de simples pacto não nasce ação" $)^{25}$. Sinal disso é o fato de haver apenas quatro contratos ditos de fato consensuais no sistema romano: venda, locação, mandato e sociedade. Contudo, este princípio da prevalência das formas, aplicado com rígida absolutez num primeiro momento, foi sendo abrandado, dando progressivamente lugar a um aumento do papel do conteúdo e vontade, i.e., intenção, das partes contratantes.

Com efeito, já no Corpus Iuris Civilis de Justiniano $^{26}$ (séc. VI) há a consagração da definição de obrigação como fruto da declaração de vontade, gozando de preponderância sobre o formalismo exterior, marca indelével do negócio jurídico sob a ótica romana. ${ }^{27}$ Gize-se, que vem do Digesto de Justiniano (D. 50.17.23) ${ }^{28}$ a inspiração para o tão comentado art. 1.134 do Código de Napoleão, assunto que abordaremos posteriormente ${ }^{29}$.

\subsubsection{Século XIX e a "autonomia da vontade"}

"Se a economia do mundo do século XIX foi formada principalmente sob a influência da revolução industrial britânica, sua política e ideologia foram formados fundamentalmente pela Revolução Francesa. (...) A França forneceu o vocabulário e os temas da política liberal e radical-democrática

\footnotetext{
${ }^{25}$ CRETELLA JÚNIOR, José. "Curso de direito romano: o direito romano e o direito civil brasileiro no Novo Código Civil”. Rio de Janeiro: Forense, 30a ed., 2007, p174.

${ }^{26}$ Para a história, forma de compilação e temas do Corpus organizado por Justiniano, cf. Ibidem, pp.51-53.

${ }^{27}$ É neste sentido a lição de Caio Mário: "sem poder dizer-se que o romano em tempo nenhum se desvencilhou da sacramentalidade exterior dos atos, é corrente em todos os romanistas esclarecer que chegou a declaração de vontade a projetar-se como element gerador de direitos e obrigações, preponderando sobre a forma exterior" (PEREIRA, Caio Mário da Silva, Op. Cit., p11).

${ }^{28}$ SILVA, Denis Franco, "O princípio da autonomia: da invenção à reconstrução.” In: MORAES, Maria Celina Bodin (Org.). Princípios do direito civil contemporâneo. Rio de Janeiro: Renovar, 2006, p.137.

${ }^{29}$ V. comentários na nota 42 sobre a lição de James Gordley no assunto seguinte.
} 
para a maior parte do mundo. ${ }^{30}$ É com esta declaração que o historiador Eric Hobsbawm inicia seu exame sobre a Revolução de 1789, momento este que iria transformar para sempre a sociedade ocidental em todas as suas esferas, principalmente a jurídica.

Com efeito, dos diversos efeitos trazidos pelas tremulentes bandeiras tricolores de 1789, a consagração do conceito de liberdade política negativa é o que mais nos interessa neste presente trabalho. Tal política liberal está intimamente ligada à ideia de autonomia da vontade humana como fonte jurígena no direito privado. De forma sintética, pode-se resumir esta liberdade na ideia de que livre é o indivíduo quando não impedido por outros, ou pelo Estado, de auto-regrar seus interesses. É a liberdade por não-intervenção ${ }^{31}$. A causa deste pensamento se dá ao analisarmos o ethos jurídico pós-1789, em que a ruptura com a estrutura anterior, já em crise, se deu fruto à reação burguesa diante das fortes limitações impostas pelo Estado durante toda a Idade Média, conforme salientam Eric Hobsbawm ${ }^{32} \mathrm{e}$ Arnoldo Wald ${ }^{33}$. Além dessa filosofia reinante, o indivíduo do séc. XIX é considerado como homo economicus, por conta da Revolução Industrial do final do séc. XVIII, alguém "egoísta e maximizador do próprio interesse", conforme lição de Denis Franco Silva ${ }^{34}$. É neste momento também, fruto desta ideia de liberdade negativa, que a comunidade jurídica, ao contrário da realidade romana ${ }^{35}$, declara a separação das esferas pública e privada, com seus conteúdos totalmente delimitados, funcionando quase impermeavelmente. ${ }^{36}$

\footnotetext{
${ }^{30}$ HOBSBAWM, Eric, “A era das revoluções: 1789 - 1848”, São Paulo: Paz e Terra, $25^{\mathrm{a}}$ ed., 2010, p.97-98.

${ }^{31}$ SILVA, Denis Franco, Op. Cit., p139.

${ }^{32}$ HOBSBAWM, Eric, Op. Cit., p.98.

${ }^{33}$ WALD, Arnoldo, “Obrigações e Contratos". São Paulo: Saraiva, 16 ${ }^{\mathrm{a}}$ ed., 2004, p189.

${ }^{34}$ SILVA, Denis Franco, Op. Cit., p140.

${ }^{35}$ Maria Celina Bodin de Moraes, apoiando-se em René Savatier, explica que na realidade romana o jus civile dos cidadãos romanos era essencialmente uma noção de direito publico. (MORAES, Maria Celina Bodin de, "A caminho de um direito civil-constitucional", In: Na medida da pessoa humana, Rio de Janeiro: Renovar, 2010, p.4).

36 "As relações do direito publico com o direito privado, neste universo jurídico, apresentam-se bem definidas. $\mathrm{O}$ direito privado insere-se no âmbito dos direitos naturais e inatos dos indivíduos.
} 
Destarte, instaurou-se no séc. XIX, o liberalismo individualista como pensamento dominante, trazendo consigo a falsa ideia de igualdade formal, em que todos os indivíduos estão em pé de igualdade e são formalmente iguais perante os outros indivíduos e o Estado ${ }^{37}$. Ademais, o séc. XIX não fora somente conhecido pelo apogeu do liberalismo individualista ${ }^{38}$, mas também como o tempo das grandes codificações, tais como o Bürgerliches Gesetzbuch (Código Civil Alemão) e o Código de Napoleão, sendo este anterior ao BGB e de enorme valia para o estudo do Direito Civil. Tais codificações, principalmente a francesa, embora erguidas sobre estruturas e textos não-liberais, estavam imbuídos do ideário liberal em sua interpretação ${ }^{39}$. Destarte, os princípios liberais burgueses foram lidos, nas palavras de Denis Franco Silva, "para dentro do Código por tratadistas franceses do séc. XIX ${ }^{, 40}$. Caso mais digno de nota é o art. 1.134 do Código de Napoleão ${ }^{41}$, para muitos o grande baluarte da autonomia da vontade, foi, na verdade, como nos instrui James Gordley, parafraseado de uma passagem de Domat, que por sua vez o tomou de decretos promulgados

O direito publico é aquele emanado pelo Estado para a tutela dos interesses gerais. As duas esferas funcionam quase impermeáveis, atribuindo-se ao Estado o poder de impor limites aos direitos dos indivíduos somente em razão de exigências dos próprios indivíduos.” (Ibidem, p.5).

${ }^{37}$ Tal pensamento gerou a ideia de que as partes estão no mesmo pé de igualdade para discutir e negociar qualquer contrato livremente, cf. GONÇALVES, Carlos Roberto, Op. Cit., p.4. Contudo, tal ideia mostrou-se, na realidade, um mito, conforme Max Weber demonstra a falta de ligação necessária entre liberdade formal e material. Cf. notas 28 e 30.

${ }^{38}$ À título de ilustração, conforme nos conta Teresa Negreiros, houve neste tempo certa lei britânica que trazia em seu conteúdo a obrigatoriedade de conexão das casas à rede de esgoto, mediante o pagamento de tributo. A reação por parte do povo foi tamanha que a edição de treze de junho de 1850 do periódico The Economist fez duras críticas contra o "movimento sanitário", aduzindo que os altos índices de mortalidade seriam agravados pela lei, uma vez que a tributação aumentaria a pobreza das massas, e que tal prática pelo Estado acarretaria numa "imbecilidade" da população, por serem tratados como servos ou crianças. Segundo a matéria, "há um mal pior que o tifo ou a cólera ou a água contaminada que é a imbecilidade mental".

${ }^{39}$ Como nos ensina James Gordley: "We have already seen that, in building ther theories, the nineteenth-century jurists almost invariably had to read new meaning into a traditional formulation preserved by the Code." Em tradução livre: "Já vimos que, na construção de suas teorias, os juristas do século dezenove quase invariavelmente tinham de ler novo significado em formulações tradicionais preservadas pelo Código". (GORDLEY, James. "The philosofical origins of Modern Contract Doctrine”, Oxford: Clarendon Press, 1992, p217).

${ }^{40}$ Ibidem, p136.

41 "Les conventions légalement formées tiennent lieu de loi à ceux qui les ont faites. Elles ne peuvent être révoquées que de leur consentement mutuel, ou pour les causes que la loi autorise. Elles doivent être exécutées de bonne foi." ("As convenções legalmente formadas tomam o lugar da lei para aqueles que as tenham feito. Elas não podem ser revogadas, senão por consenso mútuo ou por razões que a lei autorize. Elas devem ser executadas de boa-fé"). 
pelo Papa Bonifácio VIII, que por sua vez o retirou do Corpus Iuris Civilis (no Digesto 50.17.23) de Justiniano, no séc. VI. ${ }^{42}$

Contudo, não obstante suas fontes serem não-liberais, o Código Civil francês de 1804, sendo a primeira grande codificação moderna, disciplinou o contrato como mero instrumento para aquisição da propriedade. Isto porque a propriedade, nas palavras de Maria Celina Bodin de Moraes, é o instituto central do Código Napoleônico, definida naquele diploma, em seu art. 544, como o "direito de gozar e dispor dos bens na maneira mais absoluta". ${ }^{43}$ Nas palavras de Carlos Roberto Gonçalves, o contrato sob esta ótica liberal representava, na realidade, uma garantia para os classes burguesas proprietárias. $^{44}$

Destarte, pela confluência destes fatores, o indivíduo tornara-se praticamente onipotente em sua esfera negocial, podendo livremente decidir contratar, com quem contratar, e o que contratar, conforme lhe fosse conveniente $^{45}$. Nas palavras de Arnoldo Wald, houve uma "mística contratual", onde deixava-se "ao arbítrio de cada um a decisão de todas as

\footnotetext{
${ }^{42}$ Gordley afirma contundentemente que o Código Civil Francês não continha em si uma teoria da vontade. $\mathrm{O}$ argumento do jurista britânico se dá na medida em que praticamente todas as provisões do texto positivo terem sido reproduções de estruturas já estabelecidas, tiradas das obras de Pothier e Domat. Denis Franco Silva, apoiando-se no autor, afirma que o ideário liberal foi lido "para dentro" do código (cf. notas 18 e 19). Assim diz James Gordley: "that the Code did not contain a will theory should be plain from the fact that virtually all its provisions on contracts were lifted, usually verbatim, from the Works of Pothier and Domat. (...) We have already seen that, in building ther theories, the nineteenth-century jurists almost invariably had to read new meaning into a traditional formulation preserved by the Code. Modern scholars in looking for evidence of a will theory in the Code have generally pointed to article 1134, which says that contracts take the place of law between the parties. That statement, however, had been made by Domat (...). Domat had taken it from a collection of decretals of Pope Bonifacius VIII who had taken it in turn from the Digest." Em tradução livre: "Que o Código não contém uma teoria da vontade deveria ser claro pelo fato de que virtualmente todas as suas disposições sobre contratos terem sido trazidas, geralmente verbatim, da obra de Pothier e Domat. (...) Já vimos que, na construção de suas teorias, os juristas do século dezenove quase invariavelmente tinham de ler novo significado em formulações tradicionais preservadas pelo Código. Eruditos modernos na busca pela evidência de uma teoria da vontade no Código geralmente apontam para o art. 1.134, que diz que o contrato tem força de lei entre as partes. Esta declaração, contudo, foi feita por Domat (...). Domat a tirou de uma coleção de decretos do Papa Bonifácio VIII, que por sua vez a tirou do Digesto." (GORDLEY, James, Op. Cit., pp217-218).

${ }^{43}$ MORAES, Maria Celina Bodin de, Op. Cit., p.5.

${ }^{44}$ GONÇALVES, Carlos Roberto, Op. Cit., p.3.

${ }^{45}$ Segundo Carlos Roberto Gonçalves, a Revolução Francesa trouxe uma "predominância do individualismo e a pregação de liberdade em todos os campos, inclusive o contratual" (GONÇALVES, Carlos Roberto, Op. Cit., p.20).
} 
questões econômicas, sem qualquer interferência por parte da sociedade"46. É a autonomia da vontade colocada no centro do Direito Privado, conforme as palavras de Serpa Lopes, para quem "na teoria clássica, todo o edifício do contrato assenta na vontade individual, que é a razão de ser da sua força obrigatória" ${ }^{47}$ Some à autonomia da vontade, o pacta sunt servanda, bem como a relatividade dos efeitos contra terceiros e tem-se erigida a contratualística do modelo clássico.

Contudo, a própria experiência histórica mostrou falho o pressuposto da existência de uma liberdade contratual formal entre os particulares que não gerasse abusos e lesões à esfera jurídica dos indivíduos menos favorecidos. ${ }^{49} \mathrm{Se}$ formalmente o pequeno artesão local pudesse ser igualmente livre comparado ao grande comerciante de joias e artigos de luxo, factualmente a desigualdade entre ambos era gigantesca. Destarte, dizer ser formalmente livre não quer dizer ser materialmente livre. Se a liberdade formal, dada pela ideia de igualdade entre todos os particulares, estando estes num mesmo patamar social, extrai sua fonte do próprio ordenamento jurídico, a liberdade material retira sua razão de ser dos elementos socioeconômicos ${ }^{50}$.

\footnotetext{
${ }^{46}$ WALD, Arnoldo, Op. Cit., p. 190.

${ }^{47}$ LOPES, Miguel Serpa, "Curso de Direito Civil”. Rio de Janeiro: Freitas Bastos, 6a ed., 1996, p33.

${ }^{48}$ Neste mesmo sentido, "a vontade passa a ser o cerne do contrato, e este, o cerne do Direito objetivo como um todo e do próprio Estado.” (NEGREIROS, Teresa, Op. Cit., p.25).

${ }^{49}$ Neste sentido é a lição de Franz Wieacker: "o direito privado abstracto e sua sua autonomia privada - que permitiu pela primeira vez o "livre" ajuste dos salários e das rendas, a responsabilização ilimitada do devedor e do solo, a livre divisão das heranças e a pulverização da propriedade - representou um elemento favorável para os grupos econômicos em expansão da finança, do comércio e da indústria, em desfavor das profissões e classes sem capital em relação às quais a instituição do trabalho assalariado na ordem jurídica do século XIX sublinhou a recusa de uma profissão livre com a instituição de péssimas condições de partida." (WIEACKER, Franz, "História do Direito Privado Moderno", trad. Por A. M. Botelho Hespanha. Lisboa: Fundação Calouste Gulbenkian, 2004, $3^{\text {a }}$ ed., p504.)

${ }^{50}$ Neste mesmo diapasão, afirma Teresa Negreiros que o modelo clássico traz uma lógica coerente, se considerada em si mesma: a lógica do indivíduo em oposição ao trabalhador, consumidor, contribuinte, etc. O indivíduo é definido por "sua irredutibilidade essencial. O 'ser' é a sua única e suficiente qualidade". Contudo, a própria autora contrapõe este pensamento com a concepção hodierna que abandona a igualdade formal do paradigma liberal do séc. XIX em busca de uma igualdade material: "É hoje plenamente aceito, no entanto, que a realidade das relações interprivadas não mais se concilia com perspectivas segundo as quais o direito civil, que as regula, teria como objeto discriminante a disciplina de um indivíduo assim abstrato, partícipe de relações
} 
Max Weber foi um dos que salientou não haver vínculo necessário entre as duas liberdades ${ }^{51}$ (i.e., formal e material):

“(...) o desenvolvimento das relações jurídicas ordenadas em direção à sociedade de contratos, e do próprio direito em direção à liberdade do contrato, especialmente rumo a uma autonomia autorizadora regulamentada por esquemas jurídicos, costuma ser caracterizado como diminuição dos compromissos e aumento da liberdade individual."

Após salientar o aumento da liberdade individual conferida pelo Direito, Weber declara que não há como concluir que uma coisa necessariamente está ligada à outra:

\begin{abstract}
“Em que extensão, como resultado prático, realizou-se também um aumento da liberdade individual na determinação das condições da própria condução da vida, ou em que extensão, apesar disso e talvez, em parte, em conexão com isso, iniciou-se um aumento da esquematização forçosa da vida, não pode ser deduzido unicamente do desenvolvimento das formas jurídicas." (grifou-se). ${ }^{52}$
\end{abstract}

Por conseguinte, no paradigma liberal clássico, os diplomas civis, sendo a "autobiografia" do indivíduo burguês 53 , gozavam de um "status" constitucional, uma vez que a própria concepção de Estado retira seu fundamento do indivíduo, sendo a propriedade privada o seu grande símbolo, constituindo um verdadeiro emblema de liberdade. Com efeito, tal direito gozava de tamanha importância que, juntamente com a liberdade de contratar, "formavam o centro de gravidade do sistema privado", conforme lição de Carlos Roberto Barroso ${ }^{54}$. Tem-se, dessa maneira, a razão por que

jurídicas axiomaticamente fundadas sobre uma igualdade meramente formal. Especialmente no campo do direito contratual, a coerência interna da lógica individualista é incapaz de resistir ao confronto com a realidade e com os problemas postos pelas tão manifestas quanto profundas desigualdades sociais." (NEGREIROS, Teresa, op. cit., p.5).

${ }^{51}$ Ricardo Ramalho Almeida comenta que embora esta distinção seja evidente para a comunidade jurídica hodierna, assim não o era ao longo de todo o séc. XIX e início de séc. XX. O autor cita um famoso emblema contratual que bem espelha o pensamento liberal até então vigente: "quem diz contratual diz justo" de autoria do filósofo francês Alfred Fouillé, em obra datada de 1880. (ALMEIDA, Ricardo Ramalho, Op. Cit., p.15).

${ }^{52}$ WEBER, Max, "Economia e Sociedade: fundamentos da sociologia compreensiva", volume 2. São Paulo: Editora UnB/Imprensa Oficial, $4^{\mathrm{a}}$ ed., 2004, pp65-67.

${ }^{53}$ Em felicíssima locução de Teresa Negreiros (cf. NEGREIROS, Teresa, Op. Cit., p14).

${ }^{54}$ BARROSO, Carlos Roberto, "Curso de direito constitucional contemporâneo: os princípios fundamentais e a construção do novo modelo”. São Paulo: Saraiva, 2009, p.58. 
neste tempo afirmava-se ser o Code a "Constituição do direito privado". 55

Neste sentido afirma Michele Giorgianni:

\begin{abstract}
“esse significado 'constitucional' dos códigos civis do início do século XIX (...) é imanente neles, se se fixar a ideia de que a propriedade privada e o contrato, que constituíam, como se disse, as colunas do sistema, vinham, por assim dizer, 'constitucionalizar' uma determinada concepção da vida econômica, ligada, notoriamente, à ideia liberal."
\end{abstract}

\title{
1.1.4 A mudança de paradigma e a publicização do Direito Civil
}

Se o séc. XIX pode ser chamado como a "época das certezas", em consonância com a locução de Natalino $\operatorname{Irti}^{57}$, coube à época iniciada no século seguinte, indo até os dias de hoje, a alcunha de era das incertezas. ${ }^{58}$ A incerteza se dá, segundo Maria Celina Bodin de Moraes, apoiando-se no jusfilósofo Erhard Denninger, pelo fím da "razão prática universal" kantiana, fonte esta do direito privado que se propunha ser permanente, ideal e racional. ${ }^{59}$ A experiência de horror sofrida com as duas Grandes Guerras, a ideologia nazista e a constatação que a ampla liberdade de contratar gerava, na verdade, desequilíbrios e exploração da parte economicamente mais fraca, ${ }^{60}$ geraram ao longo de todo o séc. XX profundas alterações na sistemática civilista, alterações estas que

\footnotetext{
${ }^{55}$ BARROSO, Carlos Roberto, op. cit., p.59.

${ }^{56}$ GIORGIANNI, Michele, apud NEGREIROS, Teresa, op. cit., p15.

${ }^{57}$ IRTI, Natalino, apud MORAES, Maria Celina Bodin de, "Constituição e direito civil: tendências", In: Na medida da pessoa humana, Rio de Janeiro: Renovar, 2010, p.34.

${ }_{58}^{58}$ Ibidem, p45.

${ }^{59}$ Segundo a eminente civilista, são diversas as circunstâncias que levaram à disseminação destas incertezas, características da pós-modernidade. Contata-se a total impossibilidade de dominar o avanço tecnológico em suas mais amplas dimensões, e.g., a energia nuclear ou a manipulação genética. Por conseguinte, a gigantesca disponibilidade de informação traz consigo um aumento de proporções iguais no leque de desconhecimento, gerando mais incertezas. Aponta a civilista também que o acúmulo de conhecimentos sobre o mundo não trouxe consigo um ganho de sabedoria da pessoa em relação a si própria e o mundo que o cerca, dificultando a convivência coletiva. Por fim, ressalta que o esfacelamento das instituições que auxiliam na construção de identidades coletivas, tais como a Universidade, o Estado Nacional, classes sociais, crenças religiosas, partidos políticos, dentre outros (cf. Ibidem, pp35-38).

${ }^{60}$ Nas palavras de Carlos Roberto Gonçalves, "compreendeu-se que, se a ordem jurídica prometia a igualdade política, não estava assegurando a igualdade econômica. Em alguns setores fazia-se mister a intervenção do Estado, para restabelecer e assegurar a igualdade entre contratantes." (GONÇALVES, Carlos Roberto, Op. Cit. p.23.) Gize-se que o eminente civilista se utiliza da expressão "restabelecer e assegurar a igualdade entre contratantes" em sua lição. Contudo, permitimo-nos questionar se em algum momento houve, no paradigma anterior, igualdade entre os contratantes que não passasse de uma ficção jurídica, eminentemente formal.
} 
resultariam, posteriormente, na migração de paradigma: da individualidade para a solidariedade. ${ }^{61}$ É neste momento que surge o Estado Social, em que as normas constitucionais intervém na ordem econômica e social ${ }^{62}$. A primeira destas mudanças foi a chamada "publicização" 64 do direito privado, marcada, inicialmente, pelo surgimento de normas cogentes, i.e., indisponíveis aos contratantes, o que por si só já representou um enorme avanço se considerarmos o pensamento jurídico individualista que imperava no paradigma liberal clássico. Tem-se, nestas normas, uma importante limitação à autonomia da vontade e seu absolutismo.

A tais normas cogentes convencionou-se chamar de ordem pública ${ }^{65}$, normas limitadoras da liberdade individual e do primado da vontade. ${ }^{66}$ Segundo a lição do ilustre professor Caio Mário, tais normas principiológicas de ordem pública são da maior repercussão na vida social, aduzindo serem princípios de direito privado.

"estas não chegam a constituir direito público, por faltar a
participação estatal direta na relação criada, que se estabelece
toda entre particulares. São, pois, princípios de direito privado.
Mas, tendo em vista a natureza especial da tutela jurídica e a

\footnotetext{
${ }^{61}$ Vale trazer, uma vez mais, a lição de Maria Celina Bodin de Moraes: "Por outro lado, considerase que Por outro lado, considera-se que a incerteza tenha acarretado um grande benefício, benefício que, em perspectiva histórica, parece ter nascido no século XX (...) o benefício chama-se solidariedade. Este sentimento, o senso de igual dignidade para todas as pessoas humanas, é novo; não existia no passado. É novo e decorre da conscientização de 'estarmos todos no mesmo barco'; é, pode-se dizer, a semente criadora de uma nova consciência moral, uma nova ética." (MORAES, Maria Celina Bodin de, Op. Cit., p.38).

${ }^{62}$ Um grande exemplo a ser dado sobre esta intervenção constitucional é a criação de novos ramos do Direito, tal como o Direito Previdenciário.

${ }^{63} \mathrm{Na}$ realidade brasileira, a Lei da Usura (Dec. no. 22.626/1933), bem como o Decreto-Lei no. 58/1937 espelham esta realidade.

${ }^{64}$ Explica Caio Mário da Silva Pereira: "a influência absorvente do Estado e a necessidade de se instituírem, com mais segurança e amplitude, fórmulas cada vez mais dirigidas no sentido de realizar a finalidade precípua do direito que se positiva e se afirma no propósito de garantir e proteger o bem-estar do indivíduo in concreto, cogitando da normação social em atenção ao bem do homem, geram a tendência à publicização da norma juridical. Em consequência deste movimento acentua-se a restrição da liberdade individual, tomando corpo a estatização de numerosos serviços e intervindo o Estado em matérias que antes eram relegadas exclusivamente ao arbítrio de cada um." (PEREIRA, Caio Mario da Silva, "Instituições de Direito Civil", volume I. Rio de Janeiro: Forense, 2005, $21^{\text {a }}$ ed., pp. 19-20).

65 "Para temperar a liberdade contratual e responder ao exacerbado individualismo inerente à concepção estritamente voluntarista do contrato, desenvolveu-se e ampliou-se gradualmente a doutrina da ordem pública, postulando a prevalência desta sobre o poder normativo dos particulares." (ALMEIDA, Ricardo Ramalho, op. cit., p16).

${ }^{66}$ BARROSO, Carlos Roberto, op. cit., p58.
} 
finalidade social do interesse em jogo, compõem uma categoria de princípios que regem relações entre particulares, a que o Estado dá maior relevo em razão do interesse público em jogo. São, pois, princípios de direito privado (...) inderrogáveis pela vontade das partes, e cujos efeitos são insuscetíveis de renúncia. ${ }^{67 "}$.

Acerca da ordem pública (seja ela interna ou internacional) e seu impacto na autonomia da vontade, teceremos análise em momento oportuno. Por ora, faz-se necessário o exame do estágio da autonomia no direito civil hodierno, de acordo com a perspectiva chamada de "civilconstitucional".

\subsubsection{O Código Civil de 1916, o direito civil-constitucional e o Código de 2002}

Conforme dito anteriormente, no modelo liberal clássico estava erigida uma barreira separando a esfera do direito público do privado. Se ao Código Civil cabia regular as relações jurídicas referentes ao indivíduo e sua liberdade, à Constituição caberia, por outro lado, ordenar as relações públicas e proteger o indivíduo "frente ao poder de império do Estado". 68 Neste sentido, considerava-se o direito privado como totalmente autônomo, impassível e intocável diante das mudanças políticas ${ }^{69}$, e de valor maior que a disciplina constitucional.

Entre nós, a proclamação da República em 1889 conferiu, num plano filosófico, grande valor ao positivismo de Comte. Tal pensamento sistematizado, aliado ao este espírito clássico das codificações do séc. XIX, estabeleceram as bases para Código Civil brasileiro de 1916, espírito este, como visto anteriormente, que consagra a ampla liberdade contratual. Em

\footnotetext{
${ }^{67}$ PEREIRA, Caio Mário da Silva, op. cit., p.19.

${ }^{68}$ NEGREIROS, Teresa, Op. Cit., p.49.

${ }^{69}$ Neste sentido, é a lição de Ludwig Raiser: "é uma ingenuidade supor que o direito privado possa ser compreendido com base na evolução das suas instituições, como consequência de condições sociais determinadas historicamente e, ao mesmo tempo, esteja oportunamente protegido do campo da política, quase como se houvera um muro que os separasse. (...) O direito privado tem portanto seguramente uma função política, a qual, a cada época constitucional, é novamente redefinida" (RAISER, Ludwig, apud NEGREIROS, Teresa, op. cit., p11, tradução livre da autora citada).
} 
que pese o CC1916 não trazer em seu texto uma referência expressa sobre tal liberdade, este silêncio, na opinião da doutrina contemporânea é "eloquente",70, uma vez que reportar-se a algo que está nas entranhas do organismo é totalmente desnecessário. Ademais, o projeto do CC1916 foi concluído em 1899, impedindo, portanto, que o diploma absorvesse as aspirações trazidas pelo século $\mathrm{XX} .^{71}$

Pode-se observar no tratamento dado ao contrato pelo CC1916 a presença dos três princípios clássicos, decorrentes da autonomia da vontade do séc. XIX. A autonomia privada, traduzida pela faculdade das partes se obrigarem como e com quem quiserem, sujeitando-se apenas aos limites trazidos pelas normas cogentes, ditas de ordem pública. Por conseguinte, a obrigatoriedade dos pactos, fazendo a avença ter força de lei inter partes, tornando intangível o conteúdo contratual, bem como, a relatividade dos efeitos deste contrato, sendo estes restritos apenas às partes contratantes, não vinculando terceiros. ${ }^{72}$

Contudo, com a constitucionalização de matérias que até então eram relegadas exclusivamente ao direito civil, empreendimento levado à cabo pelas constituições contemporâneas solidaristas ${ }^{73}$ que positivam não somente liberdades negativas, mas também direitos fundamentais que necessitam de prestações positivas, este foi perdendo, paulatinamente, o seu caráter de "constituição do direito privado"74. Igualmente, contribui a esta

\footnotetext{
${ }^{70}$ TEPEDINO, Gustavo, et al. "Código civil interpretado conforme a Constituição da República”, Rio de Janeiro: Renovar, vol. II, 2006, p.6.

${ }^{71}$ AZEVEDO, Fábio de Oliveira, "Direito Civil: introdução e teoria geral". Rio de Janeiro: Lumen

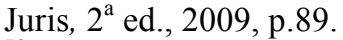

72 Ibidem, p9.

${ }^{73}$ Podemos citar como referência a Constituição de Weimar de 1919, a Constituição de Portugal de 1976, e a espanhola de 1978, assim como o Constituição Federal brasileira de 1988.

${ }^{74}$ Neste sentido, afirma Gustavo Tepedino: "O código civil perde, assim, definitivamente, o seu papel de Constituição do direito privado. Os textos constitucionais, paulatinamente, definem princípios relacionados a temas antes reservados exclusivamente ao Código Civil e ao império da vontade: a função social da propriedade, os limites da atividade econômica, a organização da família, matérias típicas do direito privado, passam a integrar uma nova ordem pública constitucional" (TEPEDINO, Gustavo, "Premissas metodológicas para a constitucionalização do Direito Civil”, In: “Temas de Direito Civil”, Rio de Janeiro: Renovar, $3^{\mathrm{a}}$ ed., 2004, p7).
} 
perda de posição do direito privado o caráter rígido ${ }^{75}$ que a maioria das constituições do sistema continental adotou (tal como a Constituição de 1988), eliminando a crítica clássica feita à norma constitucional de ser volátil, ao passo que a norma de direito privado seria mais estável. Ademais, assumindo uma visão de unidade do ordenamento jurídico, à norma constitucional cabe a posição no topo da pirâmide normativa kelseniana, conferindo legitimidade e validação à todas as outras normas inferiores à ela, inclusas aí, as normas de direito civil.

Ora, na esteira da prática legislativa do pós-positivismo, ${ }^{76} \mathrm{a}$ Constituição da República de 1988 alça a cláusula geral da dignidade da pessoa humana à posição de fundamento da República ${ }^{77}$, consagrando igualmente os valores da solidariedade $\operatorname{social}^{78}$ e isonomia substancial ${ }^{79}$, na esteira das constituições contemporâneas ${ }^{80}$. Destarte, a Constituição da República passa a ser o centro do sistema jurídico, servindo como uma

\footnotetext{
${ }^{75} \mathrm{Na}$ clássica lição de José Afonso da Silva, "rígida é a constituição somente alterável mediante processos, solenidades e exigências formais especiais, diferentes e mais difíceis que a formação das leis ordinárias ou complementares" (SILVA, José Afonso da, "Curso de Direito Constitucional Positivo", São Paulo: Malheiros, 26 ed., 2006, p42.) O constitucionalista faz um contraponto entre a atual CRFB de 1988, de caráter rígido, com a Constituição do Império, datada de 1834, que dispõe em seu art. 178: "É só constitucional o que diz respeito aos limites e atribuições respectivos dos poderes políticos, e aos direitos políticos e individuais dos cidadãos; tudo o que não é constitucional pode ser alterado, sem as formalidades referidas, pelas legislaturas ordinárias."

${ }^{76}$ Segundo Luís Roberto Barroso, o pós-positivismo é o marco filosófico do novo direito constitucional. Segundo o constitucionalista, sua caracterização "situa-se na confluência das duas grandes correntes de pensamento que oferecem paradigmas opostos para o Direito: o jusnaturalismo e o positivismo. Opostos, mas por vezes, singularmente complementares." (BARROSO, Luís Roberto, Op. Cit., pp248-249). Em linhas gerais, o pós-positivismo se resume a uma "terceira via" (nas palavras de Barroso), que busca ir além da legalidade estrita, mas não apresenta desprezo pelo direito positivo, lançando mão de interpretações axiológicas, a normatividade dos princípios, bem como uma teoria de direitos fundamentais edificada sobre a pessoa humana, todos previstos no próprio texto constitucional.

${ }^{77}$ CRFB, Art. 1". "A República Federativa do Brasil, formada pela união indissolúvel dos Estados e Municípios e do Distrito Federal, constitui-se em Estado Democrático de Direito e tem como fundamentos: (...) III - a dignidade da pessoa humana."

${ }^{78}$ CRFB, Art. $3^{\text {o }}$."Constituem objetivos fundamentais da República Federativa do Brasil: I construir uma sociedade livre, justa e solidária".

${ }^{79}$ CRFB, Art. $3^{\circ}$. "Constituem objetivos fundamentais da República Federativa do Brasil: III erradicar a pobreza e a marginalização e reduzir as desigualdades sociais e regionais"

80 “As constituições contemporâneas, em lugar do sujeito abstrato, levam em conta as necessidades concretas, de uma pessoa concreta, situada socialmente, isto é, na sua relação com os seus 'diferentes semelhantes"' (NEGREIROS, Teresa, Op. Cit. p.54.)
} 
espécie de filtro axiológico pelo qual se deve ler o direito civil. ${ }^{81}$ Mostra-se, diante disso, a clara disparidade entre o diploma civil de 1916, patrimonialista em sua essência, e a normativa constitucional, solidarista e personalista da Constituição da República de 1988. Soma-se a esta realidade dispare a promulgação, em 1990, dois anos apenas, portanto, após a Constituição da República, do Código de Defesa do Consumidor (Lei 8.078/1990), texto este que "exprime na disciplina legal dos contratos a nova tábua de valores" $" 82$ trazidos pela CRFB.

Pretendeu-se eliminar a referida disparidade com a promulgação no ano de 2002 da Lei 10.406, um novo Código Civil. Em que pese a opinião de eminentes civilistas ${ }^{83}$ no sentido de o atual Código falhar nesta empreitada, impõe reconhecer que o CC2002 dispõe sobre direitos da personalidade, os novos princípios contratuais, bem como uma cláusula geral de responsabilidade objetiva. Ademais, por lançar mão de cláusulas gerais, permite o legislador que o CC2002 esteja suscetível à novas e fecundas interpretações, sem, contudo, importar em alteração no texto legal. $^{84}$

Especificamente no âmbito dos contratos, os referidos axiomas constitucionais de eticidade e socialidade, trazem à órbita contratual novos

\footnotetext{
${ }^{81}$ BARROSO, Carlos Roberto, Op. Cit., p368. Ver também, do mesmo autor, "Comissões Parlamentares de inquérito e suas competências: Política, direito e devido processo legal." In: "Temas de Direito Constitucional". Rio de Janeiro: Renovar, tomo 1, 2001, p106.

${ }^{82}$ TEPEDINO, Gustavo et al.. Op. Cit., p7.

${ }^{83}$ Para Maria Celina Bodin de Moraes, não obstante alguns avanços do atual Código, "as suas conquistas estão aquém dos entendimentos já manifestados pela jurisprudência e são obscurecidas, pela inclusão de novidades desastrosas, pela permanência, no geral, da lógica tradicional, pela manutenção de dispositivos obsoletos e, ainda, pela consagração de alguns retrocessos." (MORAES, Maria Celina Bodin de, Op. Cit., p50). Neste mesmo sentido é a posição de Gustavo Tepedino, para quem o novo diploma civil já nascia velho: "O novo Código nascerá velho principalmente por não levar em conta a história constitucional brasileira e a corajosa experiência jurisprudencial, que protegem a personalidade humana mais do que a propriedade, o ser mais que o ter, os valores existenciais mais que do que os patrimoniais. E é demagógico porque, engenheiro de obras feitas, pretende consagrar direitos que, na verdade, estão tutelados em nossa cultura jurídica pelo menos desde o pacto político de outubro de 1988." (TEPEDINO, Gustavo, "O novo código civil: duro golpe na recente experiência constitucional brasileira". In: "Temas de direito civil", tomo II, Rio de Janeiro: Renovar, 2004, p.358).

${ }^{84}$ SILVA, Eduardo Silva da. "Código Civil e Arbitragem: entre a liberdade e a responsabilidade". In: Revista Brasileira de Arbitragem, WALD, Arnoldo (Coord.), volume 5, 2005, p53.
} 
princípios, que se não excluem ou anulam os princípios clássicos, com eles interagem, atribuindo novos contornos qualitativos decisivos à disciplina contratual, ${ }^{8586}$ principalmente por sua natureza normativa e aplicação direta nas relações jurídicas sobre as quais vigoram ${ }^{87}$, superando a noção clássica do silogismo positivista da subsunção, em que tem-se a lei (premissa maior), o fato (premissa menor) e a solução legal como conclusão. São eles: a boa-fé objetiva, a função social do contrato e o equilíbrio econômico entre as prestações. $^{88}$

\footnotetext{
85 "Passa-se a reconhecer, nas transformações ocorridas não apenas exceções à dogmática clássica, mas a expressão de novos princípios fundamentais da teoria contratual, capazes de alterar qualitativamente a dogmática e os princípios tradicionais." (TEPEDINO, Gustavo et al., Op. Cit., p9).

${ }^{86}$ Sobre a mudança ocasionada pelos axiomas da Constituição da República de 1988 no direito civil trazido pelo CC1916: "O abandono da perspectiva individualista, nos termos em que era garantida pelo Código Civil, e sua substituição pelo princípio da solidariedade social, previsto constitucionalmente, acarretou uma profunda transformação no âmago da própria lógica do direito civil - que se faz notar nas mais recônditas minudências do sistema. Com efeito, o legislador codicista estava voltado para garantir a igualdade de todos perante a lei - igualdade representativa, à época, de significativo avanço social - posição que era, no entanto, incompatível com o reconhecimento de quaisquer aspectos particulares ou específicos, relativos aos destinatários das normas. Por seu turno, o legislador constituinte teve a pretensão, apoiado nos princípios da dignidade humana e da solidariedade social, de querer enfrentar as desigualdades concretas do contexto da sociedade brasileira contemporânea, ao propugnar, como objetivo fundamental da República - art. $3^{\circ}$, III -, a erradicação da pobreza e da marginalização social” BODIN DE MORAES, Maria Celina, "O princípio da solidariedade". In: Os princípios da Constituição de 1988, PEIXINHO, Manuel Messias et al., (org.), Rio de Janeiro: Lumen Juris, 2001, p.185. Contudo, é da opinião do ex-ministro do Supremo Tribunal Federal, Prof. Eros Grau, que não há algo como um "novo paradigma de contrato". Segundo o eminente jurista, deve-se perseguir tão somente a modernização da teoria clássica do contrato. Para Grau, numa interessante visão econômica do direito, o contrato "instrumenta a jurisdicização de uma ou mais relações negociais travadas entre as partes que dele participam e por ele se obrigam." Destarte, deve a teoria clássica ser modernizada, já que encontrou seu esgotamento diante das circunstâncias da sociedade hodierna. Esta modernização importa em perquirir os interesses substanciais envolvidos, não pela formalidade da teoria clássica, mas através da objetivação e personalização do contrato. Conclui Eros Grau: “(...) sustento que não existe e não deve ser perseguido um "novo paradigma de contrato'. O contrato segue e sempre seguirá viabilizando a fluência de relações de mercado". (GRAU, Eros Roberto, "Um novo paradigma dos contratos?" In: Revista Trimestral de Direito Civil. Rio de Janeiro: Padma, volume 5, janeiro/março de 2001, pp.73-82).

${ }^{87}$ Regras e princípios são categorias normativas, e segundo Robert Alexy, princípios são, assim, "normas que ordenam seja algo realizado na maior medida possível, dentro das possibilidades reais, senão também, das jurídicas". Ou seja, se caracterizam pelo fato de que podem ser cumpridos em maior ou menor grau, enquanto que as regas somente podem ser cumpridas ou não." (SILVA, Denis Franco, Op. Cit., p.146).

${ }^{88}$ Neste sentido, trazemos novamente as palavras de Teresa Negreiros, para quem "o processo de constitucionalização do direito civil implica a substituição do seu centro valorativo - em lugar do indivíduo surge a pessoa. E onde dantes reinava, absoluta, a liberdade individual, ganha significado e força jurídica a solidariedade social.” (NEGREIROS, Teresa, Op. Cit., p11).
} 
O primeiro destes, a boa-fé objetiva, retira seu fundamento da própria norma constitucional, ${ }^{89}$ e foi primeiramente consagrado de forma expressa $\mathrm{CDC}^{90}$. Sua previsão no $\mathrm{CC} 2002$ se dá no art. 421, cujo conteúdo é: “a liberdade de contratar será exercida em razão e nos limites da função social do contrato". Segundo Gustavo Tepedino, dentre os novos princípios contratuais, este é o que "atua preponderantemente sobre a autonomia privada" ${ }^{91}$, e assim o é pois migra-se da boa-fé subjetiva para a objetividade do comportamento. Em outras palavras, na boa-fé subjetiva tem-se a intenção do agente investigada para saber se houve ou não inobservância da boa-fé. ${ }^{92}$ Para ilustração, podemos observar o caráter subjetivo, pensamento do antigo paradigma, no Esboço de Teixeira de Freitas, em 1850 (que em muitos aspectos deu o tom do CC1916):

Art. 517. Consiste a boa-fé dos atos jurídicos na intenção de seus agentes relativamente a terceiros, quando procedem sem simulação ou fraude.

Art. 518. Reputar-se-á ter havido boa-fé nos atos jurídicos, ou nas suas disposições, enquanto não se provar que seus agentes procederam de má-fé, isto é, com um dos vícios do artigo antecedente (arts. 504 e 505 , no. 3 ) ${ }^{93}$

\footnotetext{
${ }^{89} \mathrm{O}$ princípio extrai sua base da CRFB/88, a saber: a dignidade da pessoa humana (art. $1^{\circ}$, III); o valor social da livre iniciativa (art. $1^{\circ}$, IV); a solidariedade social (art. $3^{\circ}$, I); bem como da igualdade social (art. $3^{\circ}$, III). Tais dispositivos são conjugados à dicção do art. 170, também da CRFB, que declara a instrumentalidade da atividade econômica para a busca dos objetivos da ordem constitucional.

90 “Art. $4^{\circ}$ A Política Nacional das Relações de Consumo tem por objetivo (...) III - harmonização dos interesses dos participantes das relações de consumo e compatibilização da proteção do consumidor com a necessidade de desenvolvimento econômico e tecnológico, de modo a viabilizar os princípios nos quais se funda a ordem econômica, sempre com base na boa-fé e equilíbrio nas relações entre consumidores e fornecedores"; e "Art. 51. São nulas de pleno direito, entre outras, as cláusulas contratuais relativas ao fornecimento de produtos e serviços que: (...) IV estabeleçam obrigações consideradas iníquas, abusivas, que coloquem o consumidor em desvantagem exagerada, ou sejam incompatíveis com a boa-fé ou a equidade"

${ }^{91}$ TEPEDINO, Gustavo, "Novos princípios contratuais e teoria da confiança: a exegese da cláusula to the best knowledge of the sellers" In: Revista Forense, n. 377, p.242.

${ }^{92}$ Nas palavras de Fábio de Oliveira Azevedo, "é possível agir com boa-fé subjetiva, se a deslealdade ocorreu 'sem querer', ou seja, se ausente a culpa do sujeito ao agir ou omitir-se." (AZEVEDO, Fábio de Oliveira, Op. Cit., p.95).

${ }^{93}$ FREITAS, Teixeira A., "Esboço", Rio de Janeiro: Ministerio da Justiça e Negocios Interiores, 1952 , p. 271
} 
Já a boa-fé objetivada, dever de conduta que é, prescinde do exame de culpa para saber se houve ou não violação ao preceito. Nas palavras da eminente Judith Martins-Costa:

“(...) é um modelo de conduta social, arquétipo ou standard jurídico, segundo o qual cada pessoa deve ajustar a própria conduta a esse arquétipo, obrando como obraria um homem reto: com honestidade, lealdade, probidade. ${ }^{94}$

Consubstancia a boa-fé objetiva numa limitação à autonomia privada porque ainda que não haja má-fé do contratante, este deve se ater ao standard de conduta da boa-fé, em respeito ao outro convenente.

Três são as funções do novo princípio apontadas pela doutrina. ${ }^{95}$ Primeiramente, a boa-fé objetiva serve de regra de interpretação (função esta que encontra ecos no art. 131 do Código Comercial $^{96}$ ) às estipulações contratuais, especificando a finalidade do acordo à luz dos fatos que o cercam. Tem também a boa-fé caráter integrativo na hermenêutica, uma vez que o art. 113 do CC2002 versa sobre seu uso diante de lacuna contratual, sendo ferramenta nas mãos do juiz ou árbitro para fixar deveres secundários de prestação. ${ }^{97}$ É, enfim, a ferramenta hermenêutica que auxilia o julgador na persecução do sentido e alcance das cláusulas contratuais, de modo a impedir que o contrato atinja finalidade oposta àquela que se pretendeu chegar. ${ }^{98}$

Em segundo lugar, a boa-fé objetiva cria deveres ditos laterais ao objeto central da prestação. Segundo esta faceta do princípio, não apenas existe um dever de não prejudicar a outra parte contratante, mas impõe-se

\footnotetext{
${ }^{94}$ MARTINS-COSTA, Judith, A boa-fé no Direito Privado, São Paulo: Revista dos Tribunais, 2000, p. 411.

${ }^{95}$ Neste sentido, MARTINS-COSTA, Judith, Op. Cit., p427; AZEVEDO, Fábio de Oliveira, Op. Cit., pp96-98; PEREIRA, Caio Mário da Silva, Op. Cit., pp20-21.

96 “Art. 131 - Sendo necessário interpretar as cláusulas do contrato, a interpretação, além das regras sobreditas, será regulada sobre as seguintes bases: 1 - a inteligência simples e adequada, que for mais conforme à boa fé, e ao verdadeiro espírito e natureza do contrato, deverá sempre prevalecer à rigorosa e restrita significação das palavras; (...)"

${ }^{97}$ AZEVEDO, Fábio de Oliveira, Op. Cit., p96.

${ }^{98}$ MARTINS-COSTA, Judith, Op. Cit., p432.
} 
deveres de conduta inter partes, independentemente da vontade delas ${ }^{99}$, e ainda que haja omissão no contrato. ${ }^{100}$ A prestação passa de único dever, para o principal deles, coexistindo com aqueles acessórios trazidos pela cláusula contratual do art. 422, mandatória que é. Por conseguinte, se violados quaisquer destes deveres, seja principal, seja acessório, descortinase diante da parte lesada a faculdade de dissolver a relação, diante do inadimplemento por violação positiva do contrato ${ }^{101}$. Vale notar que esta situação pode se fazer presente ainda que as partes não convencionem (i.e., independe da vontade) o respeito à tais deveres laterais ${ }^{102}$, uma vez que o art. 422 é mandatório, o que demonstra uma clara limitação da autonomia privada, situação impensável no modelo clássico do séc. XIX.

Por fim, a terceira faceta da boa-fé objetiva é a de limitadora de direitos subjetivos, proibindo exercícios considerados arbitrários e irregulares, imerecidos de tutela do ordenamento jurídico, o que resultou na construção de doutrinas como a proibição do comportamento contraditório e o abuso de direito.

Ainda dentro desta realidade de novos princípios contratuais, tem-se a função social do contrato, positivada no diploma civil de 2002 no art. 421, fazendo referência expressa também à liberdade de contratar, cujo teor é o seguinte:

\footnotetext{
${ }^{99}$ TEPEDINO, Gustavo et al., Op. Cit., p18.

${ }^{100}$ Neste sentido se posiciou a Terceira Turma do STJ, em voto de relatoria da Min. Nancy Andrighi: "A boa fé objetiva, verdadeira regra de conduta, estabelecida no art. 422 do CC/02, reveste-se da função criadora de deveres laterais ou acessórios, como o de informar e o de cooperar, para que a relação não seja fonte de prejuízo ou decepção para uma das partes, e, por conseguinte, integra o contrato naquilo em que for omisso, em decorrência de um imperativo de eticidade, no sentido de evitar o uso de subterfúgios ou intenções diversas daquelas expressas no instrumento formalizado." (grifamos) STJ, REsp 830526/RJ, Rel. Min. Nancy Andrighi, Brasília, 03 de setembro de 2009.

${ }_{101}$ TEPEDINO, Gustavo et al., Op. Cit. p.18.

${ }^{102}$ Segundo Judith Martins-Costa, os deveres laterais podem ser agrupados em: a) deveres de cuidado, previdência e segurança; b) deveres de aviso e esclarecimento; c) deveres de informação; d) deveres de prestar contas; e) deveres de colaboração e cooperação; f) proteção e cuidado com a pessoa e o patrimônio da contraparte; g) omissão e de segredo. (MARTINS-COSTA, Judith, Op. Cit., p.439).
} 
Art. 421. A liberdade de contratar será exercida em razão e nos limites da função social do contrato.

Embora o legislador pátrio tenha se utilizado da expressão "liberdade de contratar", o sentido aqui é a autonomia privada em geral, e não apenas uma de suas facetas, compreendida pela doutrina como a liberdade de contratar, stricto sensu. ${ }^{103}$ Vale dizer que tal dispositivo altera fortemente a função do contrato segundo o seu sentido moderno, clássico. Se outrora o acordo de vontades tinha apenas uma clara função econômica, sendo expoente do pensamento jurídico-econômico liberal, hoje deve haver nele uma clara função social. Em outras palavras, deve o contrato além de ser economicamente benéfico, socialmente útil. ${ }^{104}$

Em síntese, pode-se afirmar que o paradigma contratual hodierno insere-se no espaço compreendido entre a autonomia e responsabilidade. Nas palavras de Eduardo Silva e Silva:

"Ao mesmo tempo em que o Código reorganiza o atuar dos
sujeitos de direito confirmando-lhes a ampla liberdade de
contratar, já assentada em base constitucional, também disciplina
as obrigações e responsabilidades pelo uso desta liberdade, ainda
que não expressamente desejadas pelas partes, por força dos
ditames da boa-fé objetiva. À liberdade impõe-se a
responsabilidade."

Discute-se na doutrina contemporânea se nos hodiernos contornos da autonomia privada foi a vontade limitada ${ }^{106}$, ou antes, qualificada ${ }^{107}$. Certo é, contudo, como salienta Ricardo Ramalho Almeida, que os contratos ainda nascem, hoje e sempre, da atuação da vontade, não mais absolutizada,

\footnotetext{
103 “a liberdade de contratar a que se refere o art. 421 não se restringe apenas à decisão sobre o ato em si de contratar, mas abrange igualmente a escolha do contratante e, sobretudo, a decisão sobre o conteúdo do regulamento contratual” (TEPEDINO, Gustavo et al, Op. Cit.,p6).

${ }^{104}$ GAMA JUNIOR, Lauro, "Contratos internacionais à luz dos principios do UNIDROIT 2004: Soft Law, Arbitragem e Jurisdição", Rio de Janeiro: Renovar, 2006, p284.

${ }^{105}$ SILVA, Eduardo Silva da. Op. Cit., p53.

${ }^{106}$ Neste sentido, é a posição de WALD, Arnoldo. Op. Cit., pp190-191.

107 "A grande revolução do Direito Contratual não surgiu de novas normas, mas sim de uma nova perspectiva, ao contrário do que concluiu a crítica da doutrina mais tradicional, não diminuiu a esfera da liberdade privada e sim a qualificou." (SOTO, Paulo Neves, "Novos Perfis do direito contratual", in RAMOS, Carmem Lúcia Silveira (org.) et al, Diálogos sobre direito civil, Rio de Janeiro: Renovar, 2002, p.251).
} 
não mais de um sujeito supostamente autônomo, mas de uma pessoa concreta, inserida num contexto socioeconômico:

\begin{abstract}
"É certo, porém, que a autonomia privada, balizada pela supremacia da ordem pública, permanece como fenômeno ordinário do tráfego negocial, pois, no comum dos casos, (1) há declaração ou outra manifestação subjetiva das partes (i.e., o contrato existe), (2) há uma vontade comum, lícita, claramente expressa na declaração ou manifestação negocial, à qual nenhum fato vicioso se pode opor, não sendo, tampouco, ofensiva a leis inderrogáveis e conformando-se às exigências da ordem pública e dos bons costumes (i.e., o contrato é válido), e, (3) a declaração da vontade comum das partes, assim produzida, é apta à produção de seus regulares efeitos (i.e., o contrato é eficaz). Contudo, mesmo estas situações ordinárias serão sempre melhor compreendidas e disciplinadas à luz da boa-fé objetiva, da função social do contrato e da justiça contratual." ${ }^{\text {108 }}$
\end{abstract}

É neste contexto que é promulgada a Lei 9.307/1996, a Lei de Arbitragem (LArb), Lei esta que, na opinião de dois de seus coautores Pedro Batista Martins, "consagrou o princípio da autonomia da vontade", e Selma Lemes, para quem a autonomia da vontade constitui a "própria essência" do instituto da arbitragem. ${ }^{109}$ Contudo, antes de analisarmos o impacto que a LArb trouxe na ordem interna e internacional de nossa República, cabe analisarmos a evolução da vontade no âmbito internacional.

\footnotetext{
${ }^{108}$ ALMEIDA, Ricardo Ramalho, Op. Cit., pp17-18.

${ }^{109}$ LEMES, Selma Ferreira, "Arbitragem. Princípios jurídicos fundamentais. Direito brasileiro e comparado.” In: Revista de informação legislativa, Brasília, ano 29, no. 115, 1992, p463.
} 


\section{A vontade no Direito Internacional Privado}

Se cada Estado possui seu próprio ordenamento jurídico, sendo este aplicado às relações jurídicas dentro de suas próprias fronteiras, o que falar das relações que não se limitem a um único território, ou indivíduos de um único Estado, enfim, relações estas que extrapolem o limite de um único Estado soberano? À medida que o número de relações internacionais cresce entre diversos países, fruto do arranjo globalizado hodierno, o conflito entre sistemas jurídicos diferentes é fato cada vez mais recorrente nas relações jurídicas internacionais. Tal fenômeno é o que Jacob Dolinger classificou como "internacionalização da vida" "110. Para a resolução de tais conflitos de leis no espaço, o Direito Internacional Privado cumpre o seu papel, sendo esta mesma, nas palavras de Nadia de Araujo, sua tarefa precípua. ${ }^{111}$

Já aqui cabe uma importante distinção. A definição do termo autonomia da vontade (privada) possui sentidos diversos dependendo do ramo jurídico a ser estudado. Assim o é porque se no plano interno a autonomia representa a liberdade de escolher o conteúdo do contrato dentro dos limites impostos pela lei, no plano internacional a autonomia da vontade se expressa pela liberdade das partes de escolherem outro sistema jurídico para regular o contrato. ${ }^{112} 113114$

\footnotetext{
${ }^{110}$ DOLINGER, Jacob, Op. Cit., p.1.

111 ARAUJO, Nadia de, "Contratos Internacionais: autonomia da vontade, Mercosul e convenções internacionais." Rio de Janeiro: Renovar, 2009, $4^{\mathrm{a}}$ ed., p.7. Salientamos aqui a resolução de conflitos entre leis, no entanto sabedores que a disciplina jurídica do Direito Internacional Privado tem em seu objeto, somados ao conflito de leis no espaço, igualmente o estudo da nacionalidade, a condição jurídica do estrangeiro, assim como o conflito de jurisdições, conforme a clássica concepção francesa.

${ }_{112}$ ARAUJO, Nadia, Op. Cit., p51.

${ }^{113}$ Também é a lição de Florisbal de Souza, para quem a autonomia da vontade, em sede de direito internacional privado, representa "direito de as partes elegerem a a lei que vai disciplinar o ato". (DEL'OLMO, Florisbal de Souza, "Direito Internacional Privado: abordagens fundamentais, legislação, jurisprudência". Rio de Janeiro: Forense, $4^{\mathrm{a}}$ ed., 2004, p134).

${ }^{114}$ Assim também Claudio Finkelstein: "pela eleição da lei aplicável, as partes indicam exatamente qual a lei que desejam elas seja aquela lei a reger as obrigações contraídas. Essa faculdade atribuída às partes de escolher a lei que sera aplicável ao contrato celebrado deriva do chamado princípio da autonomia da vontade" (FINKELSTEIN, Cláudio, "A Reserva Legal do Direito Internacional Privado Brasileiro" In: MENEZES, Wagner (Org.) O direito internacional e o direito brasileiro: homenagem a José Francisco Rezek, Ijuí: Unijuí, 2004, p855.)
} 
Por conseguinte, se no campo do Direito Civil o olhar para autonomia privada passou por diversas modificações, no plano do Direito Internacional Privado a autonomia da vontade encontra solo fértil para florescer sem grandes restrições como no plano interno dos países.

A autonomia da vontade desempenha grande papel na luta contra incerteza jurídica, decorrente da dúvida gerada pelas mais diferentes regras de conexão. Ademais, é ferramenta eficaz para a busca da harmonização das regras em âmbito internacional, cujo objetivo é o maior grau de relações jurídicas entre particulares de diferentes nações. Sobre a harmonização, ensina Nadia de Araujo:

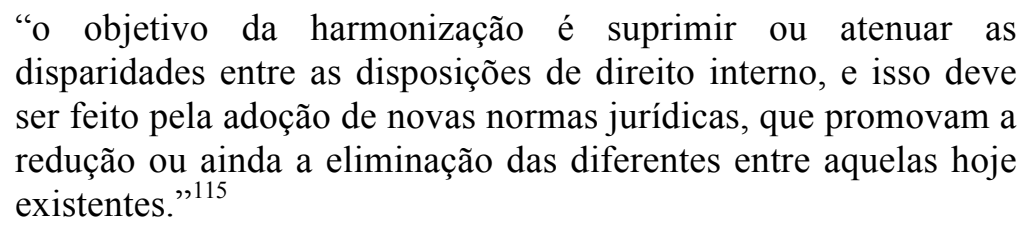

Vale dizer que hodiernamente a autonomia da vontade é reconhecida e aceita universalmente nos contratos internacionais. Nas palavras de Irineu Strenger, a autonomia da vontade é o "princípio objetivado em todo complexo comportamental do comércio internacional". ${ }^{116}$ Mister, para propósitos do nosso estudo, saber a evolução do conceito até os dias presentes.

\subsection{Evolução da doutrina comparada}

O período das grandes codificações do séc. XIX também afetou a disciplina, cujos primórdios remontam ao ius gentium do direito romano ${ }^{117}$. Contudo, em que pese a extensa evolução da disciplina no decorrer dos

\footnotetext{
${ }^{115}$ ARAUJO, Nadia de. Op. Cit. p14.

${ }^{116}$ STRENGER, Irineu, "Direito do comércio internacional e lex mercatoria". São Paulo: LTr, 1996, p.91.

${ }^{117}$ É neste sentido a lição de Dolinger, em que pese não ser o ius gentium um verdadeiro sistema de normas indiretas para solucionar conflitos de leis. No entanto, assinala o doutrinador que estas regras visavam abarcar através de um direito uniforme as relações jurídicas entre estrangeiros, e estes com cidadãos romanos, criando, assim, "efetivamente uma solução para os conflitos de leis, no que se descortinaria um primórdio do Direito Internacional Privado" (DOLINGER, Jacob, Op. Cit., p130).
} 
anos, é de maior interesse para este trabalho salientar a contribuição da escola francesa, bem como as doutrinas modernas sobre a máteria ${ }^{118}$. É de extrema valia a contribuição da escola francesa de DIPr, principalmente na pessoa de Charles Dumoulin, advogado parisiense que viveu entre os anos de 1500 a 1566, cuja grande contribuição foi primeiramente introduzir a teoria da autonomia da vontade no estudo da disciplina ${ }^{119}{ }^{120}$. Entendia Dumoulin que havia uma presunção de que as partes, ao escolherem um determinado local para a assinatura de um contrato, foi porque desejaram se submeter às leis daquele lugar. ${ }^{121}$

A tese de Dumoulin foi primeiro exposada em seu parecer para o casal Ganey, no ano de 1525. A questão resumia-se num conflito de leis entre Paris e outras províncias da França. Vale lembrar que naquele tempo não havia ainda uma codificação nacional, o que ocasionava o tratamento de leis estrangeiras entre as diversas províncias daquele país. No caso do casal Ganey, os nubentes haviam se casado em Paris, sendo que esta província previa o regime de comunhão dos bens, ao passo que no sul da França, local dos bens do casal, vigorava o regime de separação. Diante dessa situação, levantou-se a questão: qual lei deveria ser aplicada? Dumoulin pronunciou-se favoravelmente à aplicação da Lei de Paris, por ser esse o local escolhido pelo casal para o casamento, bem como o domicílio conjugal deles, o que na opinião do jurista francês, indicava uma escolha tacitamente feita por ambos para reger o conjunto de seus bens. A tese de Dumoulin era: a convenção feita pelos cônjuges sobre os bens era um contrato, e sua lei aplicável não devia ser a do local da celebração, mas

\footnotetext{
${ }^{118}$ Para uma história do Direito Privado, cf. DOLINGER, Jacob, Op. Cit., pp127-148.

${ }^{119}$ ARAUJO, Nadia, Op. Cit., p56.

${ }^{120}$ Neste mesmo sentido, AMORIM: "coube a Charles Dumoulin a iniciativa de criar, já no século XVI, a autonomia da vontade como elemento de conexão." (AMORIM, Edgar Carlos de, "Direito Internacional Privado", Rio de Janeiro: Forense, 2005, p34).

${ }^{121}$ No caso do casal Ganey, os nubentes se casaram em Paris, sendo que esta província previa o regime de comunhão de bens, ao passo que no sul, local dos bens do casal, vigorava o regime de separação. Diante dessa situação, levantou-se a questão: qual lei seria aplicada? Domoulin pronunciou-se favoravelmente à aplicação da Lei de Paris, por ser esse o local do casamento e domicílio conjugal do casal, o que, na sua opinião, indicava a escolha tacitamente feita por ambos para reger o conjunto de seus bens. Segundo Domoulin, quando a eleição fosse expressa, devia ser respeitada, e quando tácita, interpretada.
} 
daquele lugar desejado pelas partes, em razão de sua autonomia para a escolha. Se expressa a eleição, respeito. Se tácita, interpretada. ${ }^{122}$

Ainda na escola francesa, em sentido totalmente diverso posicionouse Bernard d'Argentré, magistrado na Bretanha e grande defensor do territorialismo, para quem as leis bretãs deviam ser aplicadas na Bretanha e apenas ali. Em decorrência disso, as leis estrangeiras não deveriam ser aplicadas na Bretanha, de modo que todos os bens situados e pessoas domiciliadas naquele território deveriam ser regidos pelas leis locais, de modo que a aplicação de lei estrangeira é restringida ao máximo. Segundo Dolinger, D'Argentré era um dogmático que punha acima de tudo a sua lei, sendo apenas excepcional que um juiz invoque a lei estrangeira. ${ }^{123}$

Posteriormente, já no séc. XIX, o Código Napoleônico (1804), seguido do Código Civil italiano (1865) e por fim, o BGB alemão de 1896 positivaram regras básicas sobre o conflito de leis no espaço ${ }^{124}$. É neste momento que surgem dois dos grandes nomes da matéria, reverenciados até hoje por sua vanguarda e contribuições ímpar para o estudo do DIPr: Joseph Story e Friedrich Carl von Savigny.

O primeiro deles foi jurista de grande relevo da Universidade de Harvard, cuja célebre obra "Commentaries on the Conflict of Laws, foreign and domestic, in regard to marriages, divorces, wills, sucessions and judgments" ${ }^{225}$ datada de 1834 sobre o conflito de leis no espaço é a

\footnotetext{
${ }^{122}$ Para mais informações sobre o caso Ganey, cf. ARAUJO, Nadia, Op. Cit., pp.56-57, e DOLINGER, Jacob, Op. Cit., pp.137-138.

${ }^{123}$ DOLINGER, Jacob, Op. Cit., p.139.

${ }^{124}$ No entanto, Jacob Dolinger ressalta que o Direito Internacional positivo foi inaugurado com o Código de Frederico o Grande, datado de 1794, tratando do direito geral nos estados prussianos e que trazia consigo algumas regras de conexão. $\mathrm{O}$ autor faz ainda um apanhado da influência dos três códigos citados na codificação dos Estados europeus, como por exemplo a adoção do Código de Napoleão pela Bélgica em 1807. (Ibidem, p142).

${ }^{125}$ Digna de nota é a abertura que Story faz de sua obra, falando sobre a existência do conflito de leis entre os povos: "The Earth has long since been devided into distinct Nations, inhabiting different regions, speaking different languages, engaged in different pursuits, and attached to different forms of government. It is natural, that under such circunstances, there should be many variances in their institutions, customs, laws and polity; and that these variances should result sometimes from accident, and sometimes from design, sometimes from superior skill and knowledge of local interests, and sometimes form a choice founded in ingnorance." Em tradução
} 
primeira a trazer a denominação "Direito Internacional Privado" em seus escritos. Postulou o jurista de Harvard o império da lex loci contractus, ${ }^{126}$ não havendo de se falar em autonomia da vontade para escolha da lei aplicável nos contratos internacionais por uma questão de soberania estatal. ${ }^{127}$ Nas palavras de Jürgen Samtleben, em Story "fica excluída por completo a noção de autonomia da vontade ou da eleição da lei aplicável que só no meio do século reaparece na doutrina europeia”. 128

Por outro lado, Savigny, o virtuose jurídico, conferiu maior contribuição para o estudo da autonomia da vontade no DIPr. Embora não tenha usado o termo autonomia em seu System des heutigen Romischen Rechts para referir-se ao papel da vontade na escolha da lei a ser aplicável, Savigny traz a teoria da jurisdição especial da obrigação, o "lugar" a qual pertence. Para Savigny, tal "lugar" (reichtsgebiet) está identificado com a "sede" (sitz) da relação, sendo certo que tal "lugar" não coincide necessariamente com o lugar da sua celebração, não se aplicando, destarte, a lex loci contractus. ${ }^{129}$ Em outras palavras, sendo a sede da relação contratual o local de sua execução, e uma vez estabelecida a sede da relação, tem-se a determinação do direito local a ser aplicável. ${ }^{130}$ Nas

livre: “A Terra há muito tempo tem sido dividida entre nações distintas, habitando diferentes regiões, falando diferentes línguas, envolvidas em diferentes objetivos, e ligadas à diferentes formas de governo. É natural que, sob tais circunstâncias, deveriam haver diferentes variações em suas próprias instituições, costumes, leis e políticas; e que tais variações deveriam ser resultado ora por acidentes, ora por escolha, ora por capacidade superior e conhecimento dos interesses locais, ou por vezes da escolha baseada na ignorância..." (STORY, Joseph, apud. DOLINGER, Jacob, Op. Cit., p2.)

${ }^{126}$ Em linhas gerais, a lex loci contractus importa na regência da lei do local de celebração do contrato para sua validade, interpretação e resolução.

127 "It would be more correct to say that the law of the place of the contract acts upon it, independently of any volition of the parties, in virtue of the general sovereignty possessed by every nation to regulate all persons, property, and transactions within its own territory" Em tradução livre: "Seria mais correto dizer que a lei do lugar do contrato age sobre ele, independentemente de qualquer vontade das partes, em virtude da soberania em geral possuída por qualquer nação para regular pessoas, propriedade, e transações dentro de seu próprio território." (STORY, Joseh apud SAMTLEBEN, Jürgen, "Teixeira de Freitas e a autonomia das partes no direito internacional privado latino-americano" In: Revista de Informação Legislativa, no. 85, 1985, p259.)

${ }^{128}$ SAMTLEBEN, Jürgen, Op. Cit., p259.

${ }^{129}$ Ibidem, pp260-261.

${ }^{130}$ ARAUJO, Nadia, Op. Cit., p58. Neste mesmo sentido, DOLINGER, Jacob, Op. Cit., p147. 
palavras de Savigny, a verdadeira sede da obrigação coincide com a jurisdição especial da mesma. ${ }^{131}$

Contudo, diante destes conceitos, e para o propósito deste estudo, pergunta-se se às partes há a possibilidade de escolha da lei aplicável, e portanto, o "lugar" da obrigação, segundo a visão do jurista alemão. Para Samtleben, não fica claro a posição adotada por Savigny ${ }^{132}$. Aponta o autor duas posições da doutrina: a primeira, apoiada por diversos autores alemães, advoga que a concepção de Savigny refere-se exclusivamente à escolha do local de execução do contrato. Destarte, a vontade é exercida no sentido de escolher-se livremente o local em que a obrigação será concluída, caso não haja oposição pela natureza do contrato em questão. Contudo, uma vez definido o local de execução, é aquela lei que será obrigatoriamente aplicada, não podendo as partes se afastarem da mesma, com exceção na hipótese da própria lei permitir o afastamento de seu conteúdo. Por outro lado, a segunda entende haver em Savigny uma ampla visão da autonomia, por conta de alguns trechos da sua obra ${ }^{133}$, em que há a faculdade das partes em eleger diretamente (e não indiretamente, como na primeira posição) o direito aplicável, como parte do contrato, independentemente de ser ou não a lei do local de execução. Contudo, tal eleição se dá somente na medida que respeita o que hoje é caracterizado como ordem pública de efeitos internacional.

Voltando aos franceses, durante os séculos XIX e XX outros nomes se levantaram favoráveis e contrários ao princípio da autonomia da vontade. Entre os favoráveis, destaca-se Henri Batiffol, que embora sendo defensor

131 "La juridiction spéciale de l'obligation (ce qui coincide avec la véritable siège de l'obligation)..." Em tradução livre de Nadia de Araujo, "A jurisdição especial da obrigação (que coincide com a verdadeira obrigação)..." SAVIGNY, Friedrich Carl von, apud ARAUJO, Nadia, Op. Cit., nota 12.

${ }^{132}$ SAMTLEBEN, Jürgen, Op. Cit., p261.

${ }^{133}$ Samtleben, traduzindo o autor de sua obra original alemã, registra: "É sempre o lugar da execução que determina o foro especial, seja fixado por declaração expressa ou por aceitação tácita. Em ambos os casos trata-se duma submissão voluntária a este foro, a não ser que seja excluído por declaração expressa em sentido contrário (...) este direito territorial deixa também de ser aplicável, se à presunção da submissão voluntária se opõe uma declaração expressa em sentido contrário" (SAVIGNY, Friedrich Carl Von, apud SAMTLEBEN, Jürgen, Op. Cit., p262). 
da autonomia da vontade, dizia ser possível às partes a faculdade de afastar leis ditas facultativas, restando as imperativas à salvo da vontade das partes. Vale notar que a visão de Batiffol se deu diante da constatação das desigualdades econômicas, ocasionando a opressão do mais forte sobre o mais fraco no plano contratual, havendo assim, a necessidade do legislador limitar a liberdade contratual, eliminando possíveis abusos. Entre os contrários, destacam-se Mailher Chassat, Jean Paulin Niboyet, para quem não haveria de se falar em uma teoria da autonomia da vontade, apenas certa liberdade para estipulação do conteúdo contratual e Alain Pellet, defensor da vontade apenas no que tange a liberdade de contratar, não havendo liberdade contratual para afastar regras imperativas de direito interno, com obrigatoriedade também em âmbito internacional. ${ }^{134}$

Contudo, embora os autores acima referidos tenham tido peso na discussão doutrinaria sobre uma teoria da autonomia da vontade, nos tribunais franceses a jurisprudência caminhou no sentido favorável ao princípio. No leading case American Trading Co. a Corte de Cassação francesa estabeleceu como aplicável a lei escolhida pelas partes ${ }^{135}$. Entendeu a Corte, numa complexa decisão, que a escolha da lei pode se dar tanto pela vontade expressa, quanto por fatos e circunstâncias que a induzam, e ainda, que a lex loci contractus só seria aplicada caso não houvesse tal manifestação expressa ou tácita da lei que as partes desejassem aplicar. Pois bem, julgou a Corte que a as partes acordaram tacitamente pela lei francesa, uma vez que pactuaram livremente uma cláusula de exoneração, ilegal segundo a Lei de Nova York, porém lícita diante da lei francesa. $^{136}$

\footnotetext{
${ }^{134}$ Sobre os referidos autores, cf. ARAUJO, Nadia, Op. Cit., pp59-61.

${ }^{135}$ Tratava o caso de litígio acerca de contrato de transporte de mercadora que chegou ao seu destino avariada, envolvendo a American Trading Co. e a transportadora Quebec Steamship. A American Co. acionou a transportadora e seu capitão solidariamente para ressarcir-se do prejuízo, sendo que a transportadora alegou uma cláusula de irresponsabilidade, enquanto que a companhia norte-americana contra-argumentou pela nulidade da cláusula diante da Lei de Nova York, onde o contrato fora celebrado, havendo menção expressa no contrato das partes neste sentido.

${ }^{136}$ ARAUJO, Nadia, Op. Cit., p62.
} 
Nadia de Araujo demonstra que dos comentários ao caso referido acima, surgiram duas grandes posições acerca da autonomia da vontade. A primeira, chamada de concepção subjetivista, diz ser a designação da lei aplicável objeto de escolha totalmente e exclusivamente da vontade das partes contratantes, e apenas na ausência dessa escolha que se veria a escolha tácita, a vontade hipotética. Tem este nome a concepção por defender que a escolha da lei figura entre os direitos subjetivos. ${ }^{137}$ Já a segunda concepção é dita objetivista, por aduzir a ideia de que a lei não pode ser objeto de disposição das partes, que devem apenas se submeter a ela, aplicando a tese de que o juiz determina a lei, tendo por base a vontade das partes, mas esta resume-se na escolha do local do contrato. Destarte, nas palavras de internacionalista, escapa às partes "descartar determinadas normas aplicáveis aos contratos, tampouco elaborar um contrato que escape ao domínio da lei. ",138

Contudo, como a própria doutrinadora ressalta, tal divergência teórica perdeu muito de seu atrativo em face da evolução do direito convencional internacional, que permite expressamente a escolha da lei aplicável, convenções essas que têm força de lei, dando fimm na discussão entre subjetivistas e objetivistas:

\footnotetext{
"Nos tempos atuais, a discussão sobre a legitimação da autonomia da vontade perdeu muito de seu atrativo, na medida em que convenções internacionais permitiram expressamente essa faculdade às partes para a escolha da lei contratual. A influencia destes novos diplomas internacionais determinou a modificação paulatina da legislação interna da maioria dos países, permitindo-se expressamente a autonomia" ${ }^{139}$
}

Já no campo da commom law, a autonomia da vontade encontrou campo fértil para florescer, já que desde 1760 havia sendo aplicada nas cortes inglesas. O primeiro caso foi Robinson vs. Bland, em que a lei

\footnotetext{
${ }^{137}$ Ibidem, p50.

${ }^{138}$ Ibidem, pp63-64.

${ }^{139}$ Ibidem, p.52.
} 
inglesa foi aplicada por ser esta a desejada pelas partes. Disse Lord Mansfield:

\begin{abstract}
"The general rule established ex comitate et jure gentium is, that the place where the contract is made, and not where the action is brought, is to be considered in expounding and enforcing the contract. But this rule admits of an exception where the parties (at the time of making the contract) had a view to a different kingdom." 140
\end{abstract}

Ainda no séx. XIX desenvolveu-se a teoria do Proper Law, em que deve o julgador, no litígio, buscar a lei mais apropriada ${ }^{141}$ (daí a expressão “proper”). Nesta busca, o julgador também deve respeitar a intenção das partes evidenciada na lei que pretendem aplicar. Tal intenção, caso não esteja expressa no contrato, deverá ser presumida pelo juiz através das características do contrato e dos fatos relevantes concernentes a ele.

Ao estudar a matéria de conflito de leis nos EUA, outro país da commom law, impõe reconhecer, primeiramente, que a disciplina não trata exclusivamente de conflitos entre leis de outros países, abarcando também o conflito de leis entre estados da federação. Neste sentido, explica Nadia de Araujo:

\begin{abstract}
"na verdade, a matéria do conflito de leis não trata somente de casos internacionais, mas essencialmente do que chamaríamos de casos domésticos. As cortes americanas distinguem de forma tênue um caso internacional de um caso interestadual. Quando se estuda Conflict of Laws americano, sempre que há uma referência a um State, tanto pode ser na acepção de outro Estado da federação ou de um país estrangeiro. Também consideram foreign (estrangeira) a lei de outro estado, da mesma forma que fariam com a lei de outro país. Arriscaríamos dizer que a animosidade é maior para com as leis de outros estados, tidos como competidores, do que com as de um estado estrangeiro." 142
\end{abstract}

\footnotetext{
${ }^{140}$ Em tradução livre: "a regra geral estabelecida ex comitate et jure gentium é que o lugar onde o contrato é feito e não onde a ação é proposta, deve ser considerado na exposição e cumprimento do contrato. Mas esta regra admite uma exceção em que as partes (no momento da celebração do contrato) tinham em vista um reino diferente." (JOHNSTON, Robert, Party autonomy in contracts specifying foreign law, In: William \& Mary Law Review, vol. 7, No. 37, 1966, em: http://scholarship.law.wm.edu/wmlr/vol7/iss1/3).

${ }^{141}$ STRENGER, Irineu, "Direito Internacional Privado", São Paulo: LTr, 6 a ed., 2005, p606.

${ }^{142}$ ARAUJO, Nadia, Op. Cit., p77.
} 
Dito isto, temos em Joseph Story, como dito anteriormente, o primeiro expoente da matéria. Story defendeu a aplicação da lex loci contractus como regra geral para o conflito de leis, e a lex loci executionis no caso de contratos celebrados para execução em país estrangeiro. Seu sucessor em prestígio foi Joseph Beale, o célebre autor do Restatement First ${ }^{143}$, também advogou a lex loci contractus, por não deixar dúvidas sobre sua aplicação. ${ }^{144}$ Contudo, a doutrina evoluiu no sentido contrário e na época do Restatement 2nd a lex voluntatis já estava plenamente defendida pela comunidade jurídica. A compilação reformulada prevê em âmbito norte-americano a autonomia da vontade em sede de contratos internacionais em suas seções 186 e $187^{145}$.

Todavia, vale notar que no Restatement 2 nd não há espaço para a escolha de uma lei alienígena que não tenha qualquer relação com o contrato. É a conclusão que se tira do teor da alínea (2) do §187, onde se diz claramente que a lei estrangeira será aplicada a não ser que "a lei escolhida não tenha relação substancial com as partes ou a transação e não há outra

\footnotetext{
${ }^{143}$ Embora o Restatement 1st não seja um "código" de direito internacional privado, teve ampla aceitação na prática jurídica naquele país. A compilação feita pelo American Law Institute, encabeçada por Beale em 1934, representou um grande avanço na matéria. Para uma visão sobre o impacto desta publicação na jurisprudência norte-americana, v. RICHMAN, William, M. E RILEY, David, The First Restatement of Conflict of Laws on the Twenty-fifth anniversary of its sucessor: contemporary practice in tradicional courts, In: Maryland Law Review, Vol. 56, 1997. Disponível em: http://ssrn.com/abstract=1140308.

${ }^{144}$ ARAUJO, Nadia, Op. Cit., p70.

${ }^{145} \S 186$. - Applicable Law - Issues in contract are determined by the law chosen by the parties in accordance with the rule of $\S 187$ and otherwise by the law selected in accordance with the rule of $\S 188$.

$\$ 187$ - Law of the State chosen by the parties

(1) The law of the state chosen by the parties to govern their contractual rights and duties will be applied if the particular issue is one which the parties could have resolved by an explicit provision in their agreement directed to that issue.

(2) The law of the state chosen by the parties to govern their contractual rights and duties will be applied, even if the particular issue is one which the parties could not have resolved by an explicit provision in their agreement directed to that issue, unless either (a) the chosen state has no substantial relationship to the parties or the transaction and there is no other reasonable basis for the parties' choice, or

(b) application of the law of the chosen state would be contrary to a fundamental policy of a state which has a materially greater interest than the chosen state in the determination of the particular issue and which, under the rule of s 188 , would be the state of the applicable law in the absence of an effective choice of law by the parties.

(3) In the absence of a contrary indication of intention, the reference is to the local law of the state of the chosen law.
} 
base razoável para a escolha das partes". Em linhas gerais, são duas as regras estabelecidas pelo Restatement 2nd: as partes podem escolher livremente a lei a ser aplicada no contrato, e na falta desta escolha, aplica-se a lei do Estado com maiores elementos de contato. Todavia, em vista da recente alteração na lei de dois dos mais importantes Estados daquela Federação, a saber, Nova York e Califórnia, no sentido de permitir a escolha de qualquer lei, ainda que não haja elementos de contato, pode trazer alterações mais significativas no direito daquele país como um todo.

Digna de nota também é o tratamento dado à autonomia pelo direito convencional. O Regulamento n. 593, sobre Lei Aplicável para as obrigações contratuais, trata dos contratos internacionais em âmbito europeu. Este Regulamento substituiu a elogiada Convenção de Roma, datada de 1980. Vale dizer que uma das preocupações da Comunidade Europeia é a harmonização dos ordenamentos jurídicos de seus Estadosmembros, ${ }^{146}$ e para este fim, previu expressamente a autonomia na escolha da lei aplicável aos contratos internacionais, aplicando a lei com a qual o contrato tiver maior proximidade, critério este que se dá pela observância da prestação mais característica do contrato.

Em âmbito latino-americano os Tratados de Montevidéu (1889/90 e 1939/40) previram como regra de conexão a lex loci executionis, isto é, a lei do local de execução do contrato. Por conseguinte, o Código Bustamente, datado de 1928 e ratificado pelo Brasil, adotou a regra da lex celebrationis de modo parcial. Definiu em seu art. 186 que a lei aplicável será a comum às partes, e na ausência da mesma, a do lugar onde foi celebrado o contrato. Por outro lado, já a Convenção do México, fruto dos trabalhos da CIDIP V, consagrou a autonomia ampla para a escolha, conforme salienta Nadia de Araujo:

"no que diz respeito à lei aplicável, contemplou a convenção como regra geral o princípio da autonomia da vontade, quase na

${ }^{146}$ ARAUJO, Nadia. Op. Cit., p146. 
mesma forma estabelecida pela Convenção de Roma, hoje Regulamento n. 593, aceitando, inclusive, o dépeçage voluntário, a escolha de uma lei sem vínculo com o contrato, a possibilidade de sua modificação posterior, e a admissão da escolha tácita, quando evidente."

Não obstante a posição avançada da Convenção do México, a mesma ainda não foi internalizada pelo ordenamento pátrio. A adoção do texto convencional seria um valiosa ferramenta para superar a problemática do art. $9^{\circ}$ da LINDB, o qual abordaremos em seguida.

Por fim, fazemos referência aos Princípios do UNIDROIT para os Contratos Internacionais, datados de 1994, representam o que há de mais vanguardista em matéria de direito internacional privado. Elaborados pelo Instituto para Unificação do Direito Privado, cuja criação se deu em 1926, visam não somente servir à comunidade jurídica internacional como direito convencional, mas igualmente como fonte a ser aplicada pelas partes como norma substantiva em contratos, bem como à julgadores afim de resolver conflitos. Os Princípios compõem-se de 120 artigos e são totalmente $a$ nacionais, prevendo o princípio da autonomia da vontade, já que dependem de sua aplicação. Com efeito, os princípios do UNIDROIT apenas podem ser aplicados, entre nós, com a conjugação de uma cláusula de arbitragem nos contratos, tanto internos quanto internacionais, uma vez que a regra de conexão brasileira não prevê a autonomia, e mesmo que assim o fosse, esta se daria por um direito nacional e não desnacionalizado, como os Princípios. ${ }^{148}$

\footnotetext{
${ }^{147}$ ARAUJO, Nadia. Op. Cit., p194.

${ }^{148}$ Neste sentido, ensina Lauro Gama Jr.: "o emprego dos Princípios como direito aplicável ao contrato, por juízes e tribunais judiciais brasileiros, enfrenta os obstáculos derivados do caráter estatal de tais autoridades, que lhes conduz, no exercício da jurisdição, a naturalmente identificar o fenômeno jurídico ao fenômeno estatal (...). Em ordens jurídicas como a brasileira, de tradição civilista e ibérica, o juiz possui natural apego ao direito estatal, e procede, tradicionalmente, em estrita vinculação à lei positiva, inclusive no que tange à solução dos conflitos de leis no espaço. Conforme essa visão dominante, quando as regras conflitantes admitem a eleição do direito aplicável ao contrato, tal indicação deve restringir-se ao direito estrangeiro estatal ou ao direito internacional de origem convencional, vedando-se que a escolha recaia sobre um direito transnacional, sem liames com os sistemas criados por Estados nacionais. (...) A situação muda radicalmente quando se trata da aplicação dos Princípios do UNIDROIT por árbitros internacionais, que não são funcionários públicos - embora a eles se equiparem, para certos fins,
} 


\title{
2.2 Autonomia no DIPr pátrio e sua evolução
}

Conforme dissemos anteriormente, Lauro Gama e Souza Jr. analisa o tratamento da autonomia da vontade em sede de contratos internacionais no direito brasileiro como descrevendo um "movimento pendular". Diz o jusinternacionalista:

\begin{abstract}
"Das autorizações legislativas concebidas no século XIX, sob influência do liberalismo, passando pela sua eliminação, em pleno regime ditatorial, até a consagração expressa na lei de 1996 (Lei de Arbitragem), o regime da autonomia da vontade experimentou certamente um percurso acidentado, e de poucos registros jurisprudenciais." 149
\end{abstract}

O exame da autonomia da vontade foi empreendido, primeiramente, por Pimenta Bueno e Teixeira de Freitas, ambos lecionando ainda no séc. XIX. Pimenta Bueno, em sua obra de 1863 demonstra-se contrário à autonomia na escolha da lei aplicável, dando ao termo o sentido apenas de liberdade de contratar (no sentido de avençar, celebrar o contrato) havendo a lei aplicável ser definida pela regra do lex loci contractus, e quando o contrato for executado no exterior, pela lex loci executionis. ${ }^{150}$

Já Teixeira de Freitas, profundamente influenciado por Savigny, ${ }^{151}$ aproximou-se do pensamento do jurista alemão no sentido de perquirir o "lugar" do contrato em seu cumprimento, adotando para tal, a lex loci executionis como lei aplicável em relação aos seus efeitos. A evolução na obra de Teixeira de Freitas revela-se no fato do autor entender ser cabível

no exercício de suas funções -, nem se encontram 'presos' a nenhuma ordem jurídica em particular, o que lhes permite, inclusive, julgar por equidade quando autorizado pelas partes." (SOUZA JR., Lauro Gama. Op. Cit., pp429-438).

${ }^{149}$ SOUZA JR., Lauro Gama e, "Autonomia da vontade nos contratos internacionais no Direito Internacional Privado brasileiro: Uma leitura constitucional do artigo $9^{\circ}$ da Lei de Introdução ao Código Civil em favor da liberdade de escolha do direito aplicável", In: TIBURCIO, Carmen e BARROSO, Luís Roberto (Org.) "O direito internacional contemporâneo: estudos em homenagem ao professor Jacob Dolinger”, Rio de Janeiro: Renovar, 2006, p601.

${ }^{150}$ BUENO, José Antonio Pimenta, “Direito Internacional Privado: aplicação de seus princípios com referência ás leis particulares do Brazil", Rio de Janeiro: Typographia Imp. e Const. de J. Villeneuve, 1863, pp.112-113.

${ }^{151}$ SAMTLEBEN, Jürgen, Op. Cit., p264; e SOUZA Jr., Lauro Gama, Op. Cit., p602. 
às partes a escolha do domicílio do contrato, conforme consta no seu Esboço. Neste sentido, ensina Jürgen Samtleben:

\begin{abstract}
"as regras do Esboço sobre contratos expressam uma ideia bem moderna que nessa forma não se encontra na obra de Savigny. Enquanto este procura, em primeiro lugar, o foro especial e a lei territorial para cada obrigação contratual, Freitas vê claramente que o decisivo é a lei do contrato. É esta ideia que o leva consequentemente a reconhecer a autonomia das partes na determinação dessa lei." ${ }^{152}$
\end{abstract}

Entendem também Irineu Strenger e Lauro da Gama e Souza Jr. que Teixeira de Freitas, em seu entendimento sobre o domicílio do contrato, prevê a autonomia da vontade, conforme o art. 1.965 do Esboço ${ }^{153}$.

Clóvis Bevilaqua, por sua vez, defendeu a autonomia das partes para a escolha do direito estrangeiro, devendo haver o respeito aos limites naturais na forma da lei. Para o autor, ocorre no caso o fenômeno chamado dépeçage, em que leis distintas são aplicadas ao mesmo contrato. Assim ocorre pois em matéria de capacidade e execução, impera a lei do local da celebração ${ }^{154}$, ao passo que na substância e conteúdo, abre-se a livre escolha. ${ }^{155}$ Em sentido totalmente diverso é a posição do grande Pontes de Miranda. Para o doutrinador, a cogência das leis impede uma ideia de autonomia da vontade, uma vez que ao determinar a faculdade de escolha de outra lei, esta lei autorizadora não perde sua imperatividade. Em outras palavras, sua imperatividade é cumprida ao facultar que torne-se dispositiva. Por fim, conclui Pontes de Miranda:

"afastada a autonomia das partes como princípio fica de pé: a)
que há Estado competente para dizer a lei aplicável às obrigações
(contratuais, por declaração unilateral de vontade) e b) que, no

\footnotetext{
${ }_{152}^{152}$ Ibidem, p265.

153 "Finalmente, quanto à substância dos contratos (pois o "Esboço" não foi às sucessões), adotou, amplamente, o princípio da lei do lugar da execução (art. 1.962). Define-o no art. 1.963 e ressalva o princípio da autonomia de vontade na forma de domicílio especial (art. 32) no art. 1.965." (STRENGER, Irineu, Op. Cit., p267) e SOUZA Jr., Lauro Gama, Op. Cit., p602.

154 "A capacidade para contrair obrigações voluntárias, quer sejam convencionais, quer unilaterais, depende da lei pessoal das partes. A forma do ato" (BEVILAQUA, Clóvis, "Princípios elementares de direito internacional privado". Rio de Janeiro: Freitas Bastos, $2^{\mathrm{a}}$ ed., 1934, p.345).

155 "A verdadeira opinião parece-me aquela que, em primeiro lugar, atende á autonomia da vontade.” (BEVILAQUA, Clóvis, Op. Cit., p347.)
} 
caso de dois Estados interessados, existe um problema de pesquisa da lei a que se deve obedecer. Este problema ou se resolve pela observância sincrônica das leis dos Estados da nacionalidade dos obrigados, ou pela adoção, artificial, de um princípio de ajustação, no qual finalmente teríamos a lex contractus." $" 156$

Todos os autores acima citados escreveram sob os auspícios do Código de 1916, e com ele, sua Introdução. O art. 13 da referida lei, na opinião de Edgar Carlos de Amorim ${ }^{157}$ e outros autores ${ }^{158}$ "preferiu o princípio da autonomia da vontade" para reger as obrigações, em razão do teor de seu caput, verbis:

Art. 13. Regulará, salvo estipulação em contrário, quanto á substância e aos efeitos das obrigações, a lei do lugar, onde forem contraídas.

Parágrafo único. Mas sempre se regerão pela lei brasileira:

I. Os contratos ajustados em países estrangeiros, quando exequíveis no Brasil.

II. As obrigações contraídas entre brasileiros em país estrangeiro. III. Os atos relativos a imóveis situados no Brasil. IV. Os atos relativos ao regime hipotecário brasileiro. (grifou-se)

Acerca deste dispositivo, não obstante a discussão do caráter imperativo dos itens I, II e III de seu parágrafo único, a doutrina estava pacificada no sentido de permitir o art. 13 da Introdução de 1917 a autonomia das partes. ${ }^{159}$ A regra da lex loci contractus seria utilizada apenas se as partes não houvessem acordado lei específica. Contudo, com a

\footnotetext{
${ }^{156}$ PONTES DE MIRANDA apud ARAUJO, Nadia, Op. Cit., p105.

${ }^{157}$ AMORIM, Edgar Carlos de, Op. Cit., p74.

${ }^{158}$ Neste mesmo sentido, DEL'OLMO, Florisbal de Souza, Op. Cit., p134. Também Luiz Alberto de Souza e Silva comentando o referido art. da Lei de Introdução de 1917, declara: "O objeto do contrato ou substância da obrigação deve estar subordinado à vontade das partes e aos preceitos imperativos ou de ordem pública das leis pessoais dos pactuantes." (SOUZA E SILVA, Luiz Alberto de, Direito Internacional Privado: Lei de Introdução ao Código Civil, Rio de Janeiro: Lumen Juris, 2000, p38), assim como Lauro da Gama e Souza Jr., para quem: "o artigo 13 da Introdução ao Código Civil (1996) permitia a eleição do direito aplicável ao contrato”. (SOUZA Jr, Lauro da Gama e, Op. Cit., p604.

${ }^{159}$ Bevilaqua criticou as exceções trazidas pelo parágrafo único do art. 13 em razão de sua posição amplamente favorável à autonomia, ao passo que Eduardo Espínola, embora favorável ao princípio, entendia ser a hipótese do parágrafo único de caráter imperativo, não podendo as partes afastarem-se das limitações trazidas pelo legislador. Neste sentido, a expressão "salvo estipulação em contrário", deve ser entendida "quando estipulação em contrário possa ter lugar". Para Haroldo Valladão, a lei escolhida pelas partes devia ser aplicada na íntegra, tanto em disposições imperativas quanto facultativas. (ARAUJO, Nadia, Op. Cit., p108).
} 
promulgação do Decreto-Lei no. $4.657 / 1942^{160}$, portanto, uma nova Introdução ao Código Civil, tal cenário mudou radicalmente. $\mathrm{O}$ art. 13 da antiga Introdução não foi mantido pelo Decreto-Lei, sendo agora as obrigações reguladas pelo art. 9 da LICC (atualmente chamada de LINDB "Lei de introdução às normas do direito brasileiro" em virtude da alteração feita pela Lei no. 12.376/2010), que por sua vez confere outro tratamento à matéria. Diz o art. 9 da LINDB:

Art. 9. Para qualificar e reger as obrigações, aplicar-se-á a lei do país em que se constituírem.

Parágrafo único. Mas sempre se regerão pela lei brasileira:

$\S 1^{\circ}$ Destinando-se a obrigação a ser executada no Brasil e dependendo de forma essencial, será esta observada, admitidas as peculiaridades da lei estrangeira quanto aos requisitos extrínsecos do ato.

$\S 2^{\circ}$. A obrigação resultante do contrato reputa-se constituída no lugar em que residir o proponente.

Nota-se que o artigo em exame, embora tenha preservado a regra da lex loci contractus, eliminou a expressão "salvo estipulação em contrário" contida no art. 13 da antiga Lei de Introdução. Neste sentido caminha também a insipiente jurisprudência brasileira sobre a matéria. ${ }^{161}$ Tal

\footnotetext{
${ }^{160}$ Segundo a lição de Luiz Alberto de Souza e Silva, a Segunda Grande Guerra e consequente declaração de guerra do Brasil à Alemanha e Itália promoveram uma reforma em diversos institutos do direito internacional privado segundo o regramento anterior. Segundo o autor, "O Decreto-lei no. 4.657 , de 4 de setembro de 1942, promulgado às pressas e sem qualquer discussão legislativa ou uma exposição justificada de motivos, alterou alguns princípios estruturais de nosso direito internacional privado". (SOUZA E SILVA, Luiz Alberto de, Op. Cit., p69). Cogitamos se Haroldo Valladão pensou também desta maneira ao defender a manutenção da autonomia da vontade mesmo diante da omissão do princípio pela nova Lei de Introdução, já que segundo o autor este sempre esteve presente no direito internacional privado brasileiro.

${ }^{161}$ No REsp. 97099, datado de 15.06.1998 e relatoria pelo Min. Eduardo Riberto, o STJ aplicou a lex loci contractus num caso complexo sobre contrato de corretagem. Entendeu o Superior Tribunal que o contrato fora concluído no Brasil, e portanto, devendo aplicar-se a lei brasileira ao caso. A $2^{\text {a }}$ Câmara Cível do TJDFT num caso de dívida de jogo aplicou a regra de conexão do caput da LINDB por entender sê-la norma de ordem pública. Encontra-se o seguinte na ementa do acórdão: "a própria Lei de Introdução ao Código Civil limita a interferência do direito alienígena, quando houver afronta à soberania nacional, à ordem pública e aos bons costumes. A ordem pública, para o direito internacional privado, é a base social, política e jurídica de um estado, considerada imprescindível para a sobrevivência de um Estado, que pode excluir a aplicação do direito estrangeiro. Considerando a antinomia na interpretação dos dois sistemas jurídicos, ao passo que se caracterizou uma pretensão de cobrança de dívida inexigível em nosso ordenamento, tem-se que houve enriquecimento sem causa por parte do embargante, que abusou da boa-fé da embargada, situação essa repudiada pelo nosso ordenamento, vez que atentória à ordem pública, no sentido que lhe dá o direito internacional privado.” EIC. 4492197, Rel. Wellington Medeiros, dj. 14.10.1998. A 18 Câmara Cível do TJRJ, na Apelação no. 0009243-68.2002.8.19.0203, de relatoria do Des. Pedro Raguenet em 09.03.2010 se pronunciou também pela aplicação da lex loci
} 
redação causou uma discussão na doutrina brasileira, havendo três vertentes doutrinárias sobre o assunto, como ensinam Lauro da Gama e Nadia de Araujo. ${ }^{162}$

\section{A primeira, podendo ser chamada de realista, é defendida por} aqueles que não encontram base concreta no ordenamento para justificar a autonomia da vontade. Entre estes temos João Grandino Rodas ${ }^{163}$, Nadia de Araujo $^{164}$, Maria Helena Diniz ${ }^{165}$, Amilcar de Castro ${ }^{166}$ e Campos Batalha. $^{167}$

\footnotetext{
contractus, como se segue: "Vale acrescentar que a própria lei civil de regência ao tempo do contrato (o Código Civil de 1916) expressamente previa esta possibilidade de aplicação do direito alienígena, na forma do contido no art. 9o da LICC, que reza que "para qualificar e reger as obrigações, aplicar-se-á a lei do país em que se constituírem".

${ }^{162}$ SOUZA Jr, Lauro da Gama e, Op. Cit., p605 e ARAUJO, Nadia, Op. Cit., 119.

163 "Perante o caput taxativo do art. $9^{\circ}$ da Lei de Introdução vigente, não se pode afirmar a existência da autonomia da vontade para a indicação da norma aplicável, no Direito Internacional brasileiro." (RODAS, João Grandino, "Elementos de conexão do Direito Internacional Privado brasileiro relativamente às obrigações contratuais". In: RODAS, João Grandino (coord.) et al. Contratos internacionais, São Paulo: Revista dos Tribunais, $3^{\text {a }}$ ed., 2002, p.59

164 "Para nós, no estágio atual da legislação brasileira, a escolha da lei aplicável a um contrato internacional, nos moldes reconhecidos atualmente na comunidade internacional, não encontra amparo na legislação vigente". (ARAUJO, Nadia, Op. Cit., p120.)

${ }^{165}$ DINIZ, Maria Helena, Lei de introdução ao Código Civil interpretada, São Paulo: Saraiva, $1998, \mathrm{p} 256$.

${ }^{166} \mathrm{O}$ autor, após apresentar uma síntese das diferentes posições sobre o critério da lei a ser aplicável nas obrigações internacionais, inicia seu exame da autonomia da vontade fazendo uma distinção entre esta e o conceito de submissão voluntária, que na opinião do autor é a ideia de Savigny. Destarte, com o termo autonomia da vontade, nas palavras do autor, "o que se pretende afirmar é que as partes, realizando seus contratos no lugar onde normalmente costumam realizalos, se o fato for anormal, poderão escolher, para apreciá-lo, qualquer direito com que esteja em referência, nacional ou estrangeiro. Em vez, portanto, de ser o direito primário indicado pela norma de direito internacional privado, fica sendo escolhido livremente pelas partes, cuja vontade se encontrará, então, sobreposta a essa norma." Por fim, Amilcar de Castro encerra sua oposição nos seguintes termos: "Em direito, não existe a suposta autonomia da vontade, pois o que há sempre é liberdade concedida pelo direito, e por este limitada." E ainda, "não existe, portanto, a imagina autonomia da vontade em direito internacional privado: o objeto próprio da vontade das partes é a escolha do lugar onde queiram realizar o contrato, e não a escolha do direito." Contudo, $\mathrm{o}$ autor reconhece que o próprio direito permite às partes uma certa autonomia privada naquilo que não for regulado por norma imperativa. Acerca da Lei de Introdução de 1942, Amilcar escreve: "o direito positivo brasileiro (...) consagra a doutrina do ius loci contractus. O art. $9^{\circ}$ da Lei de Introdução, para qualificar e reger as obrigações, manda observar o direito do país em que se constituírem; portanto, se se constituírem no Brasil, o direito brasileiro será observado quanto à forma e quanto ao fundo (ius fori)". CASTRO, Amilcar de, Direito Internacional Privado, Rio de Janeiro: Forense, $5^{\text {a }}$ ed. aum. e atualizada com notas de rodapé por Osiris Rocha, 2004, Pp443445.

${ }^{167}$ Nadia de Araujo explicita o pensamento do autor, para quem seria inaceitável a escolha da lei aplicável diante dos contornos trazidos pela Introdução de 1942. (ARAUJO, Nadia, Op. Cit., p112).
} 
No outro extremo, encontra-se a vertente amplamente favorável ao princípio, tendo Haroldo Valladão e Jacob Dollinger como seus expoentes. Valladão argumenta que embora a LINDB (até então "LICC") não fale expressamente do princípio, este permaneceu na ordem jurídica brasileira. Ademais, a expressão "reputa-se" deve ser entendida na mesma forma que a "salvo estipulação em contrário" da Lei de Introdução anterior. ${ }^{168}$ Sobre tal posicionamento, escreve Jacob Dolinger, defensor também do princípio $^{169}$ :

\begin{abstract}
"causa-me tristeza o fato de que os jovens juristas não tenham compreendido o alcance da visão do grande jusinternacionalista pátrio, o mestre Haroldo Valladão, que, com segurança e argumentação lógica, demonstrou que o artigo $9^{\circ}$ da LICC de 1942 pode e deve ser interpretado como favorável à liberdade de contratar a lei aplicável, por força do disposto no seu parágrafo $2^{\circ}$ e da regra do artigo 42 do Código Civil brasileiro de 1916. Que colegas de Valladão, seus contemporâneos, tenham expressado opinião diferente, quando a matéria ainda era debatida em outros países entendo perfeitamente. Mas que depois da avalanche de convenções internacionais no sentido da autonomia da vontade contratual para escolha da lei aplicável, e do consenso internacional - doutrinário e jurisprudencial - no mesmo sentido, e depois de o Brasil ter assinado a Convenção do México de 1994 que determina a regência do contrato pela escolhida pelas partes, ainda haja estudiosos na academia e burocratas na diplomacia que, mesmo à luz da evolução do Direito Internacional Privado no mundo todo, não confiem na irrespondível argumentação do professor Valladão, é realmente decepcionante." 170
\end{abstract}

Fora destes dois extremos, há ainda uma terceira vertente, de caráter conciliador, que considera a existência da autonomia da vontade, contudo,

\footnotetext{
${ }^{168}$ ARAUJO, Nadia, Op. Cit., p109. Lauro da Gama e Souza Jr traz a citação do mestre Valladão: “A nova L.I. de 1942, art. $9^{\circ}$, não se referiu à autonomia da vontade. Era expressão proibida no regime ditatorial de que padecia o Brasil, e que explicou, também, a ausência do foro do contrato ou de eleição no Cód. Proc. Civil, de 1939-40, promulgado no mesmo clima. Mas um princípio básico, qual o da autonomia, não podia desaparecer, assim, por omissão." (VALLADÃO, Haroldo apud SOUZA Jr, Lauro da Gama e, Op. Cit., p607).

169 "No direito internacional das obrigações impera a regra lex loci contractus, dividindo-se as legislações do DIP entre as que aplicam a lei do país em que a obrigação foi contraída e aqueles que indicam a competência da lei do país em que ela deve ser cumprida. Soberana, universalmente respeitada, a autonomia da vontade, que permite às partes eleger contratualmente a lei aplicável" (DOLINGER, Jacob apud SOUZA JR, Lauro da Gama e, Op. Cit., p607).

${ }^{170}$ DOLINGER, Jacob, "O Direito Internacional e a sua aplicação pelo Direito Brasileiro: atualidades e perspectivas - perspectivas do Direito Internacional Privado". In: MENEZES, Wagner, Op. Cit., p880-881. Em que pese o enorme peso da lição de Valladão, e por conseguinte, a opinião de Dolinger sobre a mesma, Lauro da Gama e Souza Jr., comentando a fala de Dolinger diz que os referidos argumento não são, à luz do contexto da LICC), "irrespondíveis", bem como não oferecem a esperada segurança jurídica. (SOUZA Jr, Lauro da Gama e, Op. Cit., p608).
} 
aplicada apenas indiretamente, restringindo-se às normas de caráter supletivo. Entre os defensores desta vertente encontram-se Luís Olavo Baptista $^{171}$, Oscar Tenório ${ }^{172}$, Serpa Lopes e Irineu Strenger ${ }^{173}$.

Com efeito, diante da atual redação do art. $9^{\circ}$ da LINDB e sua omissão expressa sobre o exercício da autonomia, a maior parte da comunidade jurídica, como visto acima, expressa seu ceticismo uma vez que o Art. $9^{\circ}$ da referida lei prevê, em seu texto, unicamente a lex loci contractus como norma definidora da lei a ser aplicada. Visando por um fim nesta discussão, Lauro da Gama e Souza Jr. propõe a reinterpretação do referido dispositivo da LINDB. Segundo o doutrinador, a análise do art. $9^{\circ}$ à luz da Constituição da República "pode revelar os fundamentos e a possibilidade, entre nós, da eleição do direito aplicável à contratação internacional." ${ }^{174}$ Pretende o doutrinador, trazendo a aplicação das normas constitucionais à discussão, oferecer elementos sólidos para a defesa do exercício da autonomia da vontade através da vinculação à matéria de direitos e garantias fundamentais expostos na CRFB, demonstrando que o direito internacional privado brasileiro "não contém vedação à escolha da lei aplicável ao contrato internacional, e, para além disso, que o ordenamento jurídico-constitucional dá amplo suporte à autonomia da vontade conflitual". 175

A constitucionalização da discussão sobre a lei aplicável encontra assento uma vez que a autonomia da vontade é uma liberdade fundamental assegurada pela CRFB, e sendo este um direito fundamental, não pode ser restringida sem previsão legal expressa, quanto menos uma interpretação, na visão do autor, desproporcional do art. $9^{\circ}$ da LINDB. O caráter de direito fundamental da autonomia da vontade decorre de um dos fundamentos

\footnotetext{
${ }^{171}$ BAPTISTA, Luiz Olavo, Dos contratos internacionais - uma visão teórica e prática, São Paulo: Saraiva, 1994, pp48-49.

${ }^{172}$ Para Oscar Tenório a Introdução de 1942 deu fim à discussão, uma vez que o teor do art. $9^{\circ}$ não abriria espaço para uma teoria da autonomia da vontade. (CITAR TENÓRIO, VOLUME II)

${ }^{173}$ STRENGER, Irineu, Op. Cit., p658.

${ }^{174}$ SOUZA Jr, Lauro da Gama e, Op. Cit., p608.

${ }^{175}$ Ibidem, p611.
} 
básicos do Estado de Direito: o princípio da legalidade. Este princípio, por sua vez aplicado ao direito privado constitui a cláusula geral de liberdade, positivada com assento constitucional no rol de direito fundamentais, por força do art. 5, II que diz "ninguém será obrigado a fazer ou deixar de fazer alguma coisa senão em virtude de lei”. Tem-se aí a base constitucional para a autonomia da vontade, sem a qual "o sujeito de direito, embora formalmente investido de titularidade jurídica, nada mais seria que um simples instrumento a serviço do Estado". ${ }^{176}$ Sendo uma das facetas dos direitos fundamentais o caráter de direitos de defesa, tais garantias apenas podem ser restringidas através de veículos específicos, dentre eles chamada reserva legal simples, i.e., previsão em lei, como a hipótese da autonomia privada (art. $5^{\circ}$, II da CRFB). Destarte, aplicada tal noção à escolha da lei aplicável, por ser expressão da autonomia, apenas pode ser proibida via norma legal expressa. Diz Lauro da Gama:

\footnotetext{
"não havendo no ordenamento brasileiro lei que proíba o gozo dessa liberdade, será inconstitucional (e, portanto, inválida) qualquer restrição ao exercício da autonomia da vontade conflitual deriva de uma interpretação extensiva do artigo 9o, caput, da LICC." 177
}

Prossegue o jusinternacionalista argumentando que toda e qualquer restrição a direitos fundamentais devem ser justificadas à luz do princípio da proporcionalidade, preceito este que se aplicado ao exame da questão revela a desproporcionalidade da restrição por mera omissão do texto legal, beneficiando um interesse que sequer tem status constitucional, qual seja, a aplicação da lex contractus. ${ }^{178}$ Ademais, sendo a interpretação constitucional, nas palavras de Sepúlveda Pertence, "controle de constitucionalidade que encontra o limite de sua utilização no raio das possibilidade hermenêuticas de extrair do texto uma significação normativa harmônica com a Constituição”, ${ }^{179}$ esta deve ser utilizada para conferir ao

\footnotetext{
${ }^{176}$ Ibidem, p614.

${ }^{177}$ Ibidem, p617.

${ }^{178}$ Ibidem, p621.

${ }^{179}$ STF, ADIn 3.046-SP, Rel. Min. Sepúlveda Pertence, dj. 28.05.2004
} 
dispositivo infraconstitucional a realização, na maior profundidade, do exercício da garantia fundamental da liberdade. Por fim, trazemos à tela a síntese feita pelo próprio doutrinador de sua proposta:

“(i) o artigo $9^{\circ}$ LICC, interpretado conforme a Constituição Federal, não proíbe a eleição, pelas partes, do direito aplicável ao contrato internacional, pois tal escolha repousa na autonomia privada, que deriva da cláusula constitucional de liberdade, inscrita dentre os direitos e garantias fundamentais, e se sujeita ao princípio da legalidade (artigo $5^{\circ}$, II da Constituição);

(ii) admitir no artigo $9^{\circ}$ da LICC uma condição vedatória não prevista no ordenamento positivo, implica igualmente em afronta à proporcionalidade em sentido estrito, eis que impõe sacrifício desproporcional à garantia de liberdade da pessoa, em favor de regra definidora do direito aplicável ao contrato (lex loci celebrationis) despida de qualquer conteúdo constitucionalmente relevante;

(iii) não havendo no ordenamento positivo norma proibitiva do exercício da autonomia da vontade em matéria de contratos internacionais, a autonomia privada (artigo $5^{\circ}$, II, da Constituição), que se irradia objetiva e expansivamente por todo o sistema do direito privado, assegura, por si só, a validade e eficácia da escolha do direito aplicável feita pelas partes, desde que observados os limites impostos pelas normas imperativas e pela ordem pública."

Permitimo-nos pensar que a atual discussão doutrinária poderia ser sanada eficazmente com a adoção, pelos nossos tribunais, da interpretação à luz da Constituição do art. $9^{\circ}$ da Lei de Introdução, conforme defendida por Lauro da Gama e Souza Jr. Por ser o meio idôneo para tanto, o ajuizamento de uma arguição de descumprimento de preceito fundamental (ADPF) sobre a matéria levaria a Suprema Corte de nosso país a se pronunciar sobre o assunto, que tanto carece de jurisprudência para enriquecer o estudo da matéria. ${ }^{181}$

Diante dos elementos acima referidos, hodiernamente ocorre uma estranha situação na ordem jurídica internacional privada brasileira sobre o exercício da autonomia da vontade ou sua negação: não é natureza

\footnotetext{
${ }^{180}$ SOUZA Jr, Lauro da Gama e, Op. Cit., pp622-623.

181 "Poder-se-ia dizer até que a questão da autonomia da vontade - como se vê nos poucos casos encontrados - jamais foi enfrentada diretamente.” (ARAUJO, Nadia, Op. Cit., p271.)
} 
contratual que abre espaço à ela, antes, é o modo de resolução de conflitos que irá garantir, plenamente, seu exercício. Referimo-nos ao instituto da arbitragem, ao qual passamos a examinar. 


\section{O instituto da Arbitragem}

$\mathrm{Na}$ análise do movimento pendular da autonomia da vontade, encontramos na arbitragem, seja em sua expressão interna quanto internacional, seu movimento mais proeminente, uma vez que encontra, nela, sua razão de ser. A arbitragem é espécie do gênero das $A D R-$ Alternative Dispute Resolution, que juntamente com os institutos da mediação e conciliação ${ }^{182}$, constitui-se método alternativo de resolução de conflitos $^{183}$, regulado entre nós pela Lei n. 9.307/1996, a Lei de Arbitragem (LArb).

\subsection{Antecedentes históricos}

$\mathrm{O}$ instituto da arbitragem goza de grandes antecedentes históricos. Os professores Jacob Dolinger e Carmen Tiburcio, em obra sobre o instituto, remontam o uso da arbitragem, ainda que de forma primitiva, ao

\footnotetext{
${ }^{182}$ Vale dizer que ainda que sejam espécies do mesmo gênero, os institutos guardam proximidades e claras distinções que não podem ser confundidas. A principal diferença entre os institutos, segundo Fouchard, Gaillard e Goldman reside no seguinte fato: "the conciliator and the mediator endeavor to bring together the parties to a dispute but, unlike the arbitrator, they do not have the power to impose a solution on the parties.". Em tradução livre: "o conciliador e o mediador trabalham para reunir as partes em um litígio, mas ao contrário do árbitro, eles não têm o poder de impor às partes uma solução." (FOUCHARD, Phillipe; GAILLARD, Emmanuel; GOLDMAN, Bertold. Fouchard Gaillard Goldman on international arbitration, Haia: Kluwer Law International, 1999, p11, §11). Destarte, a arbitragem é heterocomposição, ao passo que a mediação e a conciliação são espécies de autocomposição. Em suma, tanto na mediação, quanto na conciliação, a solução do conflito se dá por meio de um acordo entre as partes, buscando ao máximo uma situação "ganha-ganha" para ambas as partes. Contudo, no instituto da arbitragem a solução do conflito se dá através de uma sentença arbitral (também chamado de laudo), geralmente numa situação "perde-ganha". Vale também notar que diversos órgãos importantes que se debruçam sobre as $A D R$ têm regras específicas sobre os institutos, fazendo uma clara distinção entre eles. À título de ilustração, as regras de arbitragem da UNCITRAL (Comissão das Nações Unidas para o Direito Comercial Internacional) datam de 1976 (revistas no ano de 2010), enquanto que as de conciliação datam de 1980. Da mesma forma, câmaras arbitrais de relevo tais como a francesa CCI (Câmara de Comércio Internacional) e o ICSID (Câmara Internacional para Resolução de Conflitos em matéria de investimentos), fazem uma clara distinção entre a arbitragem e o procedimento de conciliação, deixado como opcional às partes. Para o texto do procedimento arbitral da UNCITRAL cf. http://www.uncitral.org/pdf/english/texts/arbitration/arbrules-revised/arb-rules-revised-2010-e.pdf

${ }^{183}$ Como bem aponta José Maria Rossani Garcez, "A arbitragem consiste no método parajurisdicional mais complexo e certamente o mais efetivo para solução de conflitos de natureza privada que possam ser objeto de disposição pelas partes mediante convenção privada" (GARCEZ, José Maria Rossani (Coord.), "Arbitragem na era da globalização". Rio de Janeiro: Forense, $2^{\mathrm{a}}$ ed., 1999, p1).
} 
período bíblico dos patriarcas de Israel: Abraão, Isaque e Jacó. ${ }^{184}$ Com efeito, na ausência do Estado como ente solucionador de conflitos, a arbitragem já era amplamente praticada pelos particulares. ${ }^{185} \mathrm{O}$ instituto é tão antigo que precede a própria existência do juiz estatal e do próprio legislador. ${ }^{186}$ Nas palavras de Pedro Batista Martins, a arbitragem foi utilizada "pelos povos desde a mais remota antiguidades, quando a desconfiança recíproca e as diferenças de raça e religião tornavam

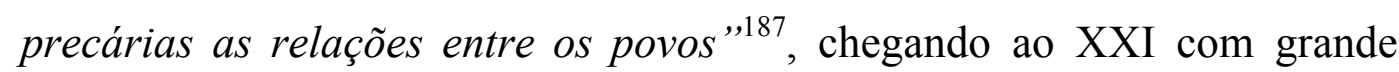
interesse por parte da comunidade jurídica.

Em nosso país, a arbitragem (gize-se, em sua expressão de direito internacional público ${ }^{188}$ ) conta com uma longa tradição de utilização,

${ }^{184}$ DOLINGER, Jacob e TIBURCIO, Carmen, "Direito Internacional Privado: arbitragem comercial internacional". Rio de Janeiro: Renovar, 2003, pp6-17.

${ }^{185}$ Como salienta Luiz Olavo Baptista: "Historicamente a arbitragem antecede a existência de juizados estatais. É a mais antiga das formas de distribuição de justiça". O professor titular de DIPr da USP cita ainda Hodsworth, doutrinador britânico, para quem: "A prática da arbitragem, assim, deriva, por assim dizer, naturalmente a organismos primitivos de direito; e depois que os tribunais foram estabelecidos pelo estado e que o recurso a eles tornou-se o método natural de resolver disputas, a prática continua porque as partes em uma disputa desejam resolvê-la com menos formalidade e despesa que a envolvida com o recurso dos tribunais" (BAPTISTA, Luiz Olavo, prefácio, In: GARCEZ, José Maria Rossani (Coord.), "Arbitragem na era da globalização". Rio de Janeiro: Forense, $2^{\mathrm{a}}$ ed., 1999, IV.

${ }^{186}$ MARTINS, Pedro Batista, "Arbitragem através dos tempos: obstáculos e preconceitos à sua implementação no Brasil" In: Arbitragem na Era da Globalização, GARCEZ, José Maria Rossani (Coord.), Rio de Janeiro: Forense, $2^{\text {a }}$ ed., 1999, p35.

${ }^{187}$ A história da arbitragem remonta à superação da primitiva autotutela. Os conflitos passaram a ser resolvidos pelo ancião da tribo, indivíduo escolhido pelas partes para dar uma solução ao conflito de interesses. Este terceiro imparcial aplicava os costumes e princípios predominantes à época, uma vez que não havia direito positivo. No período clássico da Grécia Antiga, pode ser visto o uso do instituto. Pedro Batista Martins relata que um tratado firmado entre Esparta e Atenas, em 445 a.C já previa cláusula compromissória. Na Roma antiga, por sua vez, o uso da arbitragem se tornou muito comum com a invasão dos povos bárbaros. Os cidadãos romanos, desejosos de fugir à aplicação compulsória do direito invasor, firmavam compromisso no sentido de resolver a querela com base no direito livremente escolhido por eles, qual seja, o romano. Já no século XI, com a expansão da atividade negocial, diversos comerciantes lançaram mão da arbitragem para fugir da pluralidade de ordenamentos, aplicando a lex mercatoria aos conflitos. Após passar por um esfriamento nos séculos seguintes, o interesse é retomado no séc. XVIII, também pelo aumento da atividade negocial entre os indivíduos. Contudo, no séc. XIX o instituto sofre uma queda no seu uso, principalmente por conta da processualização conferida à si pelas reformas napoleônicas. Posteriormente, com a elaboração de diversos tratados sobre a matéria, diante da intensa globalização e necessidade de celeridade das decisões por conta da atividade comercial global, no séc. XX o interesse por esta $A D R$ cresce exponencialmente, chegando ao séc. hodierno com grande impacto. (Ibidem, pp36-37).

${ }^{188}$ Segundo Dolinger e Tiburcio, mister não confundir-se a arbitragem afeita ao direito internacional privado, com a de internacional público. Segundo os autores, a primeira trata de questões afeitas àquela matéria, tais como conflitos de território ou ligadas à órgãos multilaterais, tais como a Organização Mundial do Comércio, sendo arbitragens instituídas por tratados 
principalmente no tocante à questões envolvendo Estados soberanos. ${ }^{189}$ Vale notar que bem antes da promulgação da LArb, o instituto já estava presente no ordenamento jurídico pátrio.

Em sede constitucional, a Constituição do Império de 1824 tratou da arbitragem em seu art. $160^{190}$. O texto de 1895 , a primeira Constituição republicana, por sua vez foi omisso sobre a arbitragem. Já na Carta de 1934, por força de seu art. $5^{\circ}$, alínea c, coube ao instituto figurar dentre o rol de matérias cuja competência privativa para legislar compete à União. Por outro lado, os textos de 1937, 1946 e 1967 foram totalmente omissos quanto ao uso da arbitragem, o que não ocorreu com a vigente Lei Maior de 1988, embora trate do instituto timidamente em seu art. 114, §1 ${ }^{\circ}$. Já em matéria infraconstitucional, a arbitragem foi primeiramente regulada pelo Dec. 737/1850 e no Código Comercial do mesmo ano, nas relações negociais entre comerciantes. ${ }^{191}$ Naquele diploma, a arbitragem primeiramente foi dita obrigatória, disposição esta posteriormente revogada pela Lei n. 1.350/1866. Por conseguinte, o Código de Processo Civil de 1939 tratou do instituto, tendo o seu regramento totalmente reproduzido no Código de 1973, que dedicava todo o seu Capítulo XVI (artigos 1.072 a 1.102) à arbitragem. Contudo, com a edição da Lei 9.307/1996, a LArb, tais dispositivos foram revogados.

internacionais. Já a segunda, foco de nosso estudo, cuida de conflitos particulares, entre pessoas de direito privado. (DOLINGER, Jacob e TUBÚRCIO, Carmen, Op. Cit., pp19-20.)

${ }^{189}$ Valemo-nos novamente da lição de Batista Martins, que demonstra o uso da arbitragem em diversas questões. Nos exemplos trazidos pelo autor figuram: controvérsias territoriais com Argentina (1900), Guiana Britânica (1904) e Bolívia (1909) com relação ao Estado do Acre; questões patrimoniais envolvendo o naufrágio de uma embarcação norte-americana, em arbitragem com os EUA (1870), com Suécia e Noruega (1872) por acidente com uma embarcação norueguesa. (Ibidem, pp40-41).

${ }^{190}$ Art. 160. "Nas cíveis e nas penais civilmente intentadas, poderão as partes nomear juízes árbitros. Suas sentenças serão executadas sem recurso, se assim o convencionarem as partes.

${ }^{191}$ Ensina Pedro Batista Martins: “... o Código Comercial traz em seu bojo a figura do juízo arbitral e seguindo a tendência já delineada no passado, prescreve-o de modo obrigatório às questões (i) resultantes de contratos de locação mercantil, (ii) suscitadas pelos sócios, entre si, ou com relação à sociedade, inclusive quanto à liquidação ou partilha, (iii) de direito marítimo, no que toca a pagamento de salvados sobre avarias, repartição ou rateio das avarias grossas e (iv) relacionadas à quebra" (MARTINS, Pedro A. Batista, Op. Cit., p43). 
Contudo, por muito tempo observou-se a presença de diversos obstáculos à implementação concreta da mesma em nosso país. Tais obstáculos foram construídos tanto por produção legislativa, quanto por doutrina e jurisprudência pátrias. Não obstante estes obstáculos terem sido vencidos pelo advento da Lei 9.307/1996, como se verá a seguir, sempre esteve presente, outrossim, um elemento demasiadamente contrário na luta pela implementação da arbitragem em nosso país. Fazemos referência à forte intervenção do Estado no domínio privado (conforme anteriormente tratado no início deste trabalho), o que gerou um senso de "paternalismo" por parte da sociedade brasileira. Assim nos ensina Pedro Batista Martins:

\begin{abstract}
"A par dos obstáculos "visíveis", outros, de caráter psicológico ou cultural, também fizeram-se sentir contra a implementação da arbitragem, ressaltando-se a tendência nacional de se apegar ao Estado para a ele reportar todas as mazelas da sociedade, mesmo aquelas cuja solução não era da relevância do papel estatal. A estatização processou-se de tal forma no Brasil que o Estado avançou na jurisdição privada, tão forte e marcante, que as funções se diluíram no espaço, sucumbindo o particular a uma evidente e absoluta intervenção estatal. O indivíduo perde sua essência, capitula frente ao Estado, pai-de-todos. Não há que se falar em autonomia da vontade, porque o intervencionismo se faz em prol do social. (...) Diante desse cenário, não é de se estranhar que a arbitragem, calcada também na liberdade de contratar, não conseguisse ganhar campo no Brasil. O primado do Estado não suporta a justiça privada." 192
\end{abstract}

Vale notar, todavia, que treze anos passados desde a publicação da obra citada, observa-se uma paulatina superação desta cultura contrária à arbitragem. Pode-se citar, juntamente com o crescimento do número de casos nas câmaras arbitrais, a adoção do instituto pelo próprio Estado brasileiro para resolver conflitos patrimoniais, na esteira da grande mudança de paradigma ${ }^{193}$ na atuação do Estado, de provedor à regulador,

\footnotetext{
${ }^{192}$ Ibidem, p45.

${ }^{193}$ Neste sentido, ensina Di Pietro: "o que muda é principalmente a ideologia, é a forma de conceber o Estado e a Administração Pública. Não se quer mais o estado prestador de serviços; quer-se o Estado que estimula, que ajuda, que subsidia a iniciativa privada; quer-se a democratização da Administração Pública pela participação dos cidadãos nos órgãos de deliberação e de consulta pela colaboração entre público e privado na realização das atividades administrativas do Estado; quer-se a diminuição do tamanho do Estado para que a atuação da Administração Pública tenha maior eficiência." (DI PIETRO, Maria Sylvia Z., Parcerias na Administração Pública, São Paulo: Atlas, 2002, p16).
} 
com a subsequente adoção do modelo gerencial, esculpido no art. 37 da

CRFB. A adoção do instituto pelo próprio poder público é uma clara declaração da eficácia do mesmo como meio solucionador de conflitos.

\subsection{A Lei n. 9.307/1996}

A Lei brasileira teve sua origem na Lei Modelo da UNCITRAL (United Nations Comission on International Trade Law), conforme o texto de 1976, e as legislações francesa e espanhola sobre o tema. ${ }^{194}$ Segundo lição de Selma Lemes, a LArb veio sob os auspícios das “ondas renovatórias" no âmbito processual, caracterizadas pela primazia da efetiva prestação jurisdicional, dotada de celeridade e informalidade, quando possível. É neste contexto que surgem no direito pátrio os institutos da tutela antecipada, execução provisória e juizados especiais cíveis e criminais, bem como, no ano de 1996, a LArb. ${ }^{195}$

A importância da referida Lei para o instituto é gigantesca. Assim o é porque mesmo exercida antes do advento da LArb, ainda que de forma tímida e com diversos transtornos, conforme dito acima, é a promulgação da Lei Marco Maciel que confere a segurança jurídica tão preciosa a qualquer instituto, notadamente a arbitragem, tão afeita à realidade dos

\footnotetext{
${ }^{194}$ Segundo Selma Maria Ferreira Lemes, coautora da Lei 9.307/1996: “A Lei n. 9.307, de 23/9/96, que disciplina a arbitragem no Brasil, tem sua gênese na Lei Modelo da Uncitral (LM) (...). Esta comissão das Nações Unidas foi criada em 1966, tem sede em Viena e desde sua constituição, vem prestando inestimáveis serviços à comunidade jurídica internacional. Nesse sentido, através dos trabalhos de um Comitê formado por representantes de 58 países, incluindo o Brasil, e 18 organizações internacionais, durante três anos, discutiu os termos de uma lei-modelo sobre arbitragem, com o intuito de, em lugar de unificar a matéria através de uma convenção internacional, buscar a harmonização das diversas legislações internas. Esta é, indubitavelmente, a razão do sucesso da LM, cujo texto final foi aprovado pela Assembleia Geral das Nações Unidas através da Resolução 40/72, de 11/12/85. Hoje já se contam, às dezenas, os países que incorporam, às suas legislações internas, a LM, adotando-a in totum ou parcialmente, seja tratando somente de arbitragem internacional, seja aplicando-a também à arbitragem doméstica. (...) A regulamentação arbitral brasileira também teve fonte de inspiração na lei francesa de 1981 , ao estabelecer a convenção de arbitragem, que também está prevista no art. $7^{\circ}$ da LM (art. $3^{\circ}$ da LAB), bem como em muitos dispositivos da lei espanhola n. 36/1988, como por exemplo o art. 56.1, equivalente ao artigo 34 da LAB." (LEMES, Selma Ferreira, "Princípios e origens da Lei de Arbitragem" In: Revista do Advogado, n. 51, 1997, pp.34-35). Para a Lei Modelo da UNCITRAL, cf. http://www.uncitral.org/pdf/english/texts/arbitration/ml-arb/07-86998_Ebook.pdf.

${ }^{195}$ Idem, "O Desenvolvimento da Arbitragem no Brasil e no exterior". In: Revista Vasca de Derecho Procesal y Arbitraje, Universidad del Pais Vasco, 2005, tomo XVII, p394.
} 
negócios comerciais, que por sua vez preza a segurança e a previsibilidade das decisões para o florescimento de uma intensa atividade empresarial.

É inegável que a LArb trouxe consigo diversas mudanças à realidade arbitral brasileira. Contudo, duas delas se impõem com relevo. ${ }^{196}$ A primeira subsiste no fato da sentença arbitral (até então apenas laudo) ter agora a natureza jurídica de título executivo judicial, ${ }^{197}$ por força do art. 31 da Lei. ${ }^{198}$ Neste sentido, ensina Batista Martins:

\begin{abstract}
"por sinal, a teor da lei, equipara-se a sentença arbitral às decisões proferidas pelo Poder Judiciário. Quer isso dizer que as decisões emanadas de árbitros contemplam os mesmo conteúdos da sentença judicial, delas emanam os mesmos efeitos e a mesma qualidade (i.e., trânsito em julgado). (...) A sentença arbitral, portanto, em tudo se assemelha à sentença judicial. Não detém nem mais, nem menos força, força jurídica do que a sentença judicial. Elas se equiparam para todos os fins e efeitos de direito." $" 199$
\end{abstract}

Antes do advento da LArb, era necessário que o laudo arbitral fosse homologado em juízo para produzir efeitos entre as partes contratantes. Tal procedimento era totalmente ilógico e fazia a arbitragem perder dois de seus maiores trunfos: celeridade e confidencialidade. Passado o processo arbitral, caso o vencido não quisesse cumprir por espontânea vontade o laudo, deveria o vencedor entrar na demorada via judicial para ver o laudo gerar efeitos. Este exame era mero giudizio di delibazione, de caráter

\footnotetext{
${ }^{196}$ Dolinger e Tiburcio apontam que a distinção entre cláusula compromissória e compromisso, bem como a necessidade de homologação judicial do laudo consistiam nas duas características principais no tocante à arbitragem em nosso país. (DOLINGER, Jacob e TIBURCIO, Carmen, Op. Cit., p21).

${ }^{197}$ Ainda pesa uma certa divergência (totalmente injustificada, saliente-se) em alguns Tribunais sobre a natureza de título executivo judicial da sentença arbitral. Contudo, entendemos que tal fato ocorre pela desatualização dos mesmo em relação à legislação vigente, uma vez que a LArb consagrou o sentença como título judicial. Neste sentido, TJRJ, Agravo de Instrumento no. 11305/05, Rel. Des. Jorge Habib, em 06.09.05; TJSC, Conflito de Competência no. 2004.0040075, Re. Des. Orli Rodrigues, em 29.06.04. Já em sentido diverso, o TJSP em 2001, no caso Corduroy S.A vs. TCT United S.A, considerou a sentença arbitral como titulo extrajudicial, no Agravo de Instrumento n. 187.195-4/9-00, Rel. Des. Zélia Maria Alves, em 21.05.01, assim como o TJRS, na Apelação Cível 70005976881, Re. Des. Heemann Junior, em 01.04.04.

${ }^{198}$ Art. 31. A sentença arbitral produz, entre as partes e seus sucessores, os mesmos efeitos da sentença proferida pelos órgãos do Poder Judiciário e, sendo condenatória, constitui título executivo.

${ }^{199}$ MARTINS, Pedro A. Batista, Apontamentos sobre a Lei de Arbitragem: comentários à Lei 9.307/1996”. Rio de Janeiro: Forense, 2008, p307.
} 
administrativo, não enfrentando questões de fundo, restringindo-se tão somente às formalidades necessárias à validade do laudo ${ }^{200}$. Esta via crucis era ainda maior na hipótese de decisões estrangeiras, que necessitavam da vil dupla homologação, ${ }^{201}$ superada pelo art. 35 da LArb $^{202}$, que prevê uma única homologação.

Outra contribuição valorosa da LArb que superou grande obstáculo na prática arbitral brasileira é a reunião do compromisso e da cláusula compromissória como espécies do gênero convenção arbitral, por força de seu art. $3^{0203}$, conferindo a possibilidade de execução específica da cláusula

\footnotetext{
${ }^{200}$ Idem, Op. Cit., p51. Neste sentido, a Segunda Turma do STF, no julgamento do RE 86263/RJ, em acórdão relatado pelo Min. Leitão de Abreu, proferiu o seguinte voto, apoiando-se em Almicar de Castro: "Para a homologação do laudo arbitral o juiz não entra, em regra, no fundo da questão julgada pelos árbitros, ou na apreciação do mérito do laudo, a não ser, por exceção, no caso do art. 1.100 do Código de Processo, combinado com o art. 1.102, o juiz ou tribunal, diz Amilcar de Castro, ao tomar conhecimento da sentença para 'mandar executá-la, toca de leva apenas em seus requisitos, examinando a sua legitimidade, sem entrar no fundo da questão, ou no mérito do julgado"” (STF, $2^{\mathrm{a}}$ Turma, RE 86263/RJ Rel. Min. Leitão de Abreu, data de julgamento: 19/09/1980). Assim também a Primeira Turma da Suprema Corte, em 1956: "Em se tratando de juízo arbitral, ou o juiz homologa o laudo, ou não homologa, no caso de infringência a disposição de lei. Ao juiz homologador não é dado apreciar questão de fato. (STF, $1^{\text {a }}$ Turma, voto do Min. Sampaio Costa no RE 32226, data de julgamento: 16/08/1956).

${ }^{201}$ É como ensina Arnoldo Wald: "A sentença arbitral proferida em território nacional tem autoridade de coisa julgada material, produzindo os mesmos efeitos de um título executivo. Por isso, pode ser executada imediatamente, ao contrário do que acontecia antes, quando a legislação exigia a homologação judicial da decisão arbitral, fosse ela interna ou estrangeira, sendo necessária, para esta última uma dupla homologação (no país de origem e, em seguida, no Brasil, pelo STF)." (WALD, Arnoldo, "Novos rumos para a arbitragem no Brasil", Revista de Direito Bancário, do Mercado de Capitais e da Arbitragem. São Paulo: Revista dos Tribunais, no. 14, out./dez., 2001, p349)

${ }^{202}$ Art. 35. Para ser reconhecida ou executada no Brasil, a sentença arbitral estrangeira está sujeita, unicamente, à homologação do Supremo Tribunal Federal". Comentando este dispositivo, aduz Pedro Batista Martins: "Além de injusto o chamado duplo exequatur, a homologação pelo juiz local é procedimento totalmente desnecessário e burocrático que merecia ser revisto. Ainda mais nos dias de hoje quando a própria Constituição Federal estabelece em seu art. $5^{\circ}$, inciso LXXVIII, que 'a todos, no âmbito judicial e administrativo, são assegurados a razoável duração do processo e os meios que garantam a celeridade de sua tramitação"'. (MARTINS, Pedro A. Batista, Op. Cit., p368).

${ }^{203}$ Art. $3^{\circ}$. As partes interessadas podem submeter a solução de seus litígios ao juízo arbitral mediante convenção de arbitragem, assim entendida a cláusula compromissória e o compromisso arbitral. A jurisprudência anterior era no sentido contrário. Como se depreende no REsp no. 616RJ, datado de 13.08.1990, conforme o voto do relator original (vencido) Min. Cláudio Santos: "daí não se equiparar a cláusula compromissória ao compromisso, previsto no art. 1.073 do $\mathrm{CPC}$, tanto mais que são institutos diversos." Contudo, vale notar que em voto-vista que sagrou-se vencedor, o Min. Gueiros Leite, apoiando-se no Protocolo de Genebra, defendeu a não distinção entre os dois institutos em arbitragens internacionais. (STJ, REsp no. 616-RJ, $3^{\mathrm{a}}$ Turma, Rel. Min. Gueiros Leite, data de julgamento: 13.08.1990).
} 
compromissória $\left(\right.$ art. $\left.7^{\circ}\right),{ }^{204}$ que até então era entendida apenas como

passível de conversão em perdas e danos diante de seu não cumprimento ${ }^{205}$, em consonância com a já consagrada doutrina internacional. ${ }^{206}$

${ }^{204}$ Art. $7^{\text {o }}$. Existindo cláusula compromissória e havendo resistência quanto à instituição da arbitragem, poderá a parte interessada requerer a citação da outra parte para comparecer em juízo a fim de lavrar-se o compromisso, designando o juiz audiência especial para tal fim.

${ }^{205}$ Esta posição foi sintetizada pelo Supremo Tribunal Federal em 1967, no julgamento do RE 58.696-SP. Desde então, tal acórdão ditou os rumos na discussão da matéria na jurisprudência pátria até o advento da LArb, sendo citado por diversos outros Tribunais. Assim consta na ementa do referido acórdão: "Cláusula compromissória (pactum de comprometendo) ainda não é compromisso constitutivo de juízo arbitral, mas obrigação de o celebrar. Trata-se de uma obrigação de fazer, que se resolve em perdas e danos e que, como pacto de ordem privada, não torna incompetente o juiz natural das partes, se a ele recorrerem." (STF, RE 58.696-SP, Terceira Turma, Rel. Min. Luiz Gallotti, dj. 02.06.1967). Décadas mais tarde, a Min. Ellen Gracie, em voto no célebre caso em que o STF se debruçou sobre a constitucionalidade da LArb aduz o seguinte: “Ao instituir a execução específica da cláusula compromissória, a Lei no. 9.307/96 afastou o obstáculo que, até então, tornava praticamente inexistente a arbitragem em nosso país. Toda vez que se quisesse furtar a uma solução célere da controvérsia - ou mesmo, ao simples reconhecimento de sua responsabilidade pela quebra do contrato - à parte inadimplente bastava recusar-se a firmar o compromisso arbitral. Ao juízo era vedado substituir-se a esta sua manifestação - ainda que a controvérsia, perfeitamente delimitada, decorresse exatamente do desenvolvimento natural do contrato e versasse sobre direitos de natureza disponível. (...) Negar possibilidade que a cláusula compromissória tenha plena validade e que enseje execução específica importa em erigir em privilégio da parte inadimplente o furtar-se à submissão à via expedita de solução da controvérsia, mecanismo este pelo qual optara livremente, quando da lavratura do contrato original em que inserida essa previsão. É dar ao recalcitrante o poder de anular condição que - dada a natureza dos interesses envolvidos - poder ter sido consideração básica à formação da avença. É inegável que, no mundo acelerado em que vivemos, ter, ou não, acesso a fórmulas rápidas de solução das pendências resultantes do fluxo comercial, constitui diferencial significativo no poder de barganha dos contratantes.” (STF, Ag. Reg. na SE 5.2067/Espanha, Tribunal Pleno, Rel. Min. Sepúlveda Pertence, dj.12/12/2001). Esta posição, conforme ensina Pedro Batista Martins foi defendida por grandes nomes do direito pátrio, que entendiam a cláusula compromissória como mero pacto de contrahendo, tais como Waldemar Ferreira, Alfredo Bernandes e Eduardo Espínola. (MARTINS, Pedro A. Batista, Op. Cit., p47). Selma Lemes explica a alteração trazida pela LArb: "Observamos que a cláusula compromissória não representa obrigação de comprometer, posto que comprometidas estão as partes desde o momento que firmaram o contrato e dispuseram sobre a solução de controvérsias por arbitragem (efeito vinculante da cláusula compromissória). A obrigação vindoura é a de instituir a arbitragem no momento do conflito; daí, portanto, o que se espera com a referida ação é a 'concretização' pelo juiz do direito do credor em instituir a arbitragem (...)" (LEMES, Selma M. Ferreira, "Cláusulas Arbitrais ambíguas ou contraditórias e a interpretação da vontade das partes", In: Reflexões sobre Arbitragem, in memoriam do Desembargador Cláudio Vianna de Lima”, MARTINS, Pedro A. Batista e GARCEZ, José Maria Rossani (coord.), São Paulo: LTr, 2002, pp170-171). Pode-se observar este procedimento nos tribunais pátrios nestes seguintes acórdãos: TJSP, 6 a Câmara de Direito Privado, Agravo de Instrumento n. 197.978-4/0, Rel. Des. Reis Kuntz, dj. 09.05.01; STF, Tribunal Pleno, SEC n. 5.847-1/Reino Unido, Rel. Min. Maurício Corrêa, dj. 01.12.99; TJSP, 9 ${ }^{\mathrm{a}}$ Câmara de Direito Privado, Agravo de Instrumento n. 257.416..4/3, Rel. Des. Alberto Tedesco, dj. 24.09.2002; e TJRJ, $13^{\mathrm{a}}$ Câmara Cível, Apelação n. 28.020/2002, Rel. Des. Ademir Pimentel, dj. 27.08.2003).

${ }^{206}$ Segundo a lição clássica de Fouchard, Gailliard e Goldman: "It is now firmly established that parties are obliged to submit disputes covered by an arbitration agreement to arbitration (A) and that this obligation is capable of specific performance. (B)" (em tradução livre: "Já está solidamente firmado que as partes estão obrigadas à submeter conflitos cobertos por uma cláusula compromissória à arbitragem, e que esta cláusula é passível de execução específica" 
Finalmente, o Supremo Tribunal Federal, quando do julgamento da SE 5.206-7, ${ }^{207}$ proveniente da Espanha, debruçou-se extensamente sobre a constitucionalidade da Lei Brasileira, decidindo favoravelmente à mesma, aduzindo que a execução específica da cláusula compromissória, espécie de convenção de arbitragem que é, não viola o direito fundamental de acesso à justiça, contida no art. $5^{\circ}, \mathrm{XXXV}$ da CRFB. ${ }^{208}$

\subsection{Natureza Jurídica da Arbitragem}

Conforme dito anteriormente, a arbitragem representa o que há de mais arrojado na discussão sobre a autonomia da vontade. Por conseguinte, sendo a arbitragem um instituto de solução de conflitos autônomo e independente da jurisdição estatal, estaria a arbitragem sujeita a algum direito interno, ou ao direito internacional, ou a ambos, ou ainda, a nenhum

(FOUCHARD, Phillipe; GAILLARD, Emmanuel; GOLDMAN, Bertold. Fouchard Gaillard Goldman on international arbitration, Haia: Kluwer Law International, 1999, p381, §626).

${ }^{207}$ A ementa, no que toca nossa discussão traz o seguinte: “3. Lei de Arbitragem (L. 9.307/96): constitucionalidade, em tese, do juízo arbitral; discussão incidental da constitucionalidade de vários dos tópicos da nova lei, especialmente acerca da compatibilidade, ou não, entre a execução judicial específica para a solução de futuros conflitos da cláusula compromissória e a garantia constitucional da universalidade da jurisdição do Poder Judiciário (CF, art. $5^{\circ}$, XXXV). Constitucionalidade declarada pelo plenário, considerando o Tribunal, por maioria de votos, que a manifestação de vontade da parte na cláusula compromissória, quando da celebração do contrato, e a permissão legal dada ao juiz para que substitua a vontade da parte recalcitrante em firmar o compromisso não ofenda o artigo $5^{\circ}, \mathrm{XXXV}$, da CF." O emblemático caso foi decidido por maioria de votos, tendo sido o relator, Min. Sepúlveda Pertence, defendido a inconstitucionalidade do art. $7^{\circ}$ da LArb. Acompanharam seu pensamento - vencido - os Ministros Sydney Sanches, Néri da Silveira e Moreira Alves. Favoráveis à constitucionalidade votaram os Ministros Nelson Jobim, Ilmar Galvão, Ellen Gracie, Maurício Corrêa, Marco Aurélio e Celso de Mello.

${ }^{208}$ Trazemos trecho extremamente didático do voto exarado pela Min. Ellen Gracie no caso: "A leitura que faço da garantia enfocada no art. $5^{\circ}, \mathrm{XXXV}$, é de que a inserção da cláusula assecuratória de acesso ao judiciário, em nosso ordenamento constitucional, tem origem e se explica pela necessidade de precatarem-se os direitos dos cidadãos contra a atuação de órgãos administrativos, próprios de regimes autoritários. A arqueologia da garantia da via judiciária levanos a verificar que a cláusula sempre teve em mira, preponderantemente, o direito de defesa ante os tribunais, contra atos dos poderes públicos. Por isso mesmo é, ineludivelmente, o legislador o destinatário da norma que reza: "a lei não excluirá da apreciação do Poder Judiciário lesão ou ameaça a direito". (...) Entendo que a garantia de acesso ao judiciário é daqueles direitos fundamentais nos quais se reconhece maior peso ao que Canotilho (...) denomina de função de direitos de defesa dos cidadãos. Ou seja, no plano jurídico-objetivo, representa a impossibilidade, para o Estado-legislador, de excluir da apreciação judicial determinadas matérias e, no plano jurídico-subjetivo, "o poder de exercer positivamente o direito de ação". (...) Como se vê, o cidadão pode invocar o judiciário, para a solução de conflitos, mas, mas não está proibido de valer-se de outros mecanismos de composição de litígios. Já o Estado, este sim, não pode afastar do controle jurisdicional as divergências que a ele queiram submeter os cidadãos." (grifos no original) Para uma abordagem percuciente sobre a constitucionalidade da LArb, bem como a síntese de todos os votos no julgamento da SE 5.206-7, cf. DOLINGER, Jacob e TIBURCIO, Carmen, Op. Cit., pp49-69. 
deles, sendo sujeito exclusivamente às suas próprias regras? A doutrina aponta a resposta à esta questão reportando à natureza jurídica ${ }^{209} \mathrm{da}$ arbitragem.

Segundo a lição clássica de Fouchard, Gaillard e Goldman, há dois elementos constitutivos do instituto da arbitragem, reconhecidos unanimemente tanto pela doutrina quanto jurisprudência das cortes nos mais diferentes países. São estes: o caráter judicial e a fonte contratual do instituto.

\begin{abstract}
"In our view, arbitration should be defined by reference to two constituent elements which commentators and the courts almost unanimously recognize. First, the arbitrators' task is to resolve a dispute. Second, the source of this judicial role is a contract: the arbitrators' power to decide a dispute originates in the common intention of the parties. Thus, arbitration compromises both a judicial and a contractual element.",210
\end{abstract}

Diante destes dois elementos precípuos, quais sejam, o jurisdicional e o contratual, há quatro diferentes teorias acerca da natureza jurídica da arbitragem, discussão esta que gera grandes discussões entre a academia. São estas, i) teoria jurisdicional; ii) teoria contratual; iii) teoria mista (entre as duas anteriores); e ainda iv) teoria autônoma, apenas no contexto de arbitragens internacionais.

De acordo com a teoria jurisdicional, a jurisdição não é um monopólio do Estado, ${ }^{211}$ uma vez que este mesmo possibilita que um

\footnotetext{
209 "Determinar a natureza jurídica de uma instituição, regra ou relação entre duas pessoas é determinar-lhe o lugar no sistema do Direito" (PASQUIER, Claude du. Apud CRETELLA NETO, José, Curso de Arbitragem: arbitragem comercial, arbitragem internacional, lei brasileira de arbitragem, direito privado brasileiro aplicado à arbitragem, convenções internas". Rio de Janeiro: Forense, 2004, p13).

${ }^{210}$ Numa tradução livre: "Para nós, a arbitragem deve ser definida em referência a dois elementos constitutivos que comentaristas e cortes quase unanimemente reconhecem. Primeiro, a tarefa dos árbitros é resolver um conflito. Segundo, a fonte deste papel judicial é o contrato: o poder do árbitro para decidir um conflito origina-se da vontade mútua das partes. Destarte, a arbitragem compreende tanto um elemento judicial quanto contratual." (FOUCHARD, Phillipe; GAILLARD, Emmanuel; GOLDMAN, Bertold. Op. Cit., p11, §11).

${ }^{211} \mathrm{O}$ processualista Leonardo Greco traz valiosa lição e pensamento vanguardista sobre a desestatização da jurisdição. Segundo o doutrinador, "no nosso tempo, no estágio de desenvolvimento das relações Estado-cidadão a que os europeus chegaram após a Segunda Guerra e a que nós chegamos com a Constituição de 1988, muitos entendem que a jurisdição não precisa
} 
terceiro atue na resolução de um conflito de interesses, como se Estado fosse. ${ }^{212}$ Destarte, os defensores desta teoria apoiam-se, no contexto brasileiro, nos arts. 18 e 31 da LArb, ao dispor que o árbitro deve ser considerado juiz de fato e de direito na resolução do conflito, e que sua decisão não necessita ser homologada para gerar efeitos inter partes, tendo a qualidade de título executivo judicial. Estes teóricos não tergiversam a realidade de ser a arbitragem fundada na vontade das partes, mas aduzem que essa possibilidade tem como base a lei. Entre os chamados publicistas figuram Carlos Alberto Carmona, ${ }^{213}$ Carreira Alvim, ${ }^{214}$ Pedro Batista Martins, ${ }^{215}$ Fredie Didier Jr., ${ }^{216}$ Jacob Dolinger e Carmen Tiburcio, ${ }^{217}$ estes últimos afirmando que esta é a corrente mais adotada no contexto brasileiro.

ser necessariamente uma função estatal, porque a composição de litígios e a tutela de interesses particulares podem ser exercidas por outros meios, por outros órgãos, e até por sujeitos privados, seja através da arbitragem, seja através da justiça interna das associações. (...) Na maioria dos países, contudo, ainda que tenham sido implementados mecanismos não estatais de solução de conflitos, como, entre nós, a arbitragem, através da Lei n. 9.307/96, eles não receberam a totalidade dos poderes que caracterizam a jurisdição. Portanto, nesses países, neles incluído o Brasil, ainda a jurisdição é uma função tipicamente estatal. Daí dizer-se que o conceito de jurisdição é um conceito em evolução, na medida em que alguns sistemas jurídicos conseguiram desprendê-lo do Estado, pelo menos em parte, e outros ainda o associam a uma função essencialmente estatal. Será que a História vai confirmar a evolução no sentido da desestatização da jurisdição? Eu pessoalmente acredito que sim (...) não se pode desligar totalmente o conceito de jurisdição de uma função tipicamente estatal, ou preponderantemente estatal, porque, entre nós, ela ainda o é, embora essa não me pareça a sua característica essencial. É uma característica histórica da jurisdição, que tem mil e setecentos anos, aproximadamente, mas que já apresenta sinais de desgaste, que poderão levar, num prazo que ainda não pode ser previsto, a uma superação dessa vinculação. (GRECO, Leonardo. "Instituições de processo civil", volume I. Rio de Janeiro: Forense, $3^{\mathrm{a}}$ ed., 2011, pp55-56).

${ }^{212}$ DOLINGER, Jacob e TIBURCIO, Carmen. Op. Cit., p94.

213 “O art. 32 (da Lei 9.307/96) afirma que a decisão final dos árbitros produzirá os mesmos efeitos da sentença estatal, constituindo a sentença condenatória título executivo que, embora não oriundo do Poder Judiciário, assume a categoria de judicial. O legislador optou, assim, por adotar a tese jurisdicional da arbitragem (...). certamente continuarão a surgir críticas, especialmente de processualistas ortodoxos que não conseguem ver a atividade processual - e muito menos jurisdicional - fora do âmbito da tutela estatal estrita." (CARMONA, Carlos Alberto, "Arbitragem e Processo - Um comentário à Lei n. 9.307/96”. São Paulo: Atlas, 2a ed., 2004, p45). O doutrinador, em análise arguta sobre a matéria da jurisdição, indica que ela está presente na pessoa do árbitro, de forma ad hoc, tendo sua natalidade e óbito de acordo com o início e fim da arbitragem.

214 “Quando se afirma a base convencional da arbitragem, não se define a sua natureza jurídica, senão identifica-se a forma por que ela se constitui. Por idêntica razão, ninguém diria que o Tribunal do Júri tem natureza jurídica aleatória pelo simples fato de serem os jurados escolhidos por sorteio" (ALVIM, J. E. Carreira, "Tratado Geral da Arbitragem". Belo Horizonte: Mandamentos, 2000, p133).

${ }^{215}$ MARTINS, Pedro A. Batista, Op. Cit., In: GARCEZ, José Maria Rossani (Coord.), Op. Cit., pp38-39.

216 “(...) a arbitragem, no Brasil, não é equivalente jurisdicional: é propriamente jurisdição, exercida por particulares, com autorização do Estado e como consequência do exercício 
Já os adeptos da teoria contratualista aduzem que a arbitragem, por ter na autonomia da vontade sua base, uma vez que às partes cabe a escolha de instituírem ou não a arbitragem, se esta será institucional ou ad hoc, quem serão os árbitros, qual a sede, lei aplicável e procedimento a ser seguido, encontra sua natureza jurídica no contrato. Como ensina José Cretella Neto, para os defensores desta teoria a arbitragem consiste em obrigação criada por contrato. ${ }^{218}$ Ademais, argumentam que a jurisdição é manifestação da soberania, e por conseguinte, monopólio estatal. Entre os privatistas, Sérgio Bermudes, ${ }^{219}$ Alexandre Freitas Câmara, Luiz Guilherme Marinoni ${ }^{220}$, Daniel Mitidiero, ${ }^{221}$ dentre outros de linha processual.

Buscando um ponto médio entre as duas posições e reconhecendo nelas elementos presentes na arbitragem, buscou-se uma teoria mista, uma vez que vê-se claramente a natureza convencional, por conta de sua origem ser a convenção de arbitragem, da mesma forma que vê-se a natureza jurisdicional, uma vez que sua função é a elaboração do laudo, portanto, diz $o$ direito. Entres seus defensores figuram José Cretella Neto, ${ }^{222}$ Irineu

fundamental de auto-regramento (autonomia privada). (DIDIER JR., Fredie, "Curso de Direito Processual Civil", volume I. Salvador: JusPodivm, $11^{\mathrm{a}}$ ed., 2009, p82).

${ }^{217}$ Falando sobre o status de título executivo judicial dado pela LArb à sentença arbitral, posicionam-se os autores: "essa inovação está em consonância com a natureza jurisdicional conferida à arbitragem pela Lei n. 9.307, ao equiparar o laudo arbitral à sentença judicial." (DOLINGER, Jacob e TIBURCIO, Carmen, Op. Cit., p36).

${ }^{218}$ CRETELLA NETO, José. Op. Cit., p14. Curioso é o fato que o doutrinador afirma categoricamente que a corrente publicista já se encontra superada entre nós, o que parece ser incorreto diante da evidência doutrinária.

${ }^{219}$ BERMUDES, Sérgio, "Introdução ao Processo Civil". Rio de Janeiro: Forense, $4^{\mathrm{a}}$ ed., 2006, pp19-29.

${ }^{220}$ Segundo o processualista, a natureza é contratual por ser a arbitragem fundada na autonomia da vontade, configurando uma renúncia à jurisdição. Aduz ainda que a falta da coercio e executio por parte do árbitro configura não-jurisdição. (MARINONI, Luiz Guilherme, "Teoria Geral do Processo", volume I. São Paulo: RT, 2006, pp147-148). Contudo, insta salientar que a falta de coercibilidade na atuação do árbitro é uma questão de incompetência, e não de jurisdição.

${ }^{221}$ MITIDIERO, Daniel Francisco. "Elementos para uma teoria contemporânea do processo civil brasileiro". Porto Alegre: Livraria do Advogado, 2005, p88.

${ }^{222}$ Ao citar a posição mista de José Carlos de Magalhães, conclui: "entendemos, como esse autor, que a arbitragem tem natureza jurídica mista, sui generis." (CRETELLA NETO, José. Op. Cit., p15). 
Strenger, Alexandre Freitas Câmara, ${ }^{223}$ José Carlos de Magalhães, ${ }^{224}$ dentre outros.

\subsection{Importantes convenções ratificadas pelo Brasil}

Nos últimos anos, a República ratificou alguns diplomas convencionais de relevo no tocante à arbitragem. Vencendo um grande lapso temporal, finalmente a Convenção sobre o Reconhecimento e a Execução de Sentenças Arbitrais Estrangeiras (Convenção de Nova York), datada de 1958, foi promulgada em nosso país por força do Dec. $4.311 / 2002,{ }^{225}$ que revogou expressamente o antigo Protocolo de Genebra, datado de 1923.

No âmbito do MERCOSUL tem-se a ratificação, no fim do ano de 1996, do Protocolo de Cooperação e Assistência Jurisdicional em Matéria

\footnotetext{
223 "Parece-me que as duas posições são criticáveis. Em primeiro lugar, deve-se afirmar, a meu juízo, a função exercida pelos árbitros é pública, por ser função de pacificação de conflitos, de nítido caráter de colaboração com o Estado na busca de seus objetivos essenciais. De outro lado, parece inegável que a arbitragem, se inicia por ato de direito privado, qual seja, a convenção de arbitragem (...). Não se pode, porém, confundir a convenção de arbitragem com a arbitragem em si. É a natureza desta, e não daquela, que se busca, e tal natureza é, a meu juízo, a de função pública. Pública, mas não estatal, e - por conseguinte - não se poderia considerar que tal função é jurisdicional. Pensar de outra forma, a meu ver, seria infringir o monopólio estatal da jurisdição, o que não me parece possível. Relembre-se agora o que já disse anteriormente: o Estado não possui o monopólio da Justiça, mas possui o da Jurisdição. (...) Sendo a arbitragem um procedimento que se realiza obrigatoriamente em contraditório (o que, aliás, é determinado de forma cogente pela lei de arbitragem, que impõe a observância de tal princípio no procedimento arbitral), faz-se presente o 'módulo processual', devendo-se considerar, pois, que a arbitragem é um processo. Não, porém, um processo jurisdicional, pois a jurisdição é monopólio do Estado, não podendo ser exercida pelo árbitro, o qual é um ente privado. Ademais, não se faz presente na arbitragem a relação jurídica processual jurisdicional, qual seja, aquela que se estabelece entre as partes e o Estado-Juiz. Não há, portanto, como se admitir a natureza jurisdicional da arbitragem, embora não se possa negar o múnus público exercido pelo árbitro, em sua atividade provada, de busca da pacificação social. Com isto, coloco-me numa posição publicista frente à arbitragem, negando a tese de quem vê neste instituto uma figura exclusivamente regulada pelo direito privado." (CÂMARA, Alexandre Freitas, "Arbitragem". Rio de Janeiro: Lumen Juris, $4^{\mathrm{a}}$ ed., 2005, pp12-15).

224 "Se a arbitragem é contratual em seu fundamento (o compromisso) é, também jurisdicional, ante a natureza pública do laudo arbitral, como forma privada de solução de litígios". MAGALHÃES, José Carlos de., Apud CRETELLA NETO, José. Op. Cit., p15.

${ }^{225}$ A Convenção de Nova York tem importante papel conferido pela LArb, uma vez que o art. 34 da $r$. lei prevê que a sentença estrangeira a ser executada ou homologada deverá observar "os tratados internacionais" com eficácia em nosso ordenamento, incidindo diretamente os termos da LArb sobre a matéria apenas na ausência de convenção. Destarte, pode ser apontado como o maior benefício proveniente da ratificação da Convenção de NY o fato desta ser um diploma adotado por 133 países, o que nas palavras de Dolinger e Tiburcio, gera um "direito uniformizado em matéria de reconhecimento e execução de laudos arbitrais estrangeiros", conferindo uma clara segurança jurídica. (DOLINGER, Jacob e TIBURCIO, Carmen. Op. Cit., p43).
} 
Civil, Comercial, Trabalhista e Administrativa (Las Leñas) datada de 1992, e promulgada entre nós pelo Dec. 2.067/1996. Ademais, tem-se no ano de 2001 a aprovação do Acordo sobre Arbitragem Comercial entre Mercosul, Bolívia e Chile de 1998, por força do Dec. Leg. 483/2001 (ainda aguardando promulgação), bem como do Acordo sobre Arbitragem Comercial Internacional do Mercosul, datado também de 1998, por força do Dec. 4.719/2003.

Estas recentes normas de direito convencional vem somar às convenções anteriormente adotadas pela República do Brasil, tais como a Convenção do Panamá de 1975 (Convenção Interamericana sobre Arbitragem Comercial Internacional), bem como a Convenção de Montevidéu de 1979. Dentre os importantes diplomas convencionais que o Brasil ainda não retificou, faz-se referência à Convenção de Washington de 1966, acerca do ICSID (Internacional Centre for Settlement of Investment Disputes), cujo objeto é a arbitragem em conflitos advindos de investimentos, tendo sido ratificada por diversos países. ${ }^{226}$

\footnotetext{
${ }^{226}$ Para o texto desta e de diversas outras Convenções que tratam de arbitragem, cf. DOLINGER, Jacob e TIBURCIO, Carmen, Op. Cit., parte V.
} 


\section{Código Civil, Autonomia e Arbitragem: entre liberdade e responsabilidade}

O Código Civil de 2002 encontra-se sob as diretrizes axiológicas de eticidade e socialidade. ${ }^{227}$ Tais diretrizes afetam todo o regramento legal obrigacional, impondo aos negócios jurídicos o agir pautado na consideração pelo alter, ${ }^{228}$ com a legítima expectativa de regularidade deste agir por parte de qualquer convenente, como corolário da boa-fé objetiva, que exerce limitações aos direitos subjetivos inerentes ao exercício da autonomia. Sendo a convenção de arbitragem, espécie do gênero negócio jurídico, à ela também se impõem a eticidade e socialidade.

Destarte, no campo da eticidade, uma série de situações podem ser elencadas no sentido de mostrar como o instituto da arbitragem pode ser beneficiado pela tábua axiológica do CC2002, no que tange à proteção da convenção de arbitragem.

\subsection{Autonomia em arbitragem e venire contra factum proprium}

Em primeiro lugar, fazemos referência ao princípio da proibição do comportamento contraditório, o chamado venire contra factum proprium, cujo fundamento encontra-se na boa-fé objetiva contida no art. 422 e a tutela contra o ato ilícito prevista no art. 187 , ambos do Código Civil. ${ }^{229}$ Segundo a produção doutrinária na V Jornada de Direito Civil, o princípio da boa-fé objetiva torna-se concreto, entre outras hipóteses, também através da proibição ao comportamento contraditório, pelo teor do novel enunciado 412:

\footnotetext{
227 "Se por um lado a socialidade estabelece como parâmetro de interpretação do código e da realização de negócios jurídicos um profundo caráter solidário, ou seja, um agir em consideração da coletividade, a eticidade prima por manifestar no plano civil a opção constitucional de elevar a princípio fundamental a dignidade da pessoa humana." (SILVA, Eduardo Silva da. Op. Cit. p64)

${ }^{228}$ PINTO, José Emílio Nunes. "A Cláusula compromissória à luz do Código Civil”. In: Revista de Arbitragem e Mediação, WALD, Arnoldo (Coord.), 2005, volume 4, p35.

${ }^{229}$ AZEVEDO, Fábio de Oliveira. Op. Cit., p101.
} 
Enunciado 412. Art. 187. As diversas hipóteses de exercício inadmissível de uma situação jurídica subjetiva, tais como supressio, tu quoque, surrectio e venire contra factum proprium, são concreções da boa-fé objetiva.

Ademais, Anderson Schreiber, em obra sobre este princípio implícito $^{230}$ no CC2002, aduz que:

“(...) mais que contra a simples incoerência, atenta o venire contra factum proprium à confiança despertada na outra parte, ou em terceiros, de que o sentido objetivo daquele comportamento inicial seria mantido, e não contrariado."231

Com efeito, o princípio da proibição do comportamento contraditório visa salvaguardar a legítima confiança no trato inter partes, confiança esta tão cara ao instituto da arbitragem. Neste sentido, viola a eticidade ínsita ao CC2002 o contratante que, tendo convencionado de livre vontade convenção de arbitragem, rompe o pactuado. Pode-se visualizar este rompimento em duas hipóteses: a) a negativa de efetivação da cláusula dita "vazia"; e b) atos obstantes à cláusula dita "cheia".

A cláusula compromissória dita vazia ou branca é aquela que não contém mecanismos próprios para a instituição da arbitragem. ${ }^{232}$ Contudo, permanecem com ela os efeitos positivos e negativos inerentes à convenção de arbitragem, ${ }^{233}$ sendo necessário apenas o aporte dos elementos faltantes para sua devida efetivação através do procedimento trazido pelos arts $6^{\circ}$ da LArb, ${ }^{234}$ por meio do compromisso firmado em juízo afim de completar a

\footnotetext{
${ }^{230} \mathrm{O}$ princípio de proibição do comportamento contraditório não está expressamente positivado no Código de 2002. Contudo, afirma Schreiber que da conjugação dos artigos 172, 491, 619 e, principalmente, 476, pode-se extrair a presença implícita deste importante princípio. (SCHREIBER, Anderson. "A proibição de comportamento contraditório: tutela da confiança e venire contra factum proprium". Rio de Janeiro: Renovar, $2^{\mathrm{a}}$ ed., 2007, p77). Esta lição está em consonância com o Enunciado n. 362, realizado na IV Jornada de Direito Civil do Conselho da Justiça Federal, cujo teor é o seguinte: "Art. 422. A vedação do comportamento contraditório (venire contra factum proprium) funda-se na proteção da confiança, tal como se extrai dos arts. 187 e 422 do Código Civil."

${ }^{231}$ SCHREIBER, Anderson. Op. Cit., p96.

${ }^{232}$ MARTINS, Pedro A. Batista. Op. Cit., p114.

${ }^{233}$ Em linhas gerais, o "efeito positivo" da cláusula compromissória consiste na imposição de instituição do tribunal arbitral para dirimir a querela, ao passo que o "negativo" importa no afastamento da via judicial.

${ }^{234}$ Art. $6^{\circ}$ Não havendo acordo prévio sobre a forma de instituir a arbitragem, a parte interessada manifestará à outra parte sua intenção de dar início à arbitragem, por via postal ou por outro meio
} 
cláusula vazia. Portanto, a parte que recusa firmar o compromisso afim de "completar" a cláusula de arbitragem vazia contradiz a si mesma, incorrendo no chamado venire contra factum proprium. A existência de cláusulas vazias ou patológicas, como salienta José Emílio Nunes Pinto, deve ser evitada a qualquer custo, afim de que não seja frustrada a legítima expectativa gerada pelo negócio jurídico, em estrita observância ao dever de colaboração existente no trato negocial, por força do art. 422 do CC2002. ${ }^{235}$ Destarte, há na conduta do convenente que assim procede um duplo ilícito, tanto de natureza legal, quanto contratual, gerando responsabilidade de indenizar as perdas materiais decorrentes do ato ilícito, bem como o dano moral, caso existente. Neste sentido é a lição de Selma Ferreira Lemes:

\begin{abstract}
"Portanto, advirta-se, deixar de acatar cláusula compromissória regularmente pactuada pode, à luz dos deveres acessórios de conduta que defluem da cláusula geral da boa-fé, em especial a lealdade contratual, incidir em duplo ilícito (legal/contratual): violar a Lei de Arbitragem e o Código Civil, ensejando, além da instituição obrigatória da arbitragem (art. 41 da Lei n. 9.307/96), também a responsabilidade civil contratual, por acarretar tanto o dano material como o dano moral. A parte que inadimpliu o contrato pode ser obrigada a ressarcir os incômodos causados pela procrastinação da instauração da arbitragem. Ademais, as partes podem, ao redigir o contrato, estabelecer cláusula penal nesse sentido." 236
\end{abstract}

De igual forma, viola também a eticidade presente na proibição do comportamento contraditório o convenente que não obstante ter firmado convenção de arbitragem, lança mão de medidas protelatórias contrárias à arbitragem, tanto em sede arbitral, como na mora injustificada na nomeação dos árbitros que integrarão o painel, ${ }^{237}$ como na via judicial. Tais práticas anti-arbitragem vêm sendo combatidas na jurisprudência, como se analisa

qualquer de comunicação, mediante comprovação de recebimento, convocando-a para, em dia, hora e local certos, firmar o compromisso arbitral. Parágrafo único. Não comparecendo a parte convocada ou, comparecendo, recusar-se a firmar o compromisso arbitral, poderá a outra parte propor a demanda de que trata o art. $7^{\circ}$ desta Lei, perante o órgão do Poder Judiciário a que, originariamente, tocaria o julgamento da causa.

235 PINTO, José Emílio Nunes. Op. Cit., p39.

${ }^{236}$ LEMES, Selma Ferreira. “A Cláusula Compromissória e a Boa-Fé. Uma jurisprudência Pedagógica”, 2004, p7, encontrado em: www.selmalemes.com.br/artigos/artigo_juri02.pdf.

${ }^{237}$ SILVA, Eduardo Silva da. Op. Cit., p66. 
nos célebres casos Copel $^{238}$ e L'Aiglon vs. Textil União S. $A^{239}$, bem como a expressa referência ao princípio do venire contra factum proprium pelo TJMG no julgamento do Agravo de Instrumento n. 1.0024.08.307639$8 / 001 .^{240}$

${ }^{238} \mathrm{O}$ Caso Copel pode ser tomado como exemplo do pensamento pró-arbitragem presente da parte de muitos juízes e Tribunais brasileiros. Ao fundamentar seu didático voto no AgIn 174-874-9/02, o relator aponta a conduta totalmente inconveniente da Copel S.A em ajuizar medidas protelatórias ao processo arbitral em juízo, o que demonstra uma clara violação à boa-fé objetiva inter partes. Diz o acórdão: $\mathrm{O}$ art. $8^{\circ}$ da Lei 9.307/96 é taxativo ao estatuir que aos árbitros é atribuída a tarefa de "decidir as questões acerca da existência, validade e eficácia ... do contrato que contenha a cláusula compromissória". Em outras palavras, evidente que a Câmara Arbitral somente poderá dispor sobre a cobrança de valores quando o ato jurídico for válido, assim como poderá interpretar o contrato como ineficaz. A análise sobre a validade da avença depende, por óbvio, da interpretação contratual e nisto se inclui a sua validade, a declaração de inadimplemento e conseqüente condenação. $\mathrm{O}$ árbitro não pode somente condenar, sem fazer uma prévia análise acerca da eficácia do contrato, porquanto a análise que conduz a esta condenação é indispensável. Por isso, afirmo que as alegações da COPEL não são maduras, mas sim, inconvenientes, e visam, em última análise, impedir, por via oblíqua (a propalada ação popular), alterar todo o regime jurídico instituído pela Lei 9.307/96. Seria muito conveniente eleger um árbitro, pagar por isso (com dinheiro público, frise-se) e depois, de maneira simplória, por meio de ações judiciais, alegar que o direito discutido na arbitragem é indisponível (compra e venda?!?!?) e, portanto, não pode prosseguir. Simplesmente ininteligível. (TJPR, $1^{\text {a }}$ Câmara, Agravo de Instrumento 174-874-9/02, Rel. Fernando César Zeni, dj: 10.05.2005)

${ }^{239}$ O Caso L'Aiglon vs. Textil União S.A representa um marco na realidade arbitral brasileira, por ter sido a primeira sentença arbitral estrangeira homologada pelo STJ, no julgamento da SEC 856. A relatoria do caso foi dada ao Min. Carlos Alberto Direito, cujo voto é extremamente didático. O contrato entre os convenentes tratava de 2.000 toneladas métricas de algodão, e diante do inadimplemento parcial da Têxtil União, a sentença arbitral da Liverpool Cotton Association $L C A$ condenou a parte brasileira em $\mathrm{R} \$ 910.000,00$, que, não obstante ter deixado de indicar árbitro, apresentou farta documentação de defesa durante o processo arbitral, demonstrando claramente sua participação no mesmo. Contudo, alegou em juízo que não podia ser a sentença homologada por conta de sua nulidade, já que não aceitou expressamente a convenção de arbitragem. Entendeu o relator, acertadamente, que não havia nulidade na sentença por ter a Têxtil União dado provas inequívocas de sua vontade em participar da arbitragem. Este é, portanto, um claro exemplo da proibição de comportamento contraditório. (STJ, SEC 856-EX, Corte Especial, Rel. Min. Carlos Alberto Menezes Direito, dj.18.05.2005).

${ }^{240} \mathrm{Um}$ exemplo da aplicação do venire contra factum proprium nos tribunais é o acórdão cuja ementa e trecho do voto trazemos à colação: TJMG, $17^{\mathrm{a}}$ Câmara Cível, Agravo de Instrumento n. 1.0024.08.307639-8/001, Rel. Des. Luciano Pinto, Dj: 26.03.2009 AGRAVO DE INSTRUMENTO - AÇÃO ANULATÓRIA DE PROCEDIMENTO ARBITRAL ANTECIPAÇÃO DA TUTELA - SOBRESTAMENTO DO PROCEDIMENTO ARBITRAL VÍCIO DE REPRESENTAÇÃO - INOCORRÊNCIA - COMPARECIMENTO DAS PARTES JUNTADA DE PROCURAÇÃO COM PODERES ESPECIAIS - VEROSSIMILHANÇA DA ALEGAÇÃO - AUSÊNCIA - DECISÃO NÃO FUNDAMENTADA - CASSAÇÃO QUE SE IMPÕE. Restando demonstrado pelos agravantes, na qualidade de terceiros interessados, que o alegado vício de representação em que se sustenta a ação anulatória de procedimento arbitral, foi satisfatoriamente suprido, não só pelo comparecimento das partes e de seus procuradores por ocasião da assinatura do Termo de Compromisso Arbitral, como também, pela juntada, no referido procedimento, de instrumento de procuração que conferiu aos patronos dos agravantes poderes especiais para atuação em tal sede, ausente a verossimilhança da alegação de que o procedimento administrativo encontra-se maculado e deve ser anulado, e mostra-se injustificável o deferimento da antecipação da tutela para sobrestar o andamento dele. Mostra-se carente de fundamentação a decisão que se sustenta em premissa de caráter geral, cabível em qualquer arcabouço expressional, pois a simples alegação de que presente no caso em análise a verossimilhança da alegação da 


\subsection{Autonomia e deveres laterais: um olhar para a confidencialidade}

Por conseguinte, incide o dever de boa-fé não apenas na negociação do contrato, mas ao longo toda a relação entre os convenentes. A doutrina moderna entende a obrigação como um processo, ${ }^{241}$ e esta relação prolonga-se no tempo, afetando a boa-fé não somente a conclusão e execução do contrato, mas também as fases pré $^{242}$ e pós-negocial, ${ }^{243}$ (inclusive ao seu adimplemento) afim de ter-se a realização do objetivo do contrato, sendo este holisticamente considerado. Criou-se, por conseguinte,

parte, não se presta a dar validez ao argumento, haja vista que não fere o caso concreto, justificando sua cassação. (...) De resto, como se vê a f. 252-TJ, também a requerida, ora agravada, quando do encetamento do Compromisso Arbitral, compareceu por intermédio de mandatário, que apôs o "p.p." logo em seguida a sua assinatura, de modo que a atitude da agravada, agora, ao verberar o comparecimento da agravante, àquele ato, por via de mandatário, quando ela, agravada, também o fez, implica a incidência, em desfavor da agravada, do venire contra factum proprium, o que contraria o direito. A proibição do venire contra factum proprium implica exatamente a impossibilidade de se pretender anular contratos ou títulos fundados em fato para cuja perfeição concorreu o próprio sujeito que brande o argumento da invalidade. Nas fontes romanas do direito civil a vedação já existia no turpitudinem suam allegans non auditur (aquele que alega a sua torpeza não deve ser ouvido) bem como no adversus factum suum movere controversias prohibetur (contra um fato próprio, não se pode mover ação de impugnação), (...) O venire contra factum proprium figura parcelar da boa-fé objetiva, como anota Luciano de Camargo Penteado, no ensaio acima citado é de ser aplicado em qualquer caso, porque a matéria de boa-fé é de ordem pública e incide em qualquer momento, mesmo em contratos encetados antes do Novo Código Civil, haja vista que, como no caso presente, os efeitos são contemporâneos. Por isso, não há falar em nulidade do compromisso arbitral e do procedimento que a ele se seguiu, por alegada ilegalidade de representação de preposto, mesmo porque o comparecimento do advogado, ao ato do Compromisso Arbitral, como representante da parte, configurou ato único, que ali se esgotou (o que não se confunde com os efeitos daquele ato, que se postam como irradiações a sustentar o Procedimento Arbitral, mas o ato continua sendo único)."

${ }^{241}$ Concepção difundida por Clóvis Couto e Silva; cf. SILVA, Clóvis do Couto e. "A obrigação como processo". Rio de Janeiro: Fundação Getulio Vargas, 2007

242 "Esqueceu-se o legislador de incluir expressamente na fórmula do art. 422 os períodos pré e pós-contratual, dentro dos quais o princípio da boa-fé tem importância fundamental para a criação de deveres jurídicos para as partes, diante da inexistência nessa fase de prestação a ser cumprida. Essa omissão não implica negação da aplicação da regra da boa-fé para essas fases antecedente e posterior ao contrato, muito pelo contrário, já que cabe aqui a interpretação extensiva da norma para abranger também as situação não expressamente referidas, mas contidas no seu espírito." (PEREIRA, Caio Mário da Silva. Op. Cit., p20).

243 "Quanto à extensão do princípio da boa-fé, em si considerado, a despeito da referência literal do dispositivo à conclusão e à execução do contrato, entende-se que o comando deve incidir também na fase pós-negocial, ao longo do qual os ex-contratantes ainda devem se manter vinculados pelo mesmo princípio. Tal entendimento justifica-se na esteira da doutrina que compreende a obrigação como processo dinâmico e funcionalmente determinado" (TEPEDINO, Gustavo, et al. Op. Cit., p16); neste mesmo sentido: PINTO, José Emílio Nunes. Op. Cit., p41. Cf. também: STJ, Terceira Turma, REsp n. 1.255.315-SP, Rel. Min. Nancy Andrighi, dj. 13.09.2011. Assim é também o teor do Enunciado n ${ }^{\circ}$ 25, do CJF: “Art. 422: o art. 422 do Código Civil não inviabiliza a aplicação pelo julgador do princípio da boa-fé nas fases pré-contratual e pós contratual." 
a doutrina da culpa post factum finitum, que ganhou guarida na jurisprudência. ${ }^{244}$

Diante disso, os ditos deveres anexos decorrentes da cláusula geral da boa-fé, sintetizados como deveres de proteção e cooperação, alargam a hipótese fática de inadimplemento, com o consequente dever de indenizar diante de sua violação ainda que terminada a prestação. Por conseguinte, como bem ressaltam Gustavo Tepedino, Heloisa Barboza e Maria Celina Bodin de Moraes, tais deveres "não se podem exaurir por meio de catálogos abstratos e apriorísticos", ${ }^{245}$ devendo ser levado em conta a própria natureza do vínculo, bem como o caso concreto da relação obrigacional. Em sede de arbitragem, estes deveres anexos são devidos ainda que terminado o processo arbitral. Vale dizer que a convenção de arbitragem inserta em contrato não apenas estipula os efeitos positivo e negativo acerca do foro, mas também todos os deveres inerentes aos negócios jurídicos trazidos pelo direito civil-constitucional, colocados ao lado das prestações fruto da autonomia privada. Neste sentido, ensina Jorge Cesa da Silva:

\begin{abstract}
"boa-fé expande as fontes dos deveres obrigacionais, posicionando-os ao lado da vontade e dotando a obrigação de deveres orientados a interesses distintos dos vinculados estritamente à prestação" ${ }^{246}$
\end{abstract}

Com efeito, faz-se referência à importante valoração do dever de confidencialidade, que não obstante vir sendo reconsiderado em outros

\footnotetext{
${ }^{244}$ TJRS, Quinta Câmara Cível, Apelação Cível n. 588042580, Rel. Des. Ruy Rosado de Aguiar Jr., dj:16.08.1988, cuja ementa é a seguinte: "Compra e venda. Resolução. Culpa post pactum finitum. $\mathrm{O}$ vendedor que imediatamente após a venda torna inviável a compradora dispor do bem, ameaçando-a de morte e a escorraçando do lugar, para aproveitar-se disso e vender a casa para outrem, descumpre uma obrigação secundária do contrato e dá motivo à resolução. Principio da boa fé. (...)". Neste mesmo sentido é o acordão do TJSP: “(...) ocorreu a culpa 'post factum finitum', incidindo a pós-eficácia obrigacional, que leva à imposição de multa, por não se garantir a fruição do avençado" (TJSP, $11^{\text {a }}$ Câmara de Direito Público, Apelação 570.190.5/7-00, Rel. Des. Francisco Vicente Rossi, dj. 27.11.2007); cf. também, TJSP, 4 a Câmara, Apelação Cível n. 994.09.30086-0, Rel. Des. Ênio Zuliani, dj. 07.10.2010;

${ }^{245}$ TEPEDINO, Gustavo et al., Op. Cit. p19.

${ }^{246}$ SILVA, Jorge Cesa Ferreira da. "A boa-fé e a violação positiva do contrato". Rio de Janeiro: Renovar, 2002, p270.
} 
países, ${ }^{247}$ ainda é característica inerente à realidade arbitral pátria. ${ }^{248} \mathrm{O}$
dever de confidencialidade, e sua devida salvaguarda antes e depois do

${ }^{247}$ O célebre caso Dolling-Baker vs. Merrett, julgado em 1990, deu o tom nas discussões acerca do dever de sigilo entre as partes numa arbitragem. Comentando o caso, escrevem Claude R. Thomson e Annie M. K. Finn: "in Dolling-Baker v. Merrett, the English Court of Appeal found that an implied obligation of confidentiality existed in the arbitration process. This obligation extended to documents prepared in contemplation of arbitration or used in the process, transcripts, notes of evidence, testimonial evidence, and the award." (Em tradução livre: em Dolling-Baker v Merrett, a Court of Appeal inglesa considerou que uma obrigação implícita de confidencialidade existia no processo arbitral. Esta obrigação se estende aos documentos preparados na instituição da arbitragem ou usados no processo, transcrições, notas de prova, provas testemunhais, e a sentença). Contudo, o Caso Esso trouxe novos ares à discussão, uma vez que a Suprema Corte Australiana entendeu não ser a confidencialidade um atributo essencial à arbitragem: "In the controversial Australian case Esso Australia Resources Ltd. et al. v. Plowman , which concerned a dispute between Esso and the Australian Minister for Energy and Minerals over public utilities and information related to the prices charged to the public, the High Court of Australia held that confidentiality was not an essential attribute of the arbitral process." ("No polêmico caso australiano Esso Australia Resources Ltd. et al. vs Plowman, que tratou de litígio entre a Esso e o Ministro australiano de Minas e Energia acerca de utilidades públicas e informações relacionados aos preços cobrados ao público, a Suprema Corte Australiana afirmou que a confidencialidade não é um atributo essencial ao processo arbitral"). Já no caso Bulbank, outro célebre sobre o assunto, a Corte de Apelação da Suécia entendeu não haver um dever legal de confidencialidade: "In the Swedish case, A.I. Trade Finance Inc. v. Bulgarian Foreign Trade Bank Ltd. (Bulbank), the Swedish Court of Appeal held that there is no implied in law duty of confidentiality in arbitration." ("No caso suéco A.I. Trade Finance Inc. vs. Bulgarian Foreign Trade Bank Ltd. (Bulbank), a Corte de Apelações da Suécia entendeu não haver um dever legal imposto de confidencialidade na arbitragem.”). Nos EUA, faz-se referência ao caso Panhandle Eastern Corp., em que afirmou-se não haver também na arbitragem este dever de sigilo, contanto que não haja cláusula de arbitragem ou regulamento de instituição prevendo expressamente que o procedimento será sigiloso. (THOMSON, Claude R., FINN, Annie M. K. "Confidentiality in Arbitration: a valid assumption? A proposed solution". In: Dispute Resolution Journal. New York: American Arbitration Association, vol. 62, n. 2, 2007, p3-4. Dolinger e Tiburcio apresentam também casos nas cortes inglesas (Hassneh Ins. Of Israel vs. Mew) e francesas (Aïta vs. Ojjeh) partidários da confidencialidade absoluta em arbitragem. (DOLINGER, Jacob e TIBURCIO, Carmen. Op. Cit., p83).

${ }^{248}$ A LArb é parcialmente silente sobre o dever de confidencialidade. Aos árbitros é previsto no art.13, $\S 6^{\circ}$ o dever de discrição, que os impõe o dever de sigilo em relação aos documentos, informações e atos ao longo de todo o processo arbitral, conforme entendimento da doutrina (cf. PINTO, José Emílio Nunes...). Todavia, em relação às partes, não há qualquer comando expresso na lei em relação ao dever de sigilo. Contudo, este dever não decorre de um comando legal, e sim da inteligência do sistema como um todo. A forte relação entre arbitragem e confidencialidade no direito pátrio é evidenciada pela presença unânime do dever de sigilo nas regras de procedimento das mais importantes câmaras de arbitragem brasileiras. O regulamento da CCBC (Câmara de Comércio Brasil-Canadá) traz o dever de sigilo nos seguintes dispositivos: "9.8. O procedimento arbitral é rigorosamente sigiloso, dele participando somente as pessoas que tenham legítimo interesse. Nas audiências o presidente do Tribunal Arbitral diligenciará para que qualquer testemunha se retire do recinto da audiência durante o depoimento das partes ou de outras testemunhas." e "9.9. É vedado aos membros do Centro, aos árbitros e às partes divulgar quaisquer informações a que tenham tido acesso em decorrência de ofício ou de participação no procedimento arbitral." Por conseguinte, o regulamento da Câmara de Arbitragem e Mediação de São Paulo diz: "Art. 6.2 O processo arbitral é sigiloso e confidencial sendo vedado as partes, aos árbitros, aos membros da Câmara e às pessoas que tenham participado no referido processo, divulgar informações a ele relacionadas.”; já o regulamento da carioca CBMA (Câmara de Mediação e Arbitragem" faz referência à exceção legal sobre sigilo em arbitragens envolvendo a Administração Pública: "Confidencialidade 15.1 Salvo acordo em contrário das partes, ou se exigido por lei aplicável às partes, os membros do Tribunal e do Centro manterão confidencialidade sobre os assuntos relacionados à arbitragem, salvo aqueles porventura já de 
processo arbitral, como aponta José Emílio Nunes Pinto, é expressão, portanto, da boa-fé objetiva:

\begin{abstract}
"no campo arbitral, diríamos que o sigilo sobre o procedimento arbitral, dados e informações trazidos à discussão, e o teor mesmo da sentença arbitral é manifestação inequívoca de alinhamento com o princípio da boa-fé, expresso na confiança que deve prevalecer na relação entre as partes e fundada no dever legal de proteção." 249
\end{abstract}

Por conseguinte, a quebra deste dever de confidencialidade, isto é, a divulgação não autorizada da existência do litígio, bem como quaisquer atos e documentos referentes à arbitragem importa em violação positiva da convenção de arbitragem, e caso demonstrado o dano conexo à tal quebra, tem-se o dever de indenizar. Contudo, não somente em relação ao dever de confidencialidade, mas quaisquer outros deveres conexos, caso não respeitados, geram este dever de reparação. Cite-se, como exemplo, o convenente que mesmo sabedor que num dado país impera norma de ordem pública que implique em nulidade da sentença arbitral a ser executada naquele território, ainda assim manifesta sua vontade para escolha de lei que caso aplicada, viola tal preceito. Tem-se, no caso hipotético, violação ao dever de informação inter partes.

Por fim, conclui-se que o Código Civil de 2002, na esteira do novo paradigma contratual, qualifica e protege a vontade das partes contratantes, que, mais uma vez salienta-se, estão em colaboração na relação jurídica

domínio público ou que já tenham sido de alguma forma divulgados. 15.2 O Centro poderá dar publicidade à sentença arbitral, caso previamente autorizada pelas partes ou, em caso negativo, poderá o Centro, de qualquer modo, divulgar excertos de sentença arbitral, desde que preservada a identidade das partes."; Outrossim, dispõe o regulamento da CIESP/FIESP: "Art. 17.4 - O procedimento arbitral é rigorosamente sigiloso, sendo vedado aos membros da Câmara, aos árbitros e às próprias partes divulgar quaisquer informações com ele relacionadas, a que tenham acesso em decorrência de ofício ou de participação no referido procedimento."; da mesma maneira, dispõe o art. 12.2 do regulamento do CONIMA: "Art. 12.2. O processo arbitral é sigiloso sendo vedado às partes, aos árbitros, aos membros da CÂMARA e às pessoas que tenham participado no referido processo, divulgar informações a ele relacionadas.”; de igual forma o regulamento da CAMARB (Câmara de Arbitragem Comercial-Brasil) em seu art. 12.1: "O procedimento arbitral será rigorosamente sigiloso, sendo vedado à CAMARB, aos árbitros e às próprias partes divulgar quaisquer informações a que tenham acesso em decorrência de seu ofício ou de sua participação no processo, sem o consentimento de todas as partes, ressalvados os casos em que haja obrigação legal de publicidade."

${ }^{249}$ PINTO, José Emílio Nunes. Op. Cit., p41. 
contratual. $\mathrm{O}$ atual regime contratual, antes de limitar a vontade, protege a mesma de eventuais abusos. ${ }^{250}$

\footnotetext{
${ }^{250}$ Assim salienta Nunes Pinto: “Como a lei especial (Lei de Arbitragem) não estabelece as relações no campo do direito material decorrentes da opção pela arbitragem e os deveres que são gerados às partes por tão opção, cumpre ao Código Civil um papel decisivo ao emprestar os critérios dos arts. 186 e 187. Sendo ainda um texto a se construir, a cláusula geral da boa-fé impõe às partes outros deveres, não fixados em lei, mas que são impostos para viabilização do próprio tráfego negocial. Condutas das partes entre si, das partes em relação aos árbitros e das partes em relação a eventual câmara arbitral que não poderem se subsumir dentro do modelo de comportamento do homem reto, estarão sujeitas à reprovação e darão causa à responsabilização civil, independentemente da tutela específica pretendida. Registre-se, no amplo rol de possibilidades que se descortina, o dever geral de informação que determina que cada parte, em relação à outra e aos demais personagens, seja transparente ao que deixa de juntar documento importante para o deslinde da demanda ou que, por outro lado, não informa à câmara arbitral dados relacionados à personalidade jurídica do demandante ou demandado.” (PINTO, José Emílio Nunes. Op. Cit., p68).
} 


\title{
5. Autonomia privada e arbitragem no plano internacional
}

A relação entre a autonomia da vontade e o instituto da arbitragem é de tal ordem que esta apenas existe em razão daquela. Não há arbitragem sem vontade. É neste campo de liberdade que, segundo Pedro Batista Martins, a arbitragem é "exercida", observando na autonomia da vontade o próprio espírito do instituto:

\begin{abstract}
"alinha-se, enfim, com o espírito do instituto que se calca na autonomia da vontade. Por isso afirmo que a arbitragem não é praticada, ela é exercida, pois manejada em um cenário de liberdade. Desde seu surgimento a arbitragem se exercita numa atmosfera de plena autonomia, alimentada pela vontade das partes em afastar determinado ordenamento ou foro, no interesse dos convenentes e por circunstâncias que as partes não negam e que lhes são próprias. Princípio e escolha que não são defesas às partes; ao contrário, são facultadas que compõem o patrimônio jurídico dos indivíduos."251
\end{abstract}

Ainda nesta toada, explicam Luiz Olavo Baptista e Sílvia Julio Bueno de Miranda:

\footnotetext{
"No direito brasileiro, assim como na maioria dos sistemas legais, a arbitragem repousa sobre duas colunas: a autonomia da vontade das partes e o respeito pelo contrato." 252
}

Com efeito, as partes escolhem afastar-se do foro estatal (ou ainda, escolhem afastar-se de um determinado ordenamento jurídico), escolhem o número de árbitros e quem serão estes, escolhem se será uma arbitragem institucional (administrada por alguma das célebres câmaras arbitrais, tais como AAA, CCI, FGV, etc.) ou ad hoc, e qual será o procedimento a ser observado, escolhem o prazo para prolatar-se a sentença, escolhem o idioma, e ainda, escolhem a sede da arbitragem. Como ensina Selma Ferreira Lemes, a autonomia da vontade encontra na arbitragem a sua quinta-essência:

\footnotetext{
${ }^{251}$ MARTINS, Pedro A. Batista, Op. Cit., p46.

${ }^{252}$ BAPTISTA, Luiz Olavo e MIRANDA, Sílvia Julio Bueno de., "Convenção de arbitragem e escolha da lei aplicável: uma perspectiva do direito brasileiro", In: Revista de Arbitragem e Mediação, WALD, Arnoldo (Coord.). São Paulo: Revista dos Tribunais, n. 27, outubro-dezembro, $2010, \mathrm{p} 12$.
} 
“O princípio da autonomia da vontade é a mola propulsora da arbitragem em todos os seus quadrantes, desde a faculdade de as partes em um negócio envolvendo direitos patrimoniais disponíveis disporem quanto a esta via opcional de solução de conflitos $\left(\operatorname{art.~} 1^{\circ}\right.$ ), até como será desenvolvido o procedimento arbitral no que pertine à forma de indicação dos árbitros (art. 13): a lei aplicável à arbitragem, seja material ou formal, desde que não viole os bons costumes e a ordem pública (art. $2^{\circ}$, parags. $1^{\circ}$ e $2^{\circ}$ ); se a decisão será de direito ou equidade (art. $2^{\circ}$ ); eleger a arbitragem institucional (art. $5^{\circ}$ ); prazo para o árbitro proferir a sentença arbitral (arts. 11, inciso III e 23). Enfim, o princípio da autonomia da vontade atinge sua quinta-essência na Lei $\mathrm{n}$. 9.307/96." ${ }^{253}$

Diante desta realidade, cumpre analisar como a autonomia se expressa na arbitragem, tanto no plano interno, como no plano internacional.

\subsection{Autonomia e arbitragem na lei aplicável}

Como foi tratado na primeira parte deste trabalho, no plano internacional a autonomia da vontade reveste-se de um significado a mais em comparação com sua expressão no plano interno. Em síntese, permanece o dogma que diz "tudo o que não é proibido, é permitido.” Já em âmbito internacional, a autonomia toca a liberdade das partes na escolha da lei aplicável ao contrato. Vale notar que a autonomia, em seu sentido doméstico, estará igualmente presente nesta relação, mas no que tange ao conteúdo do contrato. ${ }^{254}$

Ora, como tratado anteriormente, a regra de conflito de leis concernentes às obrigações internacionais em nosso direito pátrio é a do art. $9^{\circ}$ da LINDB, que prevê a lex loci contractus, i.e., a lei do local onde o contrato foi celebrado, para definir qual ordenamento deve ser aplicado no caso concreto, em que pese as exceções convencionais, bem como as diversas posições e críticas sobre o assunto. ${ }^{255}$ Contudo, conforme salientam Luiz Olavo Baptista e Sílvia Miranda, o destinatário da norma de

\footnotetext{
${ }^{253}$ LEMES, Selma M. Ferreira. Op. Cit., p32.

${ }^{254}$ BAPTISTA, Luiz Olavo e MIRANDA, Sílvia Julio Bueno de. Op. Cit., p14.

${ }^{255}$ Reportamos ao capítulo 2 deste trabalho, principalmente na parte referente à inteligência da regra contida no art. $9^{\circ}$ da Lei de Introdução Brasileira.
} 
conexão é o julgador da matéria, e não os convenentes. Destarte, isto significa que quando as partes exercem a arbitragem, outra norma de conexão será aplicada:

"A LICC [leia-se, LINDB] dispõe que contratos internacionais deverão ser regidos pela lei do local onde as obrigações contratuais foram constituídas (lex loci celebrationis). Mas essa regra é um comando endereçado ao juiz, que ignora a existência de qualquer disposição contratual adotando uma lei para governar o contrato. (...) Finalmente (...) quando as partes escolhem resolver suas disputas por arbitragem, uma diferente e específica regra de conflito de leis será aplicada." ${ }^{256}$

Ora, tal regra de conexão é aquela contida no art. $2^{\circ}, \S 1^{\circ}$ da LArb, que diz o seguinte:

Art. $2^{\circ} \mathrm{A}$ arbitragem poderá ser de direito ou de equidade, a critério das partes.

$\S 1^{\circ}$ Poderão as partes escolher, livremente, as regras de direito que serão aplicadas na arbitragem, desde que não haja violação aos bons costumes e à ordem pública.

$\S 2^{\circ}$ Poderão, também, as partes convencionar que a arbitragem se realize com base nos princípios gerais de direito, nos usos e costumes e nas regras internacionais de comércio. (ênfase dada)

Em que pese a existência de outros critérios na legislação comparada para a aplicação da lei estrangeira, ${ }^{257}$ quis o legislador pátrio adotar a plena autonomia da vontade como regra de conexão aos contratos submetidos à arbitragem. O peso da autonomia da vontade é tal, que o legislador lançou mão do advérbio "livremente" para qualificar a vontade das partes. Portanto, não obstante a incerteza gerada no direito internacional pátrio quanto a escolha da lei aplicável, sob o regime arbitral não paira dúvidas:

\footnotetext{
${ }^{256}$ BAPTISTA, Luiz Olavo e MIRANDA, Sílvia Julio Bueno de. Op. Cit., p17. Os autores usam a expressam "lex loci celebrationis", por entenderem que o termo "lex loxi contractus" não é tão preciso, por ter o lugar de celebração do contrato papel fundamental na regra de conexão. Contudo, o efeito prático é o mesmo.

257 "Observando outras legislações, sem surpresa percebe-se que diferentes países adotam diferentes critérios com relação à aplicação do direito estrangeiro nas arbitragens. O critério mais comum é baseado na distinção entre arbitragens domésticas e internacionais: por esse ponto de vista, a lei estrangeira pode apenas ser aplicada nas arbitragens internacionais. O segundo critério é baseado na internacionalidade do objeto da arbitragem. Ou seja, contratos internacionais deverão ser submetidos à lei estrangeira, enquanto contratos domésticos poderão apenas ser submetidos à lei nacional.” (BAPTISTA, Luiz Olavo e MIRANDA, Sílvia Julio Bueno de. Op. Cit., p20). Sobre a questão da arbitragem interna ou internacional, ver adiante.
} 
respeita-se a vontade das partes, o que é deveras proveitoso para a realidade negocial brasileira. ${ }^{258}$ Neste sentido, ensina Carlos Alberto Carmona:

\begin{abstract}
“[Na LArb] prestigiou-se em grau máximo e de modo expresso o princípio da autonomia da vontade, de forma a evitar dúvidas na aplicação da lei. Sabe-se que no Brasil o princípio da autonomia da vontade encontra alguma dificuldade em sua aplicação, afirmando Irineu Strenger que o princípio foi abandonado pela Lei de Introdução ao Código Civil (...). Em sede de arbitragem, porém, muitos problemas são resolvidos com a expressa escolha da lei aplicável pelas próprias partes, de tal sorte que o árbitro não terá de recorrer às regras de conflitos de leis para estabelecer a norma que regerá o caso concreto., 259
\end{abstract}

Destarte, a LArb instaurou um regime especial aos contratos que estejam submetidos à arbitragem: excepciona-se a norma do polêmico art. $9^{\circ}$ da LINDB e aplica-se a regra de conexão própria da arbitragem, qual seja, a escolha livre das partes. Conforme lição de Pedro Batista Martins:

"Não há que se pensar, tampouco, na disposição contida no art. $9^{\mathrm{o}}$ da LICC, pois estranha aos contratos submetidos à arbitragem. A escolha da lei que vai ser adotada para solucionar a demanda submetida à arbitragem não sofre qualquer limitação porventura existente na Lei de Introdução. Na arbitragem as partes são livres para exercerem a opção." 260

Este é também o posicionamento jurisprudencial sobre a matéria, em que pese o reconhecimento de haver apenas um caso sobre o assunto. Tratase do leading case entre nós: o voto vanguardista do Des. Juiz Souza José, no Agravo de Instrumento n. 1.111.650-0, julgado pela $7^{\mathrm{a}}$ Câmara do $1^{\mathrm{o}}$ Tribunal de Alçada Civil de São Paulo:

“(...) não há invocar-se a LICC, que só tem aplicação quando houver omissão ou controvérsia a respeito do direito aplicável à hipótese. Como a Lei 9.307/1996, em seu art. $2^{\circ}$, permite que as partes possam livremente escolher as regras de direito que serão

\footnotetext{
${ }^{258}$ Neste sentido: "A arbitragem tornou-se popular em transações internacionais porque oferece às partes litigantes maior previsibilidade com relação à lei aplicável e ao fórum do que as disputas jurídicas no tribunal." (MOROSINI, Fábio, "Globalização e Direito: além da metodologia tradicional dos estudos jurídicos comparados a um exemplo do Direito Internacional Privado", In: Revista de informação legislativa, v.43, n. 172, outubro/dezembro de 2006, p.129).

${ }^{259}$ CARMONA, Carlos Alberto. Op. Cit., p34.

${ }^{260}$ MARTINS, Pedro A. Batista. Op. Cit. p46.
} 
aplicadas na arbitragem, não se verifica o impedimento arguido." ${ }^{261}$

Por conseguinte, vale dizer ainda que esta autonomia das partes para escolha do direito aplicável se dá não somente nas regras substantivas, ou seja, aquelas aplicadas ao mérito. Ainda que alguns doutrinadores apontem uma certa ambiguidade da redação do art. $2^{\circ}, \S 1^{\circ}$ da LArb acerca de que regras são ali $\operatorname{tratadas}^{262}$, se substanciais apenas, ou igualmente de procedimento, a melhor doutrina aponta que a escolha é de fato igualmente livre e ampla para estas duas. Neste sentido, posicionam-se Nadia de Araujo e Lauro Gama Jr., ${ }^{263}$ Fabiane Verçosa, ${ }^{264}$ Pedro Batista Martins ${ }^{265}$. Em sentido contrário, contudo, posiciona-se Maristela Basso. ${ }^{266}$ Contudo, parece-nos equivocada a posição desta autora, uma vez que a liberdade de escolha, essência da arbitragem, é garantida expressamente pelo próprio texto legal tanto às regras substanciais, quanto às procedimentais, pelo art. 21 da LArb. ${ }^{267}$

\footnotetext{
${ }^{261}$ TJSP, $1^{\circ}$ TACSP, Agravo de Instrumento n. 1.111.650-0, $7^{\mathrm{a}}$ Câmara, Rel. Des. Juiz Souza José, dj. 24.09.2002. Teceremos maior análise sobre a importância deste julgado posteriormente.

${ }^{262}$ Como aduz Fabiane Verçosa: "em face da ambígua e imprecisa redação do art. $2^{\circ}, \S 1^{\circ}$, que estipula simplesmente que "poderão as partes escolher, livremente, as regras de direito que serão aplicadas à arbitragem", instaurou-se grande dúvida quanto à sua interpretação. De fato, não resta claro a que aspecto da arbitragem referiu-se o legislador ao outorgar às partes a possibilidade de escolha da lei aplicável." (VERÇOSA, Fabiane. Op. Cit., p441). Neste mesmo sentido, Lee argumenta: “a expressão 'regras de direito' que serão aplicadas na arbitragem' é imprecisa e pode gerar dificuldades quanto à sua interpretação.” (LEE, João Bosco. Op. Cit., p353.)

263 "A Lei n. 9.307/96 prestigiou, ainda, a autonomia da vontade das partes, de tal sorte que aos contratantes foi conferida ampla liberdade de escolha das normas aplicáveis, tanto ao procedimento quanto ao fundo da causa (...)" ARAUJO, Nadia e SOUZA JR., Lauro Gama. Op. Cit., p78.

264 "Em vista de todo o exposto, partilhamos da opinião daqueles que estendem aos aspectos processuais da arbitragem a autonomia da vontade para eleger a lei aplicável a este aspecto da arbitragem, não restringindo a lex voluntatis ao mérito da controvérsia." (VERÇOSA, Fabiane. Op. Cit., p445.)

265 "As regras de direito postas à livre escolha das partes são de cunho processual ou procedimental quanto substancial.” (MARTINS, Pedro A. Batista. Op. Cit., p46) E ainda, ao comentar o art. 21 da LArb, afirma que "as partes são livres para estabelecer o procedimento que os guiará à resolução do conflito." (Ibidem, p235).

266 "Quando o legislador se refere às 'regras de direito' está se referindo tanto às regras substanciais quanto às processuais? Estamos diante de problema de interpretação de dispositivo legal, o que não é tarefa fácil. Contudo, acreditamos que o legislador está se referindo apenas às regras de direito material, substancial (...)" (BASSO, Maristela, Apud VERÇOSA, Fabiane. Op. Cit. p442)

${ }^{267}$ Art. 21. A arbitragem obedecerá ao procedimento estabelecido pelas partes na convenção de arbitragem, que poderá reportar-se às regras de um órgão arbitral institucional ou entidade
} 


\title{
5.2 Relação entre as regras de conexão: revogação ou convivência?
}

Como dito acima, em contratos com cláusula arbitral a regra de conexão aplicada é a lex voluntatis. Contudo, encontra-se na doutrina divergência acerca do fundamento dessa aplicação. Em outras palavras, o que se dá no mundo jurídico diante da relação entre estas duas normas? Há conflito? E caso existente, qual o critério para superar a antinomia? ${ }^{268}$ Descortinam-se duas posições acerca da matéria. Gize-se que ambos concordam com a inaplicabilidade da regra de conexão do art. $9^{\circ}$ da LINDB, i.e., a lex loci celebrationis, contudo, possuem diferentes fundamentos.

Luiz Olavo Baptista argumenta que há conflito entre as duas regras de conexão, sendo aplicada a autonomia da vontade pelo fato de ter o art. $2^{\circ}, \S 1^{\circ}$ da LArb revogado, ${ }^{269}$ nos contratos com arbitragem, a regra do art. $9^{\circ}$ da LINDB. Esta revogação se dá pelo fato de ser a LArb mais recente, e mais específica que a LINDB:

\begin{abstract}
"Como a lei de arbitragem é mais recente e mais específica que a LICC, suas disposições referentes à autonomia da vontade das partes revogam as disposições da LICC sempre que um contrato inclua uma cláusula arbitral. Por consequência, as partes são livres para aplicarem sua escolha, que não é sujeita às limitações impostas pela LICC. ${ }^{270}$
\end{abstract}

\footnotetext{
especializada, facultando-se ainda, às partes delegar ao próprio árbitro, ou ao tribunal arbitral, regular o procedimento."

${ }^{268} \mathrm{Na}$ clássica lição de Norberto Bobbio, antinomia significa "encontro de duas proposições incompatíveis, que não podem ser ambas verdadeiras, e, com referência a um sistema normativo, encontro de duas normas que não podem ser ambas aplicadas, a eliminação do inconveniente só poderá consistir na eliminação de uma das duas normas (em caso de normas contrárias, também na eliminação de ambas). (BOBBIO, Norberto. "Teoria Geral do Direito". São Paulo: Martins Fontes, 2008, p237.)

${ }^{269}$ Caio Mario da Silva Pereira explica o que conceito de revogação: "Pelo princípio da continuidade, a lei somente perde a eficácia em razão de uma força contrária à sua vigência. $\mathrm{E}$ tal força é a revogação, consistente na votação de outra lei, com a força de fulminar a sua obrigatoriedade. A revogação pode ser total ou parcial, por atingir a totalidade ou apenas uma parte de seus dispositivos. À revogação total dá-se o nome de ab-rogação; a parcial chama-se de derrogação, apagando a primeira a eficácia completa da lei anterior, e atingindo a segunda apenas uma parte dela, enquanto deixa íntegras as disposições não alcançadas (...). Derrogada, a lei não fenece, não sai de circulação jurídica, mas é amputada nas partes ou dispositivos atingidos, que apenas estes perdem a obrigatoriedade." (SILVA, Caio Mário Pereira da. Op. Cit., p124)

${ }^{270}$ BAPTISTA, Luiz Olavo e MIRANDA, Sílvia Julio Bueno de. Op. Cit., p22.
} 
Ora, seguindo a linha exposta pelo doutrinador, lex posterior derrogat priori, e sendo a LArb datada de 1996, enquanto que a Lei de Introdução é de 1942, haveria derrogação por ser a primeira posterior à segunda (lei posterior revoga lei anterior). Contudo, permitimo-nos discordar do ilustre doutrinador, havendo neste caso uma certa imprecisão técnica. A revogação pelo critério cronológico se dá apenas quando duas normas analisadas em conjunto têm escopo de aplicação geral, ou especial. Com efeito, a norma da LINDB é norma geral, enquanto que a norma da LArb é especial. Neste caso, independe a cronologia das normas para aferição de revogação. Por conseguinte, a tese de revogação pelo critério da especialidade, embora trate a hipótese de lei especial diante de lei geral, igualmente não deve ser acolhida.

Assim o é pois, em matéria de revogação tácita, mister perquirir se há ou não, na hipótese, incompatibilidade. Havendo esta, normas incompatíveis não podem coexistir. ${ }^{271}$ Contudo, ao contrário dos dois outros métodos positivistas de conflito de normas (i.e., critério hierárquico e cronológico), o critério da especialidade não denota, em regra, incompatibilidade entre leis, tampouco cessa o convívio entre as leis. Assim explica Caio Mário da Silva Pereira:

\footnotetext{
"Esta coexistência não é afetada, quando o legislador vote disposições gerais a par de especiais, ou disposições especiais a par de gerais já existentes, porque umas e outras não se mostram, via de regra, incompatíveis. Não significa isto, entretanto, que uma lei geral nunca revogue uma lei especial, ou vice-versa, porque nela poderá haver dispositivo incompatível com a regra espacial, da mesma forma que uma lei especial pode mostrar-se incompatível com dispositivo incerto em lei geral. O que o legislador quis dizer (Lei de Introdução, art. $2^{\circ}, \S 2^{\circ}$ ) foi que a generalidade dos princípios numa lei desta natureza não cria incompatibilidade com regra de caráter especial. A disposição especial irá disciplinar o caso especial, sem colidir com a normação genética da lei geral, e, assim, em harmonia poderão vigorar." 272
}

\footnotetext{
${ }^{271}$ SILVA, Caio Mário Pereira da. Op. Cit. p128.

${ }^{272}$ Ibidem, p129.
} 
Destarte, não há de falar, outrossim, de incompatibilidade entre as regras de conexão da LArb e do art. $9^{\circ}$ da LINDB. O âmbito de aplicação é diverso, sendo a primeira especial, ao passo que a segunda, geral. Assim leciona Pedro Batista Martins, aduzindo que ambas as normas convivem sem qualquer conflito, uma vez que a norma geral é "estranha" aos contratos com cláusula arbitral:

"Não há que se pensar, tampouco, na disposição contida no art.
$9^{\circ}$ da LICC, pois estranha aos contratos submetidos à arbitragem.
A escolha da lei que vai ser adotada para solucionar a demanda
submetida à arbitragem não sofre qualquer limitação porventura
existente na Lei de Introdução. Na arbitragem as partes são livres
para exercerem a opção. A Lei de Introdução e a Lei de
Arbitragem, nesse particular, convivem sem qualquer
conflito."273

\title{
5.3 O alcance da autonomia da vontade: arbitragem interna e internacional
}

Questão que suscita debates entre a doutrina é se há alguma diferenciação entre a arbitragem comercial internacional e aquela interna, também chamada de doméstica. A pergunta se impõe, uma vez que respondida esta pergunta tem-se o âmbito de aplicação de diversas convenções que tratam da arbitragem internacional, ${ }^{274}$ bem como, no direito pátrio, a extensão da regra de conexão do art. $2^{\circ}, \S 1^{\circ}$ da LArb. Dolinger e Tiburcio explicam a importância deste exame:

\begin{abstract}
“A arbitragem pode ser doméstica, e ter uma determinada nacionalidade, ou ser considerada internacional ou transnacional. A nacionalidade da arbitragem é importante por três razões: 1) determina a lei que regula a arbitragem, que será, em princípio, a lei dessa nacionalidade; 2) determina o tribunal estatal que poderá vir a ter jurisdição sobre o processo arbitral, caso uma intervenção se faça necessária; e 3) identifica o procedimento a ser seguido para a execução do laudo arbitral, pois normalmente um laudo proferido internamente é mais facilmente executável do que um proferido alhures. Entretanto, a determinação da nacionalidade da arbitragem não questão simples: pode-se adotar o critério do lugar onde o tribunal arbitral tem a sua sede, o critério da proximidade, a nacionalidade ou domicílio das partes envolvidas, dentre outros. Muitos países recorrem ao critério que leva
\end{abstract}

\footnotetext{
${ }^{273}$ MARTINS, Pedro A. Batista. Op. Cit., p46.

274 “A distinção entre arbitragem interna e internacional reveste-se da maior importância em nosso ordenamento jurídico, já que tal diferenciação serve para delimitar o âmbito de aplicação de tratados e convenções internacionais que regem a arbitragem internacional."
} 
em conta a lei aplicável ao processo da arbitragem: caso seja aplicada norma não doméstica, a arbitragem é transnacional, internacional ou estrangeira. ${ }^{275}$

A Lei 9.307/1996, que em muito toma inspiração na Lei Modelo da UNCITRAL, apresenta algumas peculiaridades em comparação com esta. A principal delas é o critério utilizado pela LArb para definir a internacionalidade de uma arbitragem, contido no art. 34, parágrafo único, da referida Lei:

Art. 34 A sentença arbitral estrangeira será reconhecida ou executada no Brasil em conformidade com os tratados internacionais com eficácia no ordenamento interno e, na sua ausência, estritamente de acordo com os termos desta Lei.

Parágrafo único. Considera-se sentença arbitral estrangeira a que tenha sido proferida fora do território nacional. (grifamos)

Comumente, configuram como critérios utilizados pelo direito pátrio para determinar a internacionalidade de um contrato o local de sua celebração, a nacionalidade das partes convenentes, sua residência, domicílio ou sede, e ainda o local de execução do contrato. ${ }^{276}$ Contudo, pela leitura do texto legal, depreende-se que o critério utilizado para distinção entre arbitragens domésticas e internacionais é o da localidade da sentença proferida, e não a internacionalidade do contrato. Neste sentido, a Lei Brasileira divergiu amplamente da Lei Modelo da UNCITRAL ${ }^{277}$, que lhe inspirou, uma vez que esta segunda estabelece diversos critérios em seu art. $1^{\circ}$ para distinguir uma arbitragem como internacional.

\footnotetext{
${ }^{275}$ DOLINGER, Jacob e TIBURCIO, Carmen. Op. Cit., pp91-100. Os autores apontam que o critério da sede do tribunal arbitral foi adotado pelas leis de Dinamarca, Reino Unido, Suécia e alguns países árabes. Já o critério da nacionalidade ou domicílio das partes foi adotado pela Suíça, e subsidiariamente, Suécia e Reino Unido. Por outro lado, o critério da lei aplicada foi adotado por Alemanha, Grécia, Líbano e alguns casos decididos nos EUA.

${ }^{276}$ BAPTISTA, Luiz Olavo e MIRANDA, Sílvia Julio Bueno de. Op. Cit., p15.

${ }^{277}$ A Lei Modelo da UNCITRAL, art. $1^{\circ}$. (3) "Uma arbitragem é internacional se: (a) as partes numa convenção de arbitragem tiveram, no momento da conclusão desta Convenção, o seu estabelecimento em Estados diferentes; ou (b) um dos lugares a seguir referidos estiver situado fora do Estado no qual as partes têm seu estabelecimento: (1) o lugar da arbitragem, se estiver fixado na convenção de arbitragem ou for determinável de acordo com esta; (2) qualquer lugar onde deva ser executada uma parte substancial da obrigações resultantes da relação comercial ou o lugar com o qual o objeto do litígio se ache mais estreitamente conexo; ou (3) as partes tiverem convencionado expressamente que o objeto da convenção de arbitragem tem conexões com mais de um país"
} 
Destarte, visualiza-se, entre nós, o chamado critério geográfico para diferenciação entre arbitragens domésticas e estrangeiras. Doméstica será a arbitragem cuja sentença for proferida em território nacional; contrario sensu, internacional será aquela cuja sentença for proferida fora do território nacional.

\title{
Assim lecionam Jacob Dolinger e Carmen Tiburcio:
}

\begin{abstract}
“a legislação brasileira adota o critério geográfico, da sede do tribunal arbitral, em virtude da interpretação a contrario sensu do art. 34, § único, da Lei n. 9.307/96, que determina: 'considera-se sentença arbitral estrangeira a que tenha sido proferida fora do território nacional.' Portanto, se o tribunal arbitral tem sede no país, a sentença arbitral será doméstica e, consequentemente, essa será uma arbitragem interna, mesmo que envolva partes sediadas no exterior e objeto conectado ao exterior. ${ }^{278}$
\end{abstract}

Contudo, alguns doutrinadores defendem que a LArb diferenciou tão somente o conceito de sentença arbitral nacional e estrangeira, o que nas palavras de Fabiane Verçosa, "não se pode confundir, de forma alguma, com a distinção entre arbitragem interna e internacional." ${ }^{, 279}$ Posição esta adotada por diversos outros autores, tais como Clávio Valença Filho, ${ }^{280}$

\footnotetext{
${ }^{278}$ DOLINGER, Jacob e TIBURCIO, Carmen. Op. Cit., p92. Neste mesmo sentido, posiciona-se Maristela Basso: "O legislador pátrio não diferenciou as arbitragens internas e internacionais quanto aos seus efeitos, e sim quanto ao lugar onde foram proferidas, considerando como "internacionais" ou "estrangeiras" aquelas proferidas fora do território nacional. O critério, portanto, que determina o caráter internacional de uma decisão arbitral, segundo a Lei n. 9.307/96, é o 'lugar em que foi proferida'. (...) as arbitragens internacionais, isto é, aquelas que, à luz da Lei 9.307/96, têm suas decisões proferidas 'fora do território nacional' (...)" (BASSO, Maristela Apud VERÇOSA, Fabiane. "Arbitragem interna v. Arbitragem internacional: breves contornos da distinção e sua repercussão no ordenamento jurídico brasileiro face ao princípio da autonomia da vontade", In: TIBURCIO, Carmen e BARROSO, Luís Roberto (Coord.). Op. Cit. p427).

${ }^{279}$ VERÇOSA, Fabiane, Op. Cit., p425.

${ }^{280}$ Diz o autor: "É preciso, de início, deixar claro que a Lei de Arbitragem não distingue entre arbitragem internacional de arbitragem interna. (...) Esta distinção entre sentença nacional e sentença estrangeira que realiza a Lei de Arbitragem não pode ser confundida com a distinção entre arbitragem internacional e arbitragem interna, não assimilada por este diploma." Por conseguinte, Clávio Valença defende a adoção do critério econômico do fluxo e refluxo de capitais para determinação de uma arbitragem internacional, critério este também adotado hodiernamente na França. (VALENÇA FILHO, Clávio de Melo. "Aspectos de Direito Internacional Privado na arbitragem". In: Revista de Direito Bancário, do Mercado de Capitais e da Arbitragem. São Paulo: Revista dos Tribunais, v.7, 2000, pp386-387.)
} 


\title{
Rossani Garcez, ${ }^{281}$ Carlos Augusto Silveira Filho, ${ }^{282}$ Nadia de Araújo e Lauro Gama Jr., ${ }^{283}$ bem como João Bosco Lee, o qual aduz o seguinte:
}

\begin{abstract}
“(...) a nova Lei, a exemplo da lei holandesa de 1986 e da lei inglesa de 1996, não distingue arbitragem interna e arbitragem internacional. Ora, 'a distinção arbitragem interna/internacional constitui a summo divisio do direito da arbitragem' e a 'especificidade da arbitragem internacional não pode jamais ser totalmente eliminada'. Todavia, o nosso legislador considera que 'o que é bom para a arbitragem interna é bom para a arbitragem internacional, e vice-versa' e consagra um regime uniforme para todas as arbitragens". ${ }^{284}$
\end{abstract}

Com efeito, não obstante a discussão doutrinária acerca da adoção de algum critério outro para a distinção entre arbitragem doméstica e internacional, certo é que sob o regime da LArb, impõe-se o critério geográfico, tal como apontado por Tiburcio e outros, e que esta distinção não afeta a extensão da autonomia da vontade, que se aplica também às arbitragens domésticas. É a posição defendida por Dolinger e Tiburcio:

“observe-se, entretanto, que o Brasil, quanto à determinação da lei aplicável ao mérito (...) não distingue entre arbitragem interna e internacional, admitindo que as partes decidam sobre a lei aplicável mesmo na hipótese de arbitragem doméstica" 285

A pergunta que se impõe diante deste posicionamento é se às partes, numa arbitragem doméstica, sendo as mesmas brasileiras e com domicílio em território nacional, permite-se a adoção de lei estrangeira. Há diferentes

\footnotetext{
281 “A Lei n. 9.307/96, diferentemente da Lei Modelo, não contém uma definição sobre arbitragem internacional, apenas diferencia o laudo arbitral estrangeiro do nacional pela simples circunstância geográfica de sua emissão (...). O critério adotado por nossa lei é funcional e se encontra inserido em outras legislações arbitrais, como a italiana, mas não nos deve levar a engano quanto à definição mais ampla de arbitragem internacional, porque é claro que nesta outros fatores podem estar presentes, além dos geográficos" (GARCEZ, José Maria Rossani Apud MARTINS, Pedro A. Batista. Op. Cit. p356).

282 "Sob o ponto de vista da lei brasileira, não há propriamente arbitragem internacional; há sentença arbitral estrangeira." (LOBO, Carlos Augusto da Silveira. "Uma introdução à arbitragem internacional". In: ALMEIDA, Ricardo Ramalho (Coord.), "Arbitragem interna e internacional: questões de doutrina e da prática". Rio de Janeiro: Renovar, 2003, p8).

${ }^{283}$ ARAUJO, Nadia de., e SOUZA JR., Lauro da Game e. "A arbitragem internacional nos contextos interamericano e brasileiro". In: Revista Brasileira de Arbitragem, WALD, Arnoldo (Coord.), edição de lançamento, 2003, p80.

${ }^{284}$ LEE, João Bosco. "A Lei 9.307/96 e o direito aplicável ao mérito do litígio na arbitragem comercial internacional". In: Revista de Direito Bancário, do Mercado de Capitais e da Arbitragem. São Paulo: Revista dos Tribunais, v.11, 2001, p.348.

${ }^{285}$ DOLINGER, Jacob e TIBURCIO, Carmen. Op. Cit. p92.
} 
posicionamentos doutrinários acerca do tema, podendo ser observadas duas grandes posições: a) permissão ampla e irrestrita da adoção de lei estrangeira em arbitragens internas; e b) proibição, pela distinção entre arbitragem interna e internacional, i.e., deve haver algum elemento que justifique a aplicação do direito alienígena.

A primeira corrente, cujo entendimento é a permissão legal ampla para adoção é defendida por diversos autores. Pedro Batista Martins em análise arguta, aduz que se o legislador permite a aplicação de direito anacional, quanto mais um direito estrangeiro, uma vez que, quem pode mais, pode o menos:

"Creio que o grau de liberdade conferido pelo comando do $\S 1^{\circ}$, do art. $2^{\circ}$ da Lei de Arbitragem, é dos mais elevados. Permite um alcance amplo de interpretação a ponto de afastar o ordenamento jurídico interno em prol de outro escolhido livremente pelas partes. (...) Se a arbitragem pode afastar o direito posto e ser de equidade, a critério das partes, logicamente, poderá, tão-só, ser de direito aplicando-se outro ordenamento que não o interno." (grifo no original) $^{286}$

Jacob Dolinger e Carmen Tiburcio, também adotam esta corrente:

"No caso do Brasil, numa arbitragem meramente interna, envolvendo partes brasileiras, aqui domiciliadas, e relativamente a contrato celebrado e com execução no Brasil, ainda assim pode ser regulada por uma lei estrangeira, se essa for a vontade das partes." 287

Luiz Olavo Baptista e Sílvia Julio de Bueno Miranda, em lição extremamente didática sobre assunto, também mostram-se favoráveis à adoção de lei estrangeira em contratos internos, sem elemento algum de estraneidade:

"A autonomia da vontade das partes concedida pela lei de arbitragem não sofre nenhuma limitação nos contratos domésticos. Ela é tão ampla na arbitragem, que autoriza as partes

\footnotetext{
${ }^{286}$ MARTINS, Pedro A. Batista. Op. Cit. pp46-47.

287 "No caso do Brasil, numa arbitragem meramente interna, envolvendo partes brasileiras, aqui domiciliadas, e relativamente a contrato celebrado e com execução no Brasil, ainda assim pode ser regulada por uma lei estrangeira, se essa for a vontade das partes." (DOLINGER, Jacob e TIBURCIO, Carmen. Op. Cit., p97).
} 
em um contrato doméstico a escolherem uma lei estrangeira para governá-lo, o que tem sido considerado uma real revolução no direito brasileiro. Essa inovação está em consonância com sua opção por não diferenciar as arbitragens domésticas das arbitragens internacionais: em ambos os casos as partes são livres para escolher a lei aplicável. Para a nossa Lei de Arbitragem, a lei escolhida pelas partes será a lei aplicável sem discussão ou exame de qualquer lei de conflito. É possível dizer que a lei de conflito aplicável é 'o árbitro deverá aplicar a lei escolhida pelas partes'. De fato, se as partes em uma convenção de arbitragem podem afastar a legislação nacional e confiar o contrato a uma lei 'a-nacional', em princípios gerais de direito, costumes e regras internacionais de comércio, lex mercatoria e ex aequo et bono, não haveria razão alguma para proibi-las de eleger uma lei estrangeira. Dessa forma, se as partes assim escolherem, uma arbitragem envolvendo partes brasileiras e um contrato executado no Brasil poderá ser submetida a uma lei estrangeira."

\title{
Nadia de Araujo também filia-se aos defensores desta posição:
}

"E, ao menos com relação ao direito pátrio, houve um grande progresso recentemente, com a introdução no ordenamento jurídico brasileiro da liberdade de escolha da lei aplicável através da Lei 9.307/96 sobre arbitragem, mostrando que o Brasil passa a aceitar o princípio da vontade maiores vacilações. Sua incorporação no sistema nacional aumentou, inclusive, seu campo de incidência, pois agora permitir-se-á a autonomia da vontade não só para os contratos internacionais, como também para os contratos internos, sempre que houver convenção de arbitragem" 288

\section{Outrossim, Maurício Gomm Ferreira dos Santos aponta a clareza da}

LArb em comparação com as leis de Argentina, Paraguai e Uruguai, que

não possuem regra clara sobre a lei aplicável ao mérito das disputas:

\begin{abstract}
"Os estatutos da Argentina, Paraguai e Uruguai, dentre outros, não possuem uma regra clara sobre qual seria a regra legal aplicável ao mérito da disputa, enquanto a arbitragem brasileira estabelece o mesmo tipo de regra que pode ser aplicável tanto para arbitragens domésticas como internacionais. Isto é o que pode ser inferido do art. $2^{\circ}$ da Lei $9.307 / 96$ (...),289
\end{abstract}

Se a primeira corrente apoia a possibilidade de adoção de lei estrangeria em arbitragens domésticas sem maiores problemas, a segunda

\footnotetext{
${ }^{288}$ ARAUJO, Nadia de. Op. Cit. pp206-207.

${ }^{289}$ SANTOS, Maurício Gomm Ferreira dos. "A situação dos países da América Latina no que tange à lei aplicável ao mérito do litígio submetido a uma arbitragem comercial internacional". In: Revista de Arbitragem e Mediação, WALD, Arnoldo (Coord.), n. 2, 2004, p104.
} 
corrente entende pela impossibilidade, havendo a lei estrangeira de ser aplicada tão somente às arbitragens internacionais. Contrario sensu, aplicase às arbitragens internas a lei brasileira. Esta posição é defendida por João Bosco Lee:

\begin{abstract}
"o reconhecimento da autonomia da vontade é certamente uma revolução no direito internacional privado brasileiro e era mesmo imperativo que para que a lei de arbitragem fosse eficaz, mas a sua extensão à arbitragem interna é 'excessiva e descabida'. À arbitragem interna se impõe o direito interno.",290
\end{abstract}

Da mesma forma Paulo Borba Casella, que se pronuncia contrário à aplicação, mas reconhece que a mesma é permitida pelo legislador:

\begin{abstract}
“a lei brasileira não faz distinção de regime legal entre a arbitragem interna e a internacional. Teria, conduto, adiantandose excessivamente o novo diploma legal, instaurando diversidade de regência legal, conforme se trate de cláusula arbitral ou de eleição de foro judicial, mesmo em contratos regidos pelo direito interno? Isso poderia se afigurar excessivo e descabido."291
\end{abstract}

Igualmente, Fabiane Verçosa expõe sua posição contrária à aplicação da lei estrangeira em arbitragens internas:

\begin{abstract}
"em vista de todo o exposto, partilhamos da opinião de que a autonomia conferida às partes para escolherem o direito aplicável à arbitragem, tal como prevista no art. $2^{\circ}, \S 1^{\circ}$, da Lei n. 9.307/96, está circunscrita às arbitragens internacionais, não se estendendo às arbitragens internas." 292
\end{abstract}

Por fim, trazemos a lição de Ricardo Ramalho Almeida, que após discorrer sobre a ausência de distinção legal entre arbitragem interna e internacional, entende parecer artificial e até, em alguns casos, fraudulenta a aplicação de lei alienígena à arbitragens internas:
"nas arbitragens internas, sem qualquer elemento de estraneidade, o direito nacional é naturalmente chamado a se aplicar, parecendo artificial (e podendo até mesmo ser fraudulento) as partes invocarem, para suprir as lacunas de sua manifestação de vontade, os padrões, critérios, tipos legais e

\footnotetext{
${ }^{290}$ LEE, João Bosco. Op. Cit., p355.

${ }^{291}$ CASELLA, Paulo Borba. "Autonomia da vontade, arbitragem comercial internacional e direito brasileiro”. In: TIBURCIO, Carmen e BARROSO, Luís Roberto (Orgs.). Op. Cit., p741.

${ }^{292}$ VERÇOSA, Fabiane. Op. Cit., p441.
} 
regras jurídicas cogentes e supletivas de outro ordenamento jurídico, que não o brasileiro. Inobstante gozarem as partes da prerrogativa da autonomia privada, que lhes permite pactuar cláusulas e condições negociais que entenderem pertinentes, devem necessariamente conformar-se aos limites da liberdade de contratar, tal como compreendida no direito nacional, isto é, deverão respeitar o que se convencionou chamar de ordem pública interna, por oposição à ordem pública internacional, sendo certo que a primeira é mais restritiva e exigente que a segunda. Assim, onde não existe conflito de leis, não se vê muito bem o propósito lícito de submeter a um direito de origem estrangeira ou internacional determinada relação jurídica de âmbito exclusivamente nacional, em que todos os elementos de conexão apontem para o direito brasileiro como único relevante para sua regência.",293

Contudo, o próprio autor levanta hipótese em que seria, em sua opinião, justificável, excepcionalmente, a adoção de lei estrangeira para reger um contrato interno: quando esta escolha não for arbitrária, isto é, quando houver algum elemento que razoavelmente fundamente essa escolha, além da proibição de fraude à lei. O próprio autor exemplifica seu argumento: um contrato interno acessório a um contrato internacional, ou que diga respeito à operação internacional. ${ }^{294}$

Situação curiosa trazida pela LArb é a ausência de disposição sobre como proceder diante da falta de escolha das partes acerca da lei aplicável. Permitiu o legislador, conforme demonstrado, a ampla autonomia na escolha da lei, contudo, como proceder diante do silêncio dos convenentes? A base da questão é se o árbitro deve agir da mesma forma que o juiz estatal agiria, e portanto, recorrendo às regras de conexão da lex fori ou ser totalmente independente.

A primeira hipótese (aplicação das regras de conexão do país em que a arbitragem está em curso) foi a posição primeiramente adotada pela comunidade internacional. Contudo, a lei francesa de arbitragem, datada de 1981, trouxe importante alteração: diante da ausência de lei escolhida pelas partes, cabe ao árbitro fazer tal escolha, sem referência a qualquer regra de

\footnotetext{
${ }^{293}$ ALMEIDA, Ricardo Ramalho. Op. Cit., p158-159.

${ }^{294}$ Ibidem, p161.
} 
conexão, consagrando, assim, a segunda hipótese. Essa tendência foi seguida pelas câmaras arbitrais mais renomadas, tais como a CCI e AAA. ${ }^{295}$

\subsection{Autonomia e o limite da ordem pública}

A autonomia das partes encontra seu maior limitador nas chamadas normas de ordem pública, cuja noção é deveras complexa. ${ }^{296}$ Tais normas possuem uma diferente aplicação quando se trata do plano interno, em que atuam como princípio limitador dos pactos e vontade dos particulares, cuja liberdade não é admitida em específicas áreas da vida privada, ${ }^{297}$ ou em âmbito internacional, configurando a ordem pública como princípio limitador de fenômenos jurídicos alienígenas no plano interno, consubstanciando, assim, um freio à autonomia. ${ }^{298}$

A LArb prevê expressamente como limite à autonomia das partes os bons costumes e a ordem pública, previsão ímpar no direito comparado, ${ }^{299}$ em seu art. $2^{\circ}, \S 1^{\circ}$. Trazemos novamente o teor da norma:

Art. $2^{\circ} \mathrm{A}$ arbitragem poderá ser de direito ou equidade, a critério das partes.

$\S 1^{\circ}$ Poderão as partes escolher, livremente, as regras de direito que serão aplicadas na arbitragem, desde que não haja violação aos bons costumes e à ordem pública.

$\S 2^{\circ}$ Poderão, também, as partes convencionar que a arbitragem se realize com base nos princípios gerais de direito, nos usos e costumes e nas regras internacionais de comércio. (grifamos)

\footnotetext{
${ }^{295}$ DOLINGER, Jacob e TIBURCIO, Carmen. Op. Cit., pp98-101.

${ }^{296}$ Segundo Jacob Dolinger, o conceito de ordem pública "é de natureza filosófica, moral, relativa, alterável e, portanto, indefinível". Prossegue o autor dizendo que "a ordem pública encerra, assim, os planos filosófico, político, moral e econômico de todo Estado constituído."

${ }^{297}$ DOLINGER, Jacob. Op. Cit., p393. O autor cita o brocardo romano privatorum convetio juri publico non derrogat.

${ }^{298}$ Neste sentido, ensina Ricardo Ramalho Almeida: “em qualquer das perspectivas, seja a do direito civil (...), seja a do direito internacional (...), incide a ordem pública como contraponto à liberdade contratual, no plano interno, e à liberdade de escolha das regras aplicáveis, no plano internacional. A liberdade proporcionada pela autonomia da vontade, ou autonomia privada, é exercida no interior do espaço que a ela é deixado pelo princípio da prevalência dos interesses públicos, gerais e coletivos, sobre os interesses privados, particulares e individuais. A noção de ordem pública atua, assim, como um freio necessário à liberdade, em consideração à interesses que têm prioridade axiológica e normativa sobre a autonomia dos particulares" (ALMEIDA, Ricardo Ramalho. Op. Cit., p24).

${ }^{299}$ Ibidem, p167.
} 
Convencionou-se na doutrina apontar diferentes níveis de funcionamento da ordem pública. Neste sentido, Jacob Dolinger aponta três graus:

\begin{abstract}
"assim, identificar-se-ia por primeiro grau de ordem pública aquele de âmbito interno, que estabelece, v.g., a invalidade de cláusulas contratuais que firam princípios basilares do ordenamento jurídico; o segundo grau designaria a ordem pública de direito internacional privado, que é aquela que impede a aceitação de leis, atos e decisões estrangeiros contrários à ordem pública interna e, consequentemente, produz efeitos no plano internacional. O terceiro grau de ordem pública é o que estabelece os princípios universais, nos vários setores do direito internacional, bem como nas relações internacionais, servindo aos mais altos interesses da comunidade mundial, às aspirações comuns da Humanidade. Trata-se de uma ordem de valores situada acima dos sistemas jurídicos internos, que, eventualmente, poderá estar até mesmo em colisão com interesses circunstanciais das nações individualmente consideradas." 300
\end{abstract}

Destarte, em plano interno a ordem pública atuará como garantidora do império de determinadas normas, sendo vedada sua inobservância pelas partes, ainda que esta inobservância seja fruto de sua autonomia. São normas, contudo, de escopo reduzido: tratam de proteção aos menores, incapazes, à economia nacional e à dignidade da pessoa humana. Neste sentido, ensina Izabel de Albuquerque Pereira:

\begin{abstract}
“a escolha da lei aplicável à substância da disputa arbitral não poderá, por conseguinte, ofender aqueles preceitos e valores basilares de uma sociedade, indispensáveis à manutenção de sua ordem moral, jurídica, política e econômica. Muitas vezes tal ofensa é de difícil percepção, pois nem sempre será compreendida no momento da escolha das normas que regerá a arbitragem, mas tão somente quando da sua efetiva aplicação ao caso concreto. Tal aferição competirá ao árbitro, juiz de fato e de direito, o qual afastará qualquer disposição presente na lei estrangeira que ofenda a ordem pública." ${ }^{301}$
\end{abstract}

Salienta ainda a autora que não apenas a ordem pública do foro em que a sentença arbitral será executada, mas também daqueles países que

\footnotetext{
${ }^{300}$ DOLINGER, Jacob. “Ordem pública mundial: ordem pública verdadeiramente internacional no direito internacional privado". In: Revista de Informação Legislativa, vol. 23, n.90, 1986, p211.

${ }^{301}$ PEREIRA, Izabel Albuquerque. "Ordem pública nas arbitragens comerciais internacionais". In: BARROSO, Luís Roberto e TIBURCIO, Carmen. Op. Cit., p523.
} 
tenham algum tipo de conexão com o caso, bem como suas regras imperativas. $^{302}$

Questão que se impõe é acerca da vinculação da norma de ordem pública. Em outras palavras, sendo as normas de ordem pública diferentes em relação a cada ordenamento jurídico, a quais normas a parte está vinculada? Esta questão se dá pela opção feita pelo legislador como critério definidor de arbitragens internas e internacionais o dito critério geográfico, qual seja, arbitragens internas são aquelas cuja sentença é aqui proferida, ao passo que internacionais são aqueles cujo laudo seja proferido alhures. Supondo uma arbitragem com partes estrangeiras, advinda de contrato internacional, prevendo obrigações não executadas no Brasil, com lei de regência estrangeira, contudo, tendo sua sede em solo brasileiro. Diante disso, pergunta-se: haveria algum dever de observância da ordem pública brasileira nesta arbitragem? A resposta afirmativa parece forçosa e inadequada. Situação diferente, contudo, é quando uma dada arbitragem trata de contrato brasileiro, ou com partes brasileiras, ou de contrato executado em território brasileiro. Nesta hipótese, há elementos de contato com o ordenamento brasileiro, sendo, portanto, necessária a observância das normas de ordem pública brasileira, ainda que seja uma arbitragem cuja sede seja em país estrangeiro. Neste mesmo sentido, posiciona-se Ricardo Ramalho Almeida:

\footnotetext{
"cumpre notar, a esse respeito, que, na concretização do princípio de respeito à ordem pública e aos bons costumes, exigido pelo $\S 1^{\circ}$ do artigo $2^{\circ}$ da Lei, na perspectiva dupla e concorrente competência que prevalece na matéria - isto é, seja na aplicação do direito à solução do litígio pelo árbitro, seja no eventual exame posterior da sentença arbitral pelo juiz estatal -, a intensidade das exigências relacionadas a esse dispositivo será diretamente proporcional à intensidade da conexão da causa com o país (...)" (grifo no original $)^{303}$
}

\footnotetext{
${ }^{302}$ Ibidem, p524. Neste sentido, pode-se citar, como ilustração, a aplicação da regra imperativa de curso forçado do Real. Para qualquer contrato a ser executado no Brasil, ainda que tenha lei estrangeira e cláusula de arbitragem, é vedada a previsão de pagamento em ouro ou moeda estrangeira que não o Real, de acordo com a norma imperativa contida no Decreto-lei n. 857/1969. ${ }^{303}$ ALMEIDA, Ricardo Ramalho. Op. Cit., p170.
} 
Segundo lição de Ricardo Ramalho Almeida, a consequência dessa violação, ainda que não expressa na LArb, será a ineficácia do direito escolhido. ${ }^{304}$ Mister a observância de normas imperativas constantes do ordenamento escolhido para reger a controvérsia, bem como do país em que a sentença arbitral for executada. ${ }^{305}$

De complexa incidência é o terceiro grau de ordem pública em arbitragens ditas verdadeiramente internacionais (em que pese a LArb não fazer distinção sobre a matéria do conflito, e sim pelo critério geográfico). Dolinger e Tiburcio defendem a não aplicação de um norma nacional quando esta for considerada "empecilho ao comércio internacional", prejudicando o fluxo de comércio mundial. ${ }^{306}$

Por fim, há de se perquirir se há hipótese de fraude à lei ou law shopping na escolha da lei aplicável. Na lição de Paulo Henrique Gonçalves Portela, fraude à lei consiste: "em ação deliberada, voltada a evitar a aplicação de uma norma sobre determinado caso concreto., 307

Em matéria contratual, a fraude à lei é chamada de law shopping, que na lição de Jacob Dolinger consiste:

\footnotetext{
“(...) por meio de um ardil que denominamos legal shopping ou law shopping, ocorrem hipóteses em que uma parte desloca, deliberadamente, o centro de gravidade de uma relação jurídica, de sua sede natural para outra localidade, com o exclusivo objetivo de subtrairse à lei normalmente aplicável, e colocar-se ao abrigo da lei da jurisdição por ele escolhida"308
}

Prossegue o autor, contudo, explicitando que em sede de contratos internacionais, não há de se falar em fraude à lei, por estarem ao abrigo da autonomia dos convenentes para submeterem o negócio à lei que melhor

\footnotetext{
${ }^{304}$ Ibidem, p163.

${ }^{305}$ DOLINGER, Jacob e TIBURCIO, Carmen. Op. Cit., p105.

${ }^{306}$ Ibidem, p108.

${ }^{307}$ PORTELA, Paulo Henrique Gonçalves. “Direito Internacional Público e Privado”. Salvador: JusPodivm. $4^{\text {a }}$ ed., 2012, p.657.

${ }^{308}$ DOLINGER, Jacob. Op. Cit., nota na p441.
} 
lhes aprouver. ${ }^{309}$ De modo contrário, alguns autores defendem a existência de law shopping quando não há qualquer tipo de vínculo estreito entre o contrato e a lei escolhida, ou então, quando lei estrangeira rege contrato meramente interno. ${ }^{310}$

Contudo, há de se ter em mente que a LArb não fez distinção entre arbitragens internas e internacionais, estendo a autonomia da escolha do direito aplicável também às arbitragens internas. Ora, esta permissão é legal, não havendo óbice algum nesta manobra jurídica. 


\section{Conclusão}

Diante do que foi tratado ao longo de nossa análise, verifica-se o forte impacto que o instituto da arbitragem confere à autonomia privada. Com efeito, tem-se na arbitragem a consagração do auto-regramento dos particulares em matéria de resolução de conflitos, inclusive em aspectos materiais do contrato, caso tenham optado as partes pela via arbitral. Destarte, pode-se atestar:

1 - No plano interno, antes de consubstanciar-se em limitação da vontade particular, o paradigma contratual hodierno qualifica a vontade das partes, tutelando a relação de colaboração entre elas para evitar possíveis abusos na expressão da autonomia.

2 - Neste sentido, tem-se uma importante ferramenta pró-arbitragem a proibição do venire contra factum proprium, decorrência direta da cláusula geral de boa-fé insculpida no art. 422 do Código Civil. Uma vez demonstrada a vontade em furtar-se à via judicial através da cláusula de arbitragem livremente pactuada entre as partes, viola positivamente o contrato aquela que lança mão de medidas protelatórias anti-arbitragem, voltando atrás em sua própria vontade.

3 - Incorre igualmente em comportamento contraditório o convenente que firmou cláusula compromissória, ainda que dita vazia, e abusa da vontade ao não mais querer completa-la em juízo. Assim o é pois às partes incide um dever de colaboração no sentido de fazer completa a cláusula.

4 - Decorrentes também da cláusula da boa-fé, os ditos deveres laterais impostos aos convenentes labutam para a qualificação da vontade na relação de colaboração. Diante disso, viola o dever de confidencialidade, inerente ao processo arbitral, a parte que expõe publicamente a existência 
do litígio, fato este que caso demonstrado o dano sofrido pela parte exposta, incorrerá a faltante em dever de reparação, seja material, seja moral.

5 - No plano do DIPr, tem-se a consagração da autonomia da vontade das partes na escolha da lei aplicável aos contratos, superando, assim, uma enorme polêmica entre nós.

6 - Nos contratos com cláusula de arbitragem, afasta-se o art. $9^{\circ}$ da Lei de Introdução e sua regra de conexão, sendo permitida às partes a adoção de qualquer direito aos contratos, sendo este estrangeiro, princípios gerais, lex mercatoria, equidade ou ainda, direito totalmente anacional, como os Princípios do UNIDROIT.

7 - Nota-se também uma extensão desse grande poder de escolha às arbitragens internas, ainda que não haja elemento algum de estraneidade nelas, uma vez que a LArb lança mão do critério geográfico para distinção entre arbitragens internas e internacionais, e ainda assim, reputa às duas o mesmo regramento na escolha do direito aplicável. Neste sentido, abre-se às partes a adoção de lei estrangeira para regular contrato interno, respeitandose sempre o limite da ordem pública. 


\section{Bibliografia}

ALMEIDA, Ricardo Ramalho. "Arbitragem comercial internacional e ordem pública”. Rio de Janeiro: Renovar, 2005.

,. "Arbitragem interna e internacional: questões de doutrina e da prática". Rio de Janeiro: Renovar, 2003.

AMORIM, Edgar Carlos de, "Direito Internacional Privado", Rio de Janeiro: Forense, 2005.

ALVIM, J. E. Carreira, "Tratado Geral da Arbitragem". Belo Horizonte: Mandamentos, 2000.

ARAUJO, Nadia de, "Contratos Internacionais: autonomia da vontade, MERCOSUL e convenções internacionais". Rio de Janeiro: Renovar, $4^{\mathrm{a}}$ ed., 2009.

AZEVEDO, Fábio de Oliveira, "Direito Civil: introdução e teoria geral". Rio de Janeiro: Lumen Juris, 2a ed., 2009.

BAPTISTA, Luiz Olavo e MIRANDA, Sílvia Julio Bueno de., "Convenção de arbitragem e escolha da lei aplicável: uma perspectiva do direito brasileiro", In: Revista de Arbitragem e Mediação, WALD, Arnoldo (Coord.). São Paulo: Revista dos Tribunais, n. 27, outubro-dezembro, 2010.

BAPTISTA, Luiz Olavo, “Dos contratos internacionais: uma visão teórica e prática", São Paulo: Saraiva, 1994.

BARROSO, Carlos Roberto, "Curso de direito constitucional contemporâneo: os princípios fundamentais e a construção do novo modelo". São Paulo: Ed. Saraiva, 2009.

, "Temas de Direito Constitucional", tomo I. Rio de Janeiro:

Renovar, 2001. 
BERMUDES, Sérgio, "Introdução ao Processo Civil". Rio de Janeiro: Forense, $4^{\mathrm{a}}$ ed., 2006.

BEVILAQUA, Clóvis, "Princípios elementares de direito internacional privado". Rio de Janeiro: Freitas Bastos, $2^{\mathrm{a}}$ ed., 1934.

BOBBIO, Norberto. "Teoria Geral do Direito”. São Paulo: Martins Fontes, 2008, 321p.

CÂMARA, Alexandre Freitas, “Arbitragem”. Rio de Janeiro: Lumen Juris, 4a ed., 2005.

CARMONA, Carlos Alberto, “Arbitragem e Processo - Um comentário à Lei n. 9.307/96”. São Paulo: Atlas, $2^{a}$ ed., 2004.

CASTRO, Amilcar de, "Direito Internacional Privado". Rio de Janeiro: Forense, 5a ed., 2004.

CRETELLA JÚNIOR, José, "Curso de direito romano: o direito romano e o direito civil brasileiro no Novo Código Civil". Rio de Janeiro: Forense, $30^{\mathrm{a}}$ ed., 2007.

CRETELLA NETO, José, "Curso de Arbitragem: arbitragem comercial, arbitragem internacional, lei brasileira de arbitragem, direito privado brasileiro aplicado à arbitragem, convenções internas". Rio de Janeiro: Forense, 2004.

DEL'OLMO, Florisbal de Souza, “Direito Internacional Privado: abordagens fundamentais, legislação, jurisprudência". Rio de Janeiro: Forense, $4^{\mathrm{a}}$ ed., 2004.

DIDIER JR., Fredie, "Curso de Direito Processual Civil", volume I. Salvador: JusPodivm, $11^{\mathrm{a}}$ ed., 2009. 
DINIZ, Maria Helena, "Lei de introdução ao Código Civil interpretada", São Paulo: Saraiva, 4a ed., 1998.

DI PIETRO, Maria Sylvia Z., "Parcerias na Administração Pública", São Paulo: Atlas, 2002.

DOLINGER, Jacob e TIBURCIO, Carmen, "Direito Internacional Privado: arbitragem comercial internacional”. Rio de Janeiro: Renovar, 2003.

DOLINGER, Jacob, "Direito Internacional Privado: parte geral", Rio de Janeiro: Renovar, 9a ed., 2008.

FOUCHARD, Phillipe; GAILLARD, Emmanuel; GOLDMAN, Bertold. "Fouchard Gaillard Goldman on international arbitration", Haia: Kluwer Law International, 1999.

FREITAS, Teixeira A., "Esboço", Rio de Janeiro: Ministerio da Justiça e Negocios Interiores, 1952.

GARCEZ, José Maria Rossani (Coord.), "Arbitragem na era da globalização”. Rio de Janeiro: Forense, 2a ed., 1999.

GONÇALVES, Carlos Roberto, "Direito Civil Brasileiro", volume III. São Paulo: Saraiva, 6a ed., 2009.

GORDLEY, James, "The philosofical origins of Modern Contract Doctrine", Oxford: Clarendon Press, 1992.

HOBSBAWM, Eric, “A era das revoluções: 1789 - 1848”, São Paulo: Paz e Terra, 25a ed., 2010.

JOHNSTON, Robert, "Party autonomy in contracts specifying foreign law", In: William \& Mary Law Review, vol. 7, No. 37, 1966. 
LEE, João Bosco. "A Lei 9.307/96 e o direito aplicável ao mérito do litígio na arbitragem comercial internacional”. In: Revista de Direito Bancário, do Mercado de Capitais e da Arbitragem. São Paulo: Revista dos Tribunais, v.11, 2001.

LEMES, Selma Ferreira, "Principios e origens da Lei de Arbitragem" In: Revista do Advogado, n. 51, 1997 , "O Desenvolvimento da Arbitragem no Brasil e no exterior". In: Revista Vasca de Derecho Procesal y Arbitraje, Universidad del Pais Vasco, 2005, tomo XVII

LOPES, Miguel Serpa, "Curso de Direito Civil". Rio de Janeiro: Freitas Bastos, 6a ed., 1996.

MARINONI, Luiz Guilherme, "Teoria Geral do Processo", volume I. São Paulo: RT, 2006.

MARTINS-COSTA, Judith, "A boa-fé no Direito Privado". São Paulo: Revista dos Tribunais, 2000.

MARTINS, Pedro A. Batista, "Apontamentos sobre a Lei de Arbitragem: comentários à Lei 9.307/1996”. Rio de Janeiro: Forense, 2008

MARTINS, Pedro A. Batista e GARCEZ, José Maria Rossani (coord.), "Reflexões sobre Arbitragem, in memoriam do Desembargador Cláudio Vianna de Lima”. São Paulo: LTr, 2002.

MEIRELES, Rose Melo Vencelau. "Autonomia privada e dignidade humana”. Rio de Janeiro: Renovar, 2009.

MENDES, Gilmar Ferreira; COELHO, Inocêncio Mártires; BRANCO, Paulo Gustavo Gonet. "Curso de Direito Constitucional". São Paulo: Saraiva, $2^{a}$ ed., 2008. 
MENEZES, Wagner (Org.), "O direito internacional e o direito brasileiro: homenagem a José Francisco Rezek”. Ijuí: Unijuí, 2004.

MITIDIERO, Daniel Francisco. "Elementos para uma teoria contemporânea do processo civil brasileiro". Porto Alegre: Livraria do Advogado, 2005

MORAES, Maria Celina Bodin de. (Org.). "Princípios do direito civil contemporâneo". Rio de Janeiro: Renovar, 2006.

, "Na medida da pessoa humana". Rio de Janeiro: Renovar, 2010.

MOROSINI, Fábio, "Globalização e Direito: além da metodologia tradicional dos estudos jurídicos comparados a um exemplo do Direito Internacional Privado", In: Revista de informação legislativa, v.43, n. 172, outubro/dezembro de 2006

NEGREIROS, Teresa. "Teoria do contrato: novos paradigmas". Rio de Janeiro: Renovar, 2006, 2a ed.

PEIXINHO, Manoel Messias; GUERRA, Isabella Franco; NASCIMENTO FILHO, Firly. (Orgs.) "Os princípios da Constituição de 1988". Rio de Janeiro: Lumen Juris, 2001.

PEREIRA, Caio Mário da Silva, "Instituições de Direito Civil", volume III. Rio de Janeiro: Forense, 12a ed., 2007. , "Instituições de Direito Civil", volume I. Rio de Janeiro: Forense, 21a ed., 2005.

PERLINGIERI, Pietro. "Perfis de Direito Civil". Rio de Janeiro: Renovar, 1997. 
PINTO, José Emílio Nunes. "A Cláusula compromissória à luz do Código Civil". In: Revista de Arbitragem e Mediação, WALD, Arnoldo (Coord.), 2005 , volume 4.

PORTELA, Paulo Henrique Gonçalves. "Direito Internacional Público e Privado”. Salvador: JusPodivm. $4^{\mathrm{a}}$ ed., 2012.

RAMOS, Carmem Lúcia Silveira (org.) et al, "Diálogos sobre direito civil", Rio de Janeiro: Renovar, 2002.

RICHMAN, William, M. E RILEY, David, "The First Restatement of Conflict of Laws on the Twenty-fifth anniversary of its sucessor: contemporary practice in tradicional courts", In: Maryland Law Review, Vol. 56, 1997.

RODAS, João Grandino (coord.) et al. "Contratos internacionais", São Paulo: Revista dos Tribunais, $3^{\text {a }}$ ed., 2002.

SAMTLEBEN, Jürgen, "Teixeira de Freitas e a autonomia das partes no direito internacional privado latino-americano", In: Revista de Informação Legislativa, no. 85, 1985.

SANTOS, Maurício Gomm Ferreira dos. "A situação dos países da América Latina no que tange à lei aplicável ao mérito do litígio submetido a uma arbitragem comercial internacional". In: Revista de Arbitragem e Mediação, WALD, Arnoldo (Coord.), n. 2, 2004.

SILVA, José Afonso da, "Curso de Direito Constitucional Positivo". São Paulo: Malheiros, $26^{\mathrm{a}}$ ed., 2006.

SOUZA JR., Lauro Gama, "Contratos internacionais à luz dos princípios do UNIDROIT 2004: Soft Law, Arbitragem e Jurisdição", Rio de Janeiro: Renovar, 2006. 
SOUZA E SILVA, Luiz Alberto de, "Direito Internacional Privado: Lei de Introdução ao Código Civil”. Rio de Janeiro: Lumen Juris, 2000.

STRENGER, Irineu, "Direito do comércio internacional e lex mercatoria". São Paulo: LTr, 1996. , “Direito Internacional Privado”, São Paulo: LTr, 6a ed., 2005

TEPEDINO, Gustavo; BARBOZA, Heloisa Helena; MORAES, Maria Celina Bodin de (Orgs.). "Código civil interpretado conforme a Constituição da República". Rio de Janeiro: Renovar, volume II, 2006.

TEPEDINO, Gustavo, "Temas de Direito Civil", tomo I. Rio de Janeiro: Renovar, $3^{\mathrm{a}}$ ed., 2004. , "Temas de Direito Civil", tomo II. Rio de Janeiro: Renovar, 2004.

TIBURCIO, Carmen e BARROSO, Luís Roberto (Org.) " $O$ direito internacional contemporâneo: estudos em homenagem ao professor Jacob Dolinger". Rio de Janeiro: Renovar, 2006.

VALENÇA FILHO, Clávio de Melo. “Aspectos de Direito Internacional Privado na arbitragem”. In: Revista de Direito Bancário, do Mercado de Capitais e da Arbitragem. São Paulo: Revista dos Tribunais, v.7, 2000

WALD, Arnoldo, “Obrigações e Contratos". São Paulo: Saraiva, 16a ed., 2004

, "Novos rumos para a arbitragem no Brasil", Revista de Direito Bancário, do Mercado de Capitais e da Arbitragem. São Paulo: Revista dos Tribunais, no. 14, out./dez., 2001

WEBER, Max, "Economia e Sociedade: fundamentos da sociologia compreensiva”. São Paulo: Editora UnB/Imprensa Oficial, 4a ed., 2004. 
WIEACKER, Franz, "História do Direito Privado Moderno", trad. Por A. M. Botelho Hespanha. Lisboa: Fundação Calouste Gulbenkian, 3a ed., 2004. 